ISABELA UGO LUQUES

\title{
ESTRUTURA E ULTRAESTRUTURA DA JUNÇÃO MIOTENDÍNEA DO MÚSCULO PTERIGÓIDEO MEDIAL DE RATOS WISTAR COM ENVELHECIMENTO.
}

Dissertação apresentada ao Programa de Pós-Graduação em Ciências Morfofuncionais do Instituto de Ciências Biomédicas da Universidade de São Paulo, para obtenção do Título de Mestre em Ciências.

São Paulo

2009 
ISABELA UGO LUQUES

\section{ESTRUTURA E ULTRAESTRUTURA DA JUNÇÃO MIOTENDÍNEA DO MÚSCULO PTERIGÓIDEO MEDIAL DE RATOS WISTAR COM ENVELHECIMENTO}

Dissertação apresentada ao Programa de Pós-Graduação em Ciências Morfofuncionais do Instituto de Ciências Biomédicas da Universidade de São Paulo, para obtenção do Título de Mestre em Ciências.

Area de Concentração: Ciências Morfofuncionais

Orientador: Prof. Dr. li-Sei Watanabe

São Paulo

2009 
DADOS DE CATALOGAÇÃO NA PUBLICAÇÃO (CIP)

Serviço de Biblioteca e Informação Biomédica do

Instituto de Ciências Biomédicas da Universidade de São Paulo

(c) reprodução total

Luques, Isabela Ugo.

Estrutura e ultraestrutura da junção miotendínea do músculo pterigóideo medial de ratos Wistar com envelhecimento / Isabela Ugo Luques. -- São Paulo, 2009.

Orientador: li-Sei Watanabe.

Dissertação (Mestrado) - Universidade de São Paulo. Instituto de Ciências Biomédicas. Departamento de Anatomia. Área de concentração: Ciências Morfofuncionais. Linha de pesquisa: Ultra estrutura das células musculares.

Versão do título para o inglês: Structure and ultrastructure of the medial pterygoid muscle myotendinous junction in aging rats.

Descritores: 1. Músculo pterigóideo medial 2. Envelhecimento 3. Microscopia eletrônica de transmissão 4. Microscopia eletrônica de varredura I. Watanabe, li-Sei II. Universidade de São Paulo. Instituto de Ciências Biomédicas. Programa de Pós-Graduação em Ciências Morfofuncionais. III. Título.

ICB/SBIB230/2008 
Candidato(a):

Título da Dissertação:

Orientador(a):
Isabela Ugo Luques.

Estrutura e ultraestrutura da junção miotendínea do músculo pterigóideo medial de ratos wistar com envelhecimento .

A Comissão Julgadora dos trabalhos de Defesa da Dissertação de Mestrado, em sessão pública realizada a ./...................................,
( ) Aprovado(a)
( ) Reprovado(a)

Examinador(a): Assinatura:

Nome:

Instituição:

Examinador(a): Assinatura:

Nome:

Instituição:

Presidente: Assinatura:

Nome:

Instituição: 


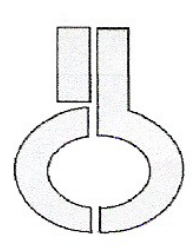

UNIVERSIDADE DE SĀO PAULO

INSTITUTO DE CIÊNCIAS BIOMÉDICAS

Cidade Universitária "Armando de Salles Oliveira"

Av. Prof. Lineu Prestes, 2415 - CEP. 05508-000 São Paulo, SP - Brasil

Telefone :(55) (011) 3091.7733 - telefax : (55) (011) 3091.7438

e-mail: cep@icb.usp.br

\section{CERTificado}

Certificamos que o protocolo registrado sob $\mathrm{n}^{\circ} 119$ nas fls. 40 do livro 2 para uso de animais em experimentação, sob a responsabilidade de Ii-Sei Watanabe, Coordenador(a) da Linha de pesquisa "Estrutura da junção miotendinea e do músculo pterigóideo medial na área de inserção na tuberosidade da tíbia da mandibula em ratos wistar com envelhecimento: Estudo aos microscópios al luz e eletrônico" do qual participou(aram) o(s) alunos Isabela Ugo Luques, está de acordo com os Princípios Éticos de Experimentação Animal adotado pelo Colégio Brasileiro de Experimentação Animal (COBEA) e foi aprovado pela COMISSÃO DE ÉTICA EM EXPERIMENTAÇÃO ANIMAL (CEEA) em 01.12.2006.

São Paulo, 01 de dezembro de 2006.

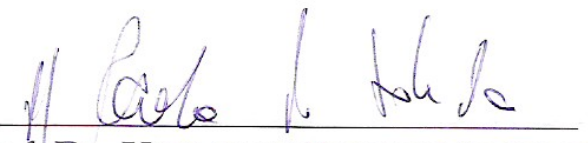

Prof. Dr. UBIRATAN FABRES MACHADO Coordenador da CEEA - ICB/USP

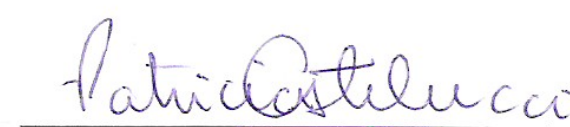

Profa. Dra. PATRÍCIA CASTELUCCI Secretária da CEEA - ICB/USP 
Aos meus pais, Luiz Carlos e Solange, e a minha irmã Mariana, pelo carinho e incentivo e por estarem sempre ao meu lado, acompanhando-me até aqui.

Vocês são muito importantes em tudo o que faço e meu amor por vocês é imenso!

Aos meus avôs Nélia, Giuseppe, Pedra e José e a minha bisavó Lina (in memorian) sempre preocupados e interessados, cujo apoio e carinho sempre foram fundamentais. 


\section{AGRADECIMENTOS}

Ao Prof. Dr. li-sei Watanabe pela orientação e atenção dispensada a mim e pelos valiosos conhecimentos compartilhados.

Aos meus colegas do Programa de Pós-graduação em Ciências Morfofuncionais Josemberg da Silva Baptista, William Paganini Mayer, Ricardo Bragança de Vasconcellos Fontes e Valquíria Barbozza Mariotti, por terem se tornado amigos tão queridos, pelo apoio e pelas contribuições.

Ao Prof. Dr. Edson Aparecido Liberti e a Profa ${ }^{\text {Dr. }}{ }^{\text {a }}$ Silvia de Campos Boldrini por terem me acolhido em seu laboratório, pelas brilhantes disciplinas ministradas, pelo exemplo profissional e por incitarem em mim a vontade de continuamente aprender anatomia humana.

As Sras. Marta Maria da Silva Righetti, Sonia Yokomizo e ao Sr. Sebastião Aparecido Boleta técnicos do Departamento de Anatomia do Instituto de Ciências Biomédicas pelos ensinamentos e colaboração nos trabalhos dentro do laboratório.

Ao meu namorado, Fernando Weber Scarano, pela paciência, pelo carinho e compreensão. 
Aos profissionais do Instituto Vita, em especial ao Dr. Wagner Castropil, ao Dr. Breno Schor, ao Dr. Alexandre Carneiro Bitar e ao Dr. Caio Oliveira D’Elia pelo apoio, pelo incentivo à pesquisa e por entenderem minhas ausências nos últimos dois anos.

E a todos aqueles que direta ou indiretamente contribuíram para minha pesquisa e meu crescimento durante estes anos de trabalho. 
"Aprender é a única coisa de que a mente nunca se cansa, nunca tem medo e nunca se arrepende." 


\section{LISTA DE FIGURAS}

\section{Rato com Envelhecimento}

Figura 1. Microscopia de luz mostrando a camada muscular aderente à superfície medial do ramo da mandíbula através de fibras de tecido conjuntivo.

Figura 2. Microscopia de luz revelando o tecido conjuntivo entre as fibras musculares formando feixes. 36

Figura 3. Microscopia de luz, evidenciando a presença de núcleos na porção periférica do sarcoplasma..... 36

Figura 4. Microscopia de luz aponta a junção da camada muscular e a superfície medial do ramo da mandíbula através de fibras de tecido conjuntivo e a presença de numerosos fibroblastos e vasos sangüíneos. 37

Figura 5. Revela o tecido conjuntivo que reveste as fibras musculares do pterigóideo medial e do masseter. 38

Figura 6. Mostra o tecido conjuntivo aderente ao tecido ósseo, revelando as inserções de fibras musculares e capilares. 38

Figura 7. Microscopia de luz das fibras musculares, vasos sanguíneos e tecido conjuntivo. 39

Figura. 8. O tecido conjuntivo do tecido ósseo é identificado em coloração avermelhada.

Figura 9. Nota-se o tecido conjuntivo corado em vermelho revelando a presença de endomísio de cada fibra muscular. 40

Figura 10. Corte examinado sob luz polarizada exibindo os aspectos esverdeado e avermelhado caracterizando a presença de fibras colágenas 41

Figura 11. Fotomicrografia de luz polarizada ressaltando as fibras musculares e o tecido conjuntivo do endomísio.

Figura 12. Fotomicrografia de luz polarizada mostrando as lamelas do corpo da mandíbula evidenciando o tecido conjuntivo na área de inserção, indicando a presença de fibras colágenas.

Figura 13. Microscopia eletrônica de varredura evidenciando a área de inserção do músculo pterigóideo medial na face interna do ângulo da mandíbula. 
Figura 14. Microscopia eletrônica de varredura quando se observa a inserção das

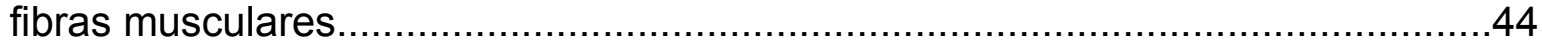

Figura 15. Microscopia eletrônica de varredura. Os forames nutrícios são evidenciados na superfície óssea. 45

Figura 16. Microscopia eletrônica de varredura. Observação de um forame nutrício. .45

Figura 17. Microscopia eletrônica de varredura. A peça tratada com solução de $\mathrm{NaOH}$ mostra nitidamente os feixes de fibras colágenas presentes no tecido ósseo mandibular. 46

Figura 18. Microscopia eletrônica de varredura registrando as fibras musculares dispostas longitudinalmente e o tecido colágeno presente entre as fibras 46

Figura 19. Microscopia eletrônica de varredura. Notam-se as redes de fibras colágenas entremeando as fibras do músculo pterigóideo medial dispostas longitudinalmente. 47

Figura 20. Microscopia eletrônica de varredura. Mostra a fibra muscular em corte longitudinal evidenciando as estriações características dos músculos esqueléticos. 47

Figura 21. Microscopia eletrônica de varredura. Músculo pterigóideo medial de rato com envelhecimento tratado com solução de $\mathrm{NaOH}$, evidencia o endomísio que envolve cada fibra muscular composto por tecido colágeno .48

Figura 22. Microscopia eletrônica de varredura. Amostra tratada com solução de $\mathrm{NaOH}$, revela a disposição do endomísio e rede de fibras colágenas 49

Figura 23. Microscopia eletrônica de transmissão mostrando o aspecto geral da camada muscular. .50

Figura 24. Microscopia eletrônica de transmissão, mostrando o citoplasma da célula muscular, revelando o núcleo na porção periférica e feixes de miofibrilas entremeadas de mitocôndrias. .51

Figura 25. Microscopia eletrônica de transmissão ressaltando o grupamento de mitocôndrias na porção periférica do sarcoplasma. 52

Figura 26. Microscopia eletrônica de transmissão. Mostra a concentração de mitocôndrias próximas à lâmina basal, na periferia da célula .52

Figura 27. Microscopia eletrônica de transmissão revelando as mitocôndrias e suas cristas compostas por dupla membrana além dos feixes de miofibrilas. 53 
Figura 28. Microscopia eletrônica de transmissão apontando o núcleo na porção periférica, feixes de fibras colágenas, as miofibrilas entremeadas de mitocôndrias e a disposição de tríades próximas à linha $Z$ e banda $I$.

Figura 29. Microscopia eletrônica de transmissão atentando à presença dos feixes de miofibrilas do músculo pterigóideo medial.................................................54

Figura 30. Microscopia eletrônica de transmissão exibindo mitocôndrias entremeando os feixes de miofibrilas. .55

Figura 31. Microscopia eletrônica de transmissão revelando o núcleo na porção periférica do citoplasma e os sarcômeros, evidenciando as bandas I, Z e A..........56

Figura 32. Microscopia eletrônica de transmissão mostrando mitocôndrias de forma circular e ovaladas, tríades e a disposição dos sarcômeros.........................56

Figura 33. Evidenciam-se mitocôndrias, tríades e sarcômeros...............................57

Figura 34. Microscopia eletrônica de transmissão. Observam-se nitidamente as mitocôndrias, com suas cristas mitocondriais e feixes de miofibrilas dispostas longitudinalmente. .58

Figura 35. Microscopia eletrônica de transmissão evidenciando as células endoteliais, revelando as projeções citoplasmáticas, cavéolas e junções entre as células. 59

Figura 36. Microscopia eletrônica de transmissão. llustrando um capilar e a presença de cavéolas e vesículas. .59

Figura 37. Microscopia eletrônica de transmissão mostrando as junções entre as células endoteliais do capilar sangüíneo e as projeções citoplasmáticas. 60

Figura 38. Microscopia eletrônica de transmissão. Observa-se a região da junção miotendínea do músculo pterigóideo medial.

Figura 39. Microscopia eletrônica de transmissão. Notam-se as invaginações dos feixes de miofibrilas e o tecido colágeno na região da junção miotendínea...... 61

Figura 40. Microscopia eletrônica de transmissão expondo as interdigitações dos feixes de miofibrilas e a presença de fibras colágenas que se ligam à membrana sarcoplasmática na região da junção.

Figura 41. Microscopia eletrônica de transmissão evidenciando as projeções em forma de dedos da junção miotendínea e a presença de miofibrilas.

Figura 42. Microscopia eletrônica de transmissão. Observam-se os feixes longitudinais de miofibrilas que compõem o endomísio..........................................63 


\section{Rato Adulto}

Figura 43. Microscopia de luz mostrando a área de inserção das fibras musculares na face medial do ângulo da mandíbula em corte longitudinal.

Figura 44. Microscopia de luz revelando a inserção oblíqua das fibras na mandíbula e a disposição dos núcleos das células musculares.

Figura 45. Microscopia de luz apontando as fibras musculares aderindo-se à superfície óssea através do tecido conjuntivo

Figura 46. Microscopia de luz revelando os forames nutrícios da superfície óssea. 65

Figura 47. Corte ilustrando a inserção das fibras musculares na superfície óssea. 66

Figura 48. Microscopia de luz revelando a presença de capilares na região da inserção muscular 66

Figura 49. Microscopia de luz evidenciando as fibras musculares entremeadas por feixes de fibras colágenas.

Figura 50. Na microscopia de luz nota-se a presença do tecido colágeno no osso mandibular.

Figura 51. Microscopia de luz onde se observa a presença do endomísio, envolvendo as fibras musculares. 68

Figura 52. Corte examinado sob luz polarizada revelando o tecido colágeno.......69

Figura 53. Fotomicrografia de luz polarizada mostrando as lamelas do corpo da mandíbula e evidenciando o tecido conjuntivo. 69

Figura 54. Corte examinado sob luz polarizada evidenciando a presença das fibras colágenas. 70

Figura 55. Microscopia eletrônica de varredura do ângulo da mandíbula e da área de inserção das fibras musculares

Figura 56. Microscopia eletrônica de varredura ilustrando as fibras longitudinais do músculo inserindo-se na mandíbula.

Figura 57. Microscopia eletrônica de varredura. Observam-se as fibras musculares dispostas longitudinalmente. .71 
Figura 58. Microscopia eletrônica de varredura evidencia os feixes de fibras em corte transversal.

Figura 59. Microscopia eletrônica de varredura evidenciando os forames nutrícios. .72

Figura 60. Microscopia eletrônica de varredura demonstrando a área de inserção das fibras musculares do pterigóideo medial. .73

Figura 61. Microscopia eletrônica de varredura evidencia a inserção da fibra muscular no tecido ósseo. 73

Figura 62. Microscopia eletrônica de varredura de corte transversal das fibras musculares.

Figura 63. Microscopia eletrônica de varredura confirmando a presença de estriações que caracterizam os músculos esqueléticos. .74

Figura 64. Microscopia eletrônica de varredura evidenciando as estriações da fibra muscular. .75

Figura 65. Microscopia eletrônica de varredura revelando o endomísio. .76

Figura 66. Amostra tratada com solução de $\mathrm{NaOH}$, mostrando o endomísio e revelando a disposição do tecido colágeno. 76

Figura 67. Microscopia eletrônica de varredura evidenciando as redes de tecido colágeno. .77

Figura 68. Microscopia eletrônica de transmissão trazendo o aspecto geral da fibra muscular e os sarcômeros. 78

Figura 69. Microscopia eletrônica de transmissão, mostrando os sarcômeros entremeados por mitocôndrias. .78

Figura 70. Microscopia eletrônica de transmissão, atentando-se às mitocôndrias entremeando-se às miofibrilas. 79

Figura 71. Microscopia eletrônica de transmissão demonstrando os feixes de miofibrilas 80

Figura 72. Microscopia eletrônica de transmissão exibindo núcleo da célula muscular localizado na sua porção periférica.

Figura 73. Microscopia eletrônica de transmissão revelando as mitocôndrias e suas cristas com dupla membrana. 
Figura 74. Microscopia eletrônica de transmissão aponta a junção miotendínea..82

Figura 75. Microscopia eletrônica de transmissão revela as interdigitações da junção miotendínea em forma de dedos 83

Figura 76. Microscopia eletrônica de transmissão revelando os feixes de miofibrilas interdigitando-se com as projeções de diferentes tamanhos .83

Figura 77. Microscopia eletrônica de transmissão onde se visualizam as fibras tendíneas invaginando-se entre os feixes de miofibrilas 84

Figura 78. Microscopia eletrônica de transmissão expondo as invaginações das miofibrilas. 84 


\section{RESUMO}

LUQUES I. U. Estrutura e ultraestrutura da junção miotendínea do músculo pterigóideo medial de ratos wistar com envelhecimento. 2008. $96 \mathrm{f}$. Dissertação (Mestrado em Ciências Morfofuncionais) - Instituto de Ciências Biomédicas, Universidade de São Paulo, São Paulo, 2008.

As características das células musculares e da junção miotendínea do músculo pterigóideo medial de ratos adultos e com envelhecimento foram estudadas, empregando-se as técnicas de microscopia de luz e eletrônica de varredura e de transmissão. A microscopia de luz mostrou que as fibras musculares inserem-se na superfície óssea mandibular através de tecido colágeno composto por numerosos fibroblastos. Os cortes examinados sob luz polarizada revelaram a presença de fibras colágenas tipo I e III nesta região. Além disso, puderam-se notar os capilares sangüíneos em grande número. Observações ao microscópio eletrônico de varredura ressaltaram as estriações presentes no músculo esquelético. $O$ tecido conjuntivo que constitui o endomísio foi notado quando as amostras foram tratadas com solução de hidróxido de sódio e foi possível observar os diferentes diâmetros apresentados pelas fibras musculares. A microscopia eletrônica de transmissão evidenciou o alinhamento dos sarcômeros e as concentrações de mitocôndrias junto à lâmina basal na terminação da fibra muscular. O estudo da junção miotendínea dos ratos adultos e com envelhecimento identificou as fibras colágenas e os feixes de miofibrilas formando interdigitações que promovem o aumento da superfície de contato nesta região. Os aspectos observados nos músculos de ratos adultos mostraram-se bastante similares aos encontrados nos ratos com envelhecimento.

Palavras-chave: Músculo pterigóideo medial; Microscopia eletrônica de varredura; Microscopia eletrônica de transmissão; Envelhecimento. 


\section{ABSTRACT}

LUQUES I. U. Structure and ultrastructure of the medial pterygoid muscle myotendinous junction in Wistar rats with aging. 2008. $96 \mathrm{f}$. Master thesis (Master in Morphofunctional Sciences) - Instituto de Ciências Biomédicas, Universidade de São Paulo, São Paulo, 2008.

The medial pterygoid muscle cells and myotendinous junction characteristics of adult and aging rats were studied, using light microscopy and scanning and transmission electron microscopy techniques. The light microscopy showed the muscle fibers inserting in the mandible surface through collagen tissue and numerous fibroblasts. The samples examined in polarized light revealed the presence of type I and III collagen fibers in this site. Furthermore, the numerous blood capillaries could be noticed. Observations at the scanning electron microscope evidenced strias present in the skeletal muscle. The connective tissue that constitutes the endomysium could be noticed when the samples were treated with sodium hydroxide solution and it was possible to observe the muscle fibers different diameters. The transmission electron microscopy revealed the sarcomeres alignment and the mitochondria concentration by the basal lamina in the muscle fiber termination. The adult and aging rats myotendinous junction study showed the collagen fibers and the myofibrils bundles developing finger-like processes that increases the contact areas in this site. The aspects seen in adult rats pterygoid muscles were very similar to the ones seen in the aging rats.

Key words: Medial pterygoid muscle; Scanning electron microscopy; Transmission electron microscopy; Aging. 


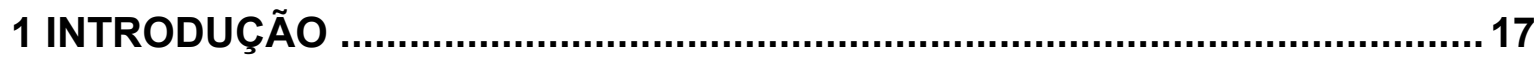

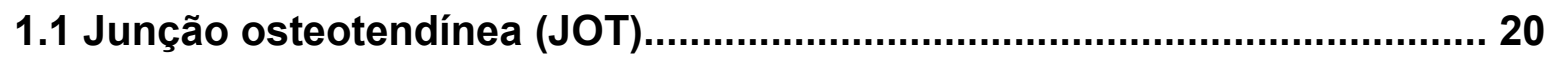

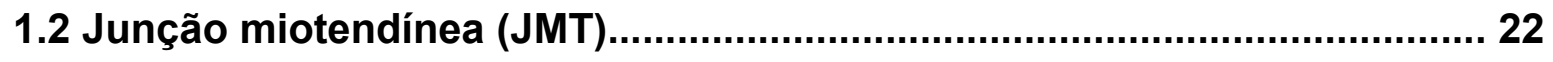

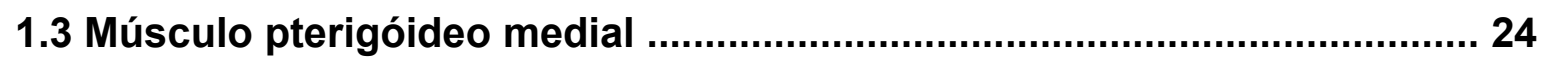

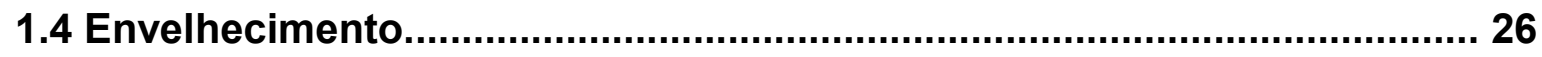

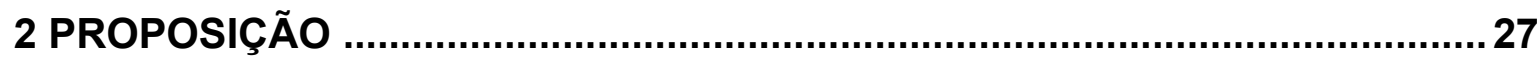

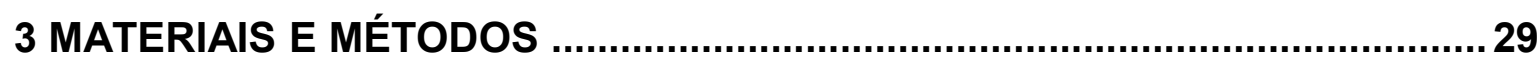

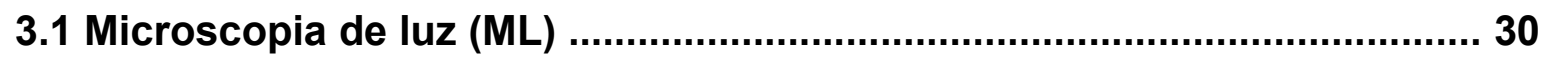

3.2 Microscopia eletrônica de varredura (MEV) ............................................ 31

3.3 Microscopia eletrônica de transmissão (MET) …..................................... 32

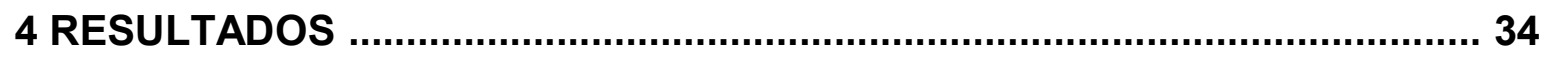

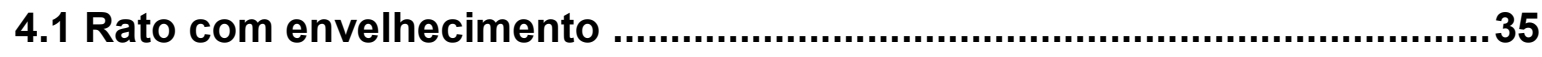

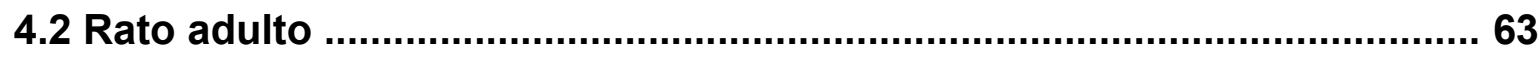

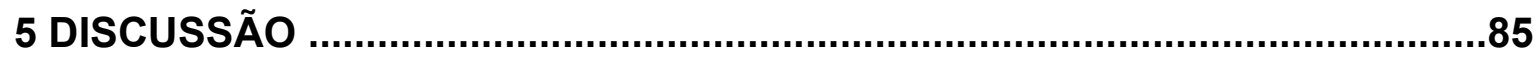

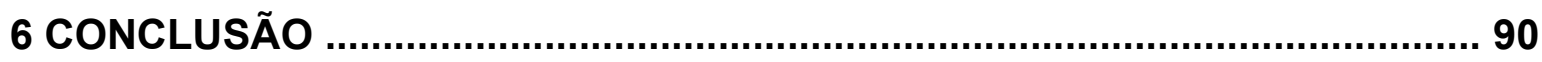

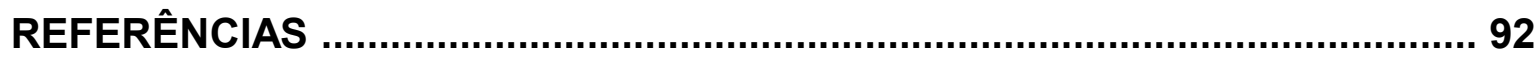


1 INTRODUÇÃO 
Sabe-se que no embrião, o mesoderma diferencia-se em osso, cartilagem, músculo, ligamento/tendão, tecido conjuntivo e outras estruturas segundo Caplan (1994).

O tecido conjuntivo é composto de variadas células produtoras de fibras e substância fundamental amorfa (JUNQUEIRA e CARNEIRO, 1995). As principais fibras produzidas são as colágenas, reticulares e elásticas. No estado fresco, as fibras colágenas, as mais abundantes no tecido conjuntivo, são brancas, tornando, assim, brancos e brilhantes os tendões saudáveis.

Os tendões são estruturas interpostas entre 0 músculo e o osso responsáveis pela transmissão de forças geradas no músculo (MADEIRA, 1971). Dependendo da ação do músculo e da força desenvolvida o tendão terá características distintas em relação à forma, largura e comprimento.

Os tendões não podem ser distinguidos um do outro ao nível do microscópio eletrônico (DYER E ENNA, 1976), pois são formados por feixes paralelos de fibras colágenas entremeados por pequena quantidade de substância amorfa e fibroblastos diferenciados (com núcleos alongados e prolongamentos) (JUNQUEIRA e CARNEIRO, 1995). Há diferenças de diâmetros destas fibrilas de acordo com a idade e órgão considerado, podendo variar entre $10 \mathrm{~nm}$ e $400 \mathrm{~nm}$ segundo Dyer e Enna (1976).

No homem, tendões como os dos músculos plantar e palmar possuem propriedades físicas diferentes de outros tendões, permitindo maior alongamento lateral, enquanto outros se romperiam sob as mesmas condições. Isso provém do fato de as fibras colágenas destes tendões não se apresentarem rodadas ao estenderem o comprimento do tendão, segundo Dyer e Enna (1976).

As fibras colágenas dos tendões descritas por Junqueira e Carneiro (1995) aparecem agrupadas paralelamente formando feixes e estas fibras por sua vez, são constituídas por fibrilas. As fibras colágenas constituem uma família de proteínas que se distinguem por algumas variáveis, tendo mais de doze tipos e sendo mais freqüentes as formadas por colágeno do tipo I e tipo III. 
Além disso, o tendão é composto de células que na sua maioria, 90 a 95\%, são tenócitos e tenoblastos. As outras células são os condrócitos, células sinoviais e células vasculares.

Os tenócitos estudados por microscopia eletrônica por Józsa et al. (1979), aparecem como células ativas com retículo endoplasmático rugoso e complexo de Golgi muito desenvolvidos e grandes quantidades de ribossomos livres no citoplasma. Apresentam poucas mitocôndrias, porém com cristas bem definidas, vacúolos lipídicos e lisossomos em número variado e alguns pseudópodes ocasionalmente projetados, evidenciando atividade fagocitária.

Em seu estudo ultraestrutural, também utilizando material humano, Dyer e Enna (1976) observaram tenócitos, caracterizados como células atenuadas, com organelas citoplasmáticas mínimas e também numerosos tenoblastos (tenócitos jovens), contendo retículo endoplasmático rugoso e complexo de Golgi muito desenvolvidos além de vesículas micropinocíticas evidentes na membrana celular. Estas células, estando associadas a altas atividades metabólicas e de secreção, mais uma vez demonstram haver atividade metabólica na região do tendão.

Com o envelhecimento, os tenoblastos se transformam em tenócitos e tornam-se estruturas alongadas com processos celulares delgados e longos, sendo necessários para manutenção do contato íntimo entre as células. Os componentes da matriz compensam, assim, o decréscimo do número de células e aumento na quantidade de matriz do tendão pelo envelhecimento segundo Kannus (2000).

Considerando-se os envoltórios tendíneos, histologicamente, de acordo com Kannus (2000) os tendões são recobertos por um tecido conjuntivo frouxo chamado paratendão, encontrando-se em áreas onde não há revestimentos sinoviais verdadeiros. O revestimento sinovial, mais freqüentemente encontrado nos tendões dos músculos dos membros, evidencia duas camadas, uma parietal e outra visceral que formam um ducto contendo um líquido peritendíneo.

O paratendão também é responsável por evitar a fricção do tendão com outras superfícies além de permitir livre movimentação tendínea frente às outras 
estruturas adjacentes. O paratendão é constituído de fibrilas colágenas do tipo I e do tipo III (KANNUS, 2000).

Ainda, abaixo do paratendão, todo o tendão está envolto for uma camada fina de tecido conjuntivo, o epitendão. Em sua superfície externa, o epitendão é contíguo ao paratendão e em sua superfície interna ao endotendão. Internamente ao tendão, o endotendão envolve cada fibra tendínea e liga fibras individuais.

O epitendão, uma rede de fibrilas de colágeno longitudinais, oblíquas e transversas relativamente densa (8 a $10 \mathrm{~nm}$ de espessura). Ocasionalmente, estas fibrilas estão fundidas àquelas do tendão localizadas mais superficialmente. O endotendão é uma fina rede reticular de tecido conjuntivo interna ao tendão que envolve as fibras do tendão e as interligam.

No estudo de Kannus (2000), demonstrou-se que, para aumentar a ligação entre as fibrilas e fibras, há um alto grau de hidralação de componentes proteoglicanas entre o endotendão e a superfície dos fascículos do tendão. Juntamente as suas importantes funções de ligação, a rede do endotendão permite que os grupos de fibras deslizem uns sobre os outros e carreguem vasos sangüíneos, nervos e linfáticos à porção mais tendínea profunda.

\subsection{Junção osteotendínea (JOT)}

Partindo-se para a observação da junção osteotendínea (JOT), a área entre o osso e o tendão no músculo quadríceps de ratos, foi comparada por Järvinen et al. (1999) às superfícies articulares. Alguns estudos mostram que na região de inserção tendínea na epífise óssea há quatro zonas que promovem uma transição gradual do tecido mole para o ósseo. Estas zonas são divididas em: tendão, fibrocartilagem, fibrocartilagem calcificada e osso (COOPER, 1970; BENJAMIN et al., 1986, 1992).

Raspanti et al. (1996) demonstraram que o ligamento patelar, caracterizado por uma estrutura similar a de um tendão, se dilata ao aproximar-se de seu ponto 
de inserção tibial, separando-se em fascículos colágenos pela interposição de fileiras de células e matriz extracelular rica em proteoglicanas. Os autores frisam que estas células que aparecem como tenócitos, tornam-se cilíndricas próximas à inserção e arredondadas banhadas por uma matriz extracelular. Este conjunto forma um tecido similar à cartilagem que vai se misturar aos fascículos tendíneos continuando-se além da face de mineralização.

Utilizando o tendão do músculo quadríceps, Clark et al. (1998) evidenciaram que as fibras do tendão se interdigitam ao sistema lamelar ósseo, mas não se fundem ao sistema colágeno das lamelas individuais.

Järvinen et al. (1999) também observaram em seu estudo com ratos que as células se dispõem em pares ou fileiras cercadas por um espaço lacunar da matriz extracelular (MEC). Na transição do tendão para a JOT, as células se tornam largas e arredondadas e observou-se claramente a estrutura típica de leque da JOT, formada pela dispersão das fibras colágenas (transmitindo forças do tendão viscoelástico para o osso) assim como a margem distinta, nomeada de "cimentada" ou "linha azul" (devido à intensa afinidade da linha quando corada com hematoxilina-eosina), entre as zonas de fibrocartilagem e fibrocartilagem calcificada da junção. Os feixes colágenos eram uniformes em largura, mas o fenômeno das pregas, característicos de fibras colágenas de tecidos tendíneos examinados ao microscópio polarizado, foi visto apenas na junção e não em outra parte do tendão.

Em análise planimétrica de Järvinen et al. (1999), a fibrocartilagem e a fibrocartilagem calcificada eram quase iguais em diâmetro, enquanto a zona óssea da JOT era duas vezes mais grossa que estas duas outras zonas. Além disso, pesquisas histológicas de Benjamin et al. $(1986,1992)$ indicam que os tendões geralmente se conectam ao osso pela interposição de uma placa de fibrocartilagem, assim implicando que a força tensora passa para a fibrocartilagem através do tendão e desta para o osso. 
Estudos imunohistoquímicos demonstraram a presença de colágeno tipo II ao nível da JOT do ligamento patelar de ratos e presença quase exclusiva de colágeno tipo I no tendão e no osso, segundo Raspanti et al. (1996).

O local onde um tendão se conecta ao osso é denominado pelos reumatologistas de entese, de acordo com Morriggl et al. (2003), estando recoberta por fibrocartilagem. Rufai et al. (1996) verificaram que o local de inserção do tendão calcâneo é composto por três fibrocartilagens: fibrocartilagem entesial (na JOT), fibrocartilagem sesamóide (na superfície profunda do tendão próxima ao calcâneo) e fibrocartilagem periosteal (recobrindo a face oposta do osso).

\subsection{Junção miotendínea (JMT)}

A junção miotendínea (JMT) é o local de transmissão da força de contração das fibras musculares para tendão. Ultraestruturalmente, Nakao (1975) observou que as fibras do tendão emitem processos que se interdigitam às fibras musculares aumentando assim a área de contato entre estas estruturas.

Järvinen et al. (1991) investigaram sua composição macromolecular do tendão calcâneo de ratos, encontrando como principal componente as fibras de colágeno tipo I, pequenas quantidades de colágeno tipo III e presença de fibronectina nas superfícies das fibras musculares na junção. Os autores também observaram ser uma região rica em polissacarídeos aumentando a força adesiva entre a membrana da célula muscular e as fibrilas colágenas tendíneas o que melhoraria a capacidade elástica da junção frente à carga.

De acordo com Viidik (1973), muitos autores consideram que nas JMT os feixes tendíneos estão invaginados ao final das fibras musculares nas muitas interdigitações do sarcolema. Este arranjo criaria uma superfície de contato considerável entre a fibra muscular e as fibrilas colágenas, promovendo maior estabilidade mecânica. Porém este conceito vem sendo desafiado considerando- 
se, então, que as fibrilas colágenas, ligadas às membranas plasmáticas assim como às fibras colágenas, promovam a junção.

A junção miotendínea do diafragma, quando estudada em coelhos por Souza et al. (1988), apresentou sarcolema com fendas e invaginações, cada uma recoberta pela lâmina basal, aonde vão se ligar obliquamente às fibras colágenas, aqui, sinuosas como nas vilosidades intestinais. Estas fendas e invaginações da JMT aumentam a superfície de conexão das fibrilas do tendão e com isso reduzem a força de cisalhamento por unidade de área. Estas pregas das fibras colágenas também foram estudadas por Kastelic et al. (1978) que notaram que suas angulações decrescem significativamente ao centro do fascículo.

Eisenberg e Milton (1984), ao estudarem a terminação da fibra muscular do músculo sartório do sapo, observaram a aparência ultraestrutural altamente interdigitada, implicando na melhora do contato mecânico que aumenta a área pela qual a força será transmitida ao tendão.

Estas pregas, ou dobras da membrana, aumentam a área da superfície juncional 13,2 vezes de acordo com Tidball (1984).

Além disso, no estudo de Eisenberg e Milton (1984) evidenciou-se um aumento no conteúdo mitocondrial, implicando em alta taxa de fosforilação oxidativa na região, porém ainda não se sabe se o ATP extra é utilizado para a manutenção da JMT, criação de novos sarcômeros ou outras atividades. Os autores descreveram o decréscimo de retículo sarcoplasmático longitudinal como conseqüência do permanente comprimento reduzido do sarcômero na junção miotendínea.

Trotter et al. (1983) realizaram um estudo da junção miotendínea dos músculos diafragma, plantar e extensor radial longo do carpo de ratos para análise da lâmina interna, importante na transmissão de forças dos miofilamentos para as fibras tendíneas.Os autores afirmaram que os filamentos de actina do último sarcômero se estendem da miofibrila à membrana plasmática, participando da JMT. Além das invaginações da fibra muscular diminuírem o estresse, as fibras 
colágenas e a lâmina interna são paralelas entre si estando sujeitas às forças de cisalhamento, e não forças de tensão, quando o músculo se contrai.

Considerando-se a vascularização e a microvascularização, a primeira, referente ao tendão patelar, é feita por três diferentes vias: as que dão entrada nos locais de inserção do tendão, as que entram na junção musculotendínea e as de substância intermédia adjacentes aos tecidos moles. Afirma-se que, mais proximalmente, a metade inferior do tendão patelar e a camada adiposa de Hoffa, tecido adiposo presente ao redor deste tendão, são muito vascularizadas. No entanto, as junções osteotendíneas são relativamente avasculares, principalmente na inserção junto à tuberosidade anterior da tíbia e na origem ao nível do pólo inferior da patela, como relataram Khan et al. (1998).

Warren et al. (1988) realizaram um estudo sobre a microvascularização da inserção distal do tendão extensor dos dedos das mãos de seis cadáveres humanos, constatando a presença de uma área avascular próxima à junção osteotendínea.

A fibrocartilagem calcificada das inserções tendíneas e capsulares dos colos femurais de ovelhas envelhecidas foi determinada avascular por Shea et al. (2002), e nas regiões do fêmur proximal que possuíam inserções, o periósteo era avascular.

\subsection{Músculo pterigóideo medial}

O músculo pterigóideo medial compõe os músculos da mastigação, incluindo o músculo masseter, o músculo temporal e o músculo pterigóideo lateral. Situa-se na parte interna da mandíbula, conforme foi relatado por Smith et al. (1997). O músculo tem a origem na fossa pterigóide do osso esfenóide, como inserção, o lado medial do ramo e ângulo da mandíbula, muitas vezes interdigitando-se com fibras do músculo masseter, e sua inervação provém do nervo pterigóideo medial, ramo do nervo mandibular do nervo trigêmeo. 
Além do grande componente de força de elevação da mandíbula, o $\mathrm{m}$. pterigóideo medial possui um componente de força medial para equilibrar o componente lateral do masseter (SMITH et al., 1997).

El Haddioui et al. (2007) estudaram o ciclo mastigatório e associaram a grande força gerada pelo músculo pterigóideo medial ao seu sistema aponeurótico intramuscular que aparece composto por camadas tendíneas longas e fortes.

Kawagoe et al. (1997) relataram em seu estudo de análise histoquímica, que o músculo pterigóide medial, insere-se à margem inferior do ramo próximo ao ângulo da mandíbula, apresentando neste local fortes colorações de fibras colágenas do tipo I, III e V.

Herms e Tillman (2000) descreveram as fibras curtas do tendão do músculo pterigóideo medial, unindo-se na camada superficial do periósteo. Já as fibras longas se espalham, formando um leque, antes de se entremearem ao periósteo e então se fixam diretamente no osso.

Segundo estes autores, a inserção na placa pterigóidea lateral é uniforme para ambas as superfícies medial e lateral sendo que as fibras musculares se inserem através de tendões curtos em um periósteo bastante delgado que consiste em fibrilas colágenas reticulares. $\mathrm{Na}$ zona de junção do músculo pterigóideo medial na superfície medial do ângulo da mandíbula, eles observaram três tipos diferentes de ênteses: tendões curtos se entrelaçando às fibras colágenas do periósteo; fibras do tendão longo se inserindo diretamente no osso; tendões longos formando, na tuberosidade, junções através do tecido fibrocartilaginoso (calcificado próximo ao osso). Uma linha separa a cartilagem calcificada, sobre a superfície do osso, da cartilagem não-calcificada, afastada do osso.

Van Eidjen et al. (1997) estudaram os músculos mastigatórios e descreveram o músculo pterigóideo medial como sendo músculo penado.

$\mathrm{O}$ ângulo de disposição das fibras é um dos fatores de mudanças na força e velocidade de contração, assim como os sarcômeros e seus arranjos, paralelos e em série. Além disso, o arranjo das fibras musculares também influencia a função e são essas características que buscamos observar neste estudo. 
A justificativa deste estudo prende-se ao fato de que presentemente não há dados sobre a ultraestrutura do músculo pterigóideo medial na fase de envelhecimento. Procura-se conhecer as características morfofuncionais para compreender mudanças na geração de força e potência deste músculo durante os mecanismos mastigatórios, comparando com as estruturas de animais adultos.

\subsection{Envelhecimento}

Após a quarta década de vida, os músculos têm uma perda de $8 \%$ de sua massa total a cada década seguinte e essa perda deve-se à redução do nível de atividade física, alterações no metabolismo de esteróides, função da hipófise, entre outros fatores segundo Cannon, 1998.

O músculo esquelético de um indivíduo de 70 anos apresenta redução da área seccional transversa em até $30 \%$ e a força reduzida em até $40 \%$ (PORTER et al., 1995). Segundo Lexell et al. (1988), as razões para tais reduções são a diminuição do número total de fibras musculares e a atrofia das fibras remanescentes.

Com o envelhecimento, nota-se que as fibras musculares são mais suscetíveis às lesões e há redução da capacidade de recuperação e adaptação muscular após exercícios periódicos (MCARDLE et al., 2001). O aumento da produção de radicais livres e sua ação no sistema muscular no envelhecimento ainda não estão definidos (MCARDLE et al., 2001).

A função dos músculos da mastigação é mais complexa do que a musculatura dos membros por ser influenciada pela informação sensorial e estímulos provenientes da gengiva e dos dentes (NORTON et al., 2001). Entretanto, em estudos utilizando ratos machos mostrou-se que as características musculares e a capacidade de gerar tensão do feixe anterior profundo do músculo masseter não diminuem com a idade (NORTON et al., 1995). Além disso, Norton et al. (2001) demonstraram que o músculo masseter de ratos são mais fadigáveis com o aumento da idade e a fadiga foi associada às alterações nos mecanismos de contração-relaxamento. 
2 PROPOSIÇÃO 
Em face dos dados obtidos na literatura, no presente trabalho pretendemos analisar os seguintes aspectos do músculo pterigóideo medial:

2.1 Aspectos histológicos das estruturas constituintes do músculo pterigóideo medial na área de inserção junto ao ângulo da mandíbula em ratos com envelhecimento e ratos adultos;

2.2 Características estruturais das fibras musculares, do tecido conjuntivo e da superfície óssea da mandíbula, empregando os métodos de microscopia eletrônica de varredura nos ratos com envelhecimento e ratos adultos;

2.3 Características ultra-estruturais das células musculares, empregando os métodos de microscopia eletrônica de transmissão nos ratos com envelhecimento e ratos adultos. 
3 MATERIAIS E MÉTODOS 
Neste estudo foram utilizados 20 ratos, machos e fêmeas, Wistar com envelhecimento (mais de dois anos), com peso aproximado de $250 \mathrm{~g}$. Os ratos adultos (de 12 a 14 meses), em mesmo número, foram examinados para a comparação das estruturas musculares. Para a obtenção das peças, após a anestesia dos animais com Hypnol $3 \%, 5 \mathrm{ml}$, os animais foram decapitados e os músculos pterigóideos mediais direito e esquerdo foram dissecados cuidadosamente, removendo-se juntamente com as partes ósseas da mandíbula contendo as áreas de inserção muscular.

\subsection{Microscopia de luz (ML)}

Após a remoção quatorze peças foram imediatamente imersas em solução fixadora de Bouin, contendo $75 \mathrm{ml}$ de solução aquosa saturada de ácido pícrico, $25 \mathrm{ml}$ de formalina (solução de formaldeído a 40\% formol puro) e $5 \mathrm{ml}$ de ácido acético glacial durante 48 horas à temperatura ambiente no Laboratório de Microscopia Eletrônica do Departamento de Anatomia do Instituto de Ciências Biomédicas da Universidade de São Paulo. Em seguida, as peças foram lavadas em água corrente e posteriormente imersas em solução descalcificadora (EDTA etilenodiaminotetracetato de tetrasódio, sal dissódico - a 10\%) por vários dias.

Para verificar a descalcificação, foram realizados testes a cada 48 horas com solução de oxalato de amônia $(5 \mathrm{ml})$ e hidróxido de amônia $(5 \mathrm{ml})$ até que a solução descalcificadora não se apresentasse mais turva durante o teste.

Para a desidratação das peças, foi utilizada a série crescente de álcoois a partir de $70 \%$ por 24 horas, 95\% por uma hora, 100\%-I por uma hora, álcool $100 \%$-II por duas horas e $100 \%$-III por uma hora.

Em seguida as peças foram tratadas com xilol I, II e III por três banhos consecutivos de 30 minutos em cada solução.

A embebição da peça pela parafina foi feita na estufa a fim de se retirar 0 xilol e substituir gradativamente desde a parafina I (20 minutos) seguida por 
parafina II (45 minutos) e parafina III (15 minutos) até, por último, chegar ao banho de parafina pura para a inclusão.

As peças foram incluídas em blocos de parafina de forma retangular a fim de se obter cortes transversais e longitudinais da área de inserção do músculo pterigóideo medial na mandíbula para que se evidenciem as áreas de inserção musculares e ósseas. Cortes de sete micrometros de espessura foram montados em lâminas de vidro e corados pelos métodos hematoxilina-eosina para examinar as características das fibras musculares, núcleos e tecido ósseo, Azo-Carmim para analisar a distribuição do tecido conjuntivo entre as fibras musculares e na área de inserção e Picrosirius. As lâminas coradas em Picrosirius foram examinadas com luz polarizada para a verificação dos feixes de fibras colágenas que constituem o endomísio e perimísio, segundo método descrito por Junqueira et al. (1979).

\subsection{Microscopia eletrônica de varredura (MEV)}

Para a microscopia eletrônica de varredura, sete animais foram anestesiados com Hypnol 3\% e fixados por perfusão através do ventrículo esquerdo do coração com a solução de Karnovsky modificada, contendo 2,5\% de glutaraldeído e $2 \%$ de paraformaldeído em solução tampão de fosfato de sódio 0,1 $\mathrm{M}(\mathrm{pH} 7,3)$ à $4{ }^{\circ} \mathrm{C}$ durante 24 horas.

Após a fixação, quatorze peças foram, então, fraturadas congelando-as em nitrogênio líquido, lavadas em solução tampão de fosfato de sódio por 15 minutos e pós-fixadas em solução tamponada de tetróxido de ósmio a $1 \%$ à $4{ }^{\circ} \mathrm{C}$ durante 2 horas. Posteriormente, foram lavadas em água destilada por três horas e imersas em solução de ácido tânico a 1\% por uma hora conforme o método de Murakami (1974).

Em seguida, os tecidos, foram desidratados em série crescente de etanol e realizou-se a secagem no aparelho de ponto crítico Balzers CPD - $030{ }^{(1)}$, utilizando-se $\mathrm{CO}_{2}$ líquido. 
As amostras foram montadas em base metálica usando o esmalte $\mathrm{e}$ cobertas com íons de ouro em aparelho IONS Balzers SCD - $040{ }^{\text {(2) para }}$ observação ao microscópio eletrônico de varredura Jeol, JSM $6.100^{(3)}$.

(1) Processo FAPESP.

(2) Processo FAPESP.

(3) Processo FAPESP, ICB - USP.

Para evidenciação do tecido colágeno, após a fixação em solução de Karnovsky modificado, procedeu-se a fratura em nitrogênio líqüido. As amostras foram imersas em $\mathrm{NAOH}$ a $10 \%$ por 3 a 6 dias em temperatura ambiente (OHTANI, 1987) e lavadas em água destilada por 24 horas até que as peças se tornassem transparentes. Posteriormente, foram pós-fixadas em solução de tetróxido de ósmio a $1 \%$ à $4{ }^{\circ} \mathrm{C}$ durante 2 horas, seguindo-se, então, a mesma seqüência utilizada para observação das fibras musculares.

\subsection{Microscopia eletrônica de transmissão (MET)}

Para a obtenção de material, seis animais foram anestesiados com Hypnol $3 \%$ e perfundidos com solução de Karnovsky modificada contendo $2,5 \%$ de glutaraldeído, $2 \%$ de paraformaldeído em solução tampão de fosfato de sódio a $0,1 \mathrm{M}(\mathrm{pH} 7,3)$ de acordo com a técnica relatada por Watanabe e Yamada (1983) e amostras com tamanhos de 1 a $3 \mathrm{~mm}^{3}$ foram fixadas na mesma solução .

Apos a fixação, doze peças foram pós-fixadas em solução de tetróxido de ósmio a $1 \%$ em solução tampão de fosfato de sódio durante 2 horas à $4{ }^{\circ} \mathrm{C}$. Em seguida, os tecidos foram desidratados em série crescente de álcoois a partir de $60 \%$ até o absoluto, embebição em solução de óxido de propileno e resina Spurr na proporção de 1:1 durante 8 horas a temperatura ambiente. Posteriormente, foram incluídos em resina pura durante 6 horas e em seguida, a inclusão em resina pura em moldes de borracha e levando-se a estufa a $60{ }^{\circ} \mathrm{C}$ durante 36 horas. Após a polimerização, foi feita a trimagem dos blocos e cortes espessos de 1-3 um em ultramicrótomo Reichert Ultra Cut utilizando a faca de vidro. Os cortes 
evidenciando as estruturas do ventre muscular do pterigóideo medial e da junção miotendínea foram corados em azul de toluidina para o exame ao microscópio de luz e localização de áreas de interesse.

Os cortes ultrafinos de $90 \mathrm{~nm}$ de espessura foram obtidos com a faca de diamante e coletados em telas de 200 "mesh". Em seguida, as telas foram contrastadas com a solução de acetato de uranila a 4\% (WATSON, 1958) e citrato de chumbo a 0,4\% (REYNOLDS, 1963) e examinadas em microscópio eletrônico de transmissão Jeol 1010 regulado para 60 kv do Instituto de Ciências Biomédicas da Universidade de São Paulo. 
4 RESULTADOS 


\section{Rato com envelhecimento}

Os cortes histológicos da área de transição entre o músculo pterigóideo medial e a mandíbula de ratos com envelhecimento fixados em solução de Bouin e corados com a solução de hematoxilina-eosina, Azo-Carmin e Picrosirius revelaram ao microscópio de luz, a camada muscular aderente à superfície medial do ramo da mandíbula contendo numerosos feixes de fibras de tecido conjuntivo. O tecido conjuntivo entre as fibras musculares é notado formando feixes orientados em várias direções (Fig. 1).

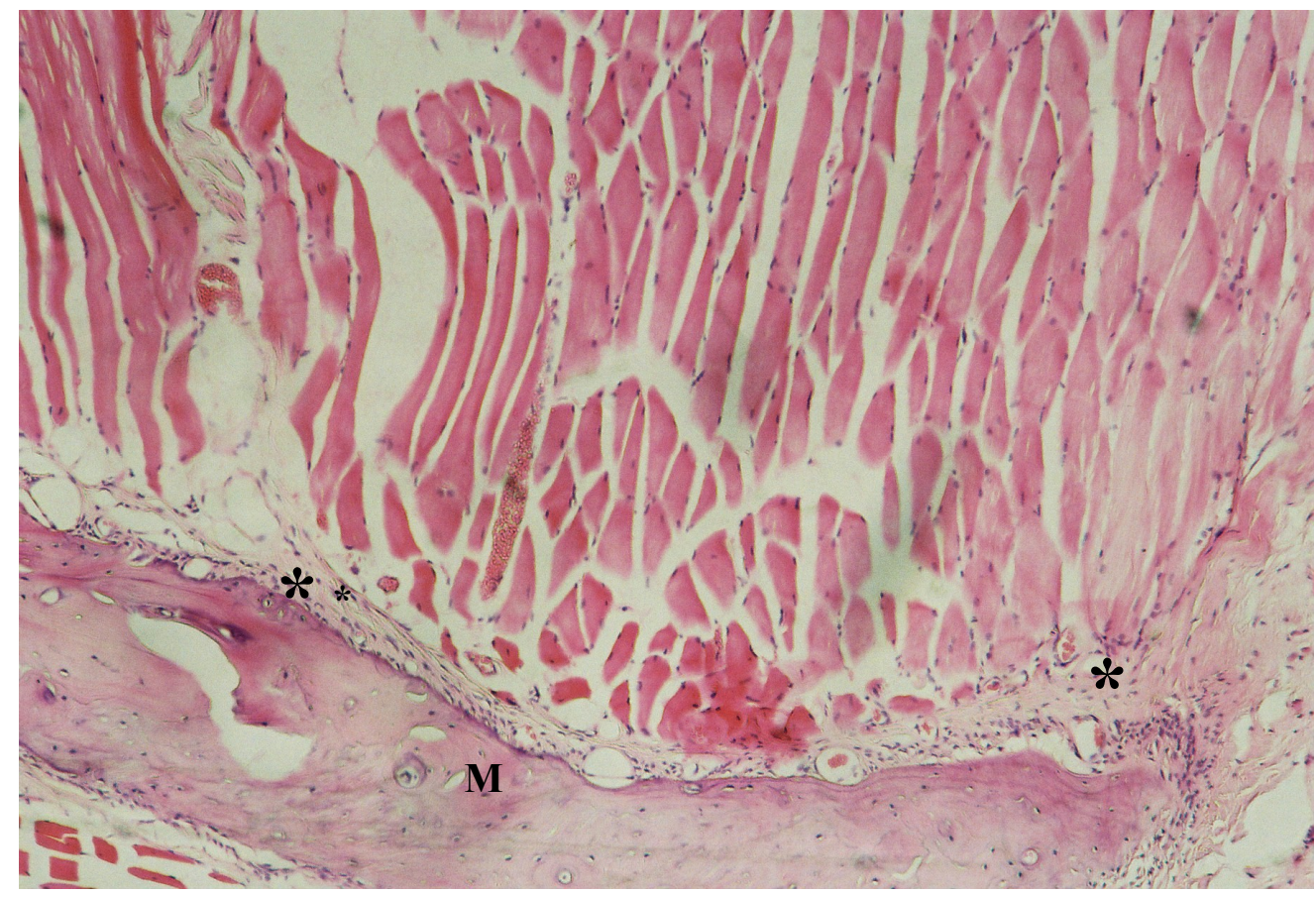

Figura 1. Microscopia de luz. Corte histológico transversal do músculo pterigóideo medial de rato com envelhecimento. Mostra a camada muscular aderente à superfície medial do ramo da mandíbula $(\mathrm{M})$ através de fibras de tecido conjuntivo $\left({ }^{*}\right)$. $64 \mathrm{X}$ Coloração: HematoxilinaEosina.

A camada muscular examinada ao microscópio de luz apresenta-se a disposição de fibras musculares longitudinalmente, com a disposição de núcleos na periferia do citoplasma (Fig.2). Observaram-se os núcleos de formas cilíndricas e alongadas (Fig. 3). 


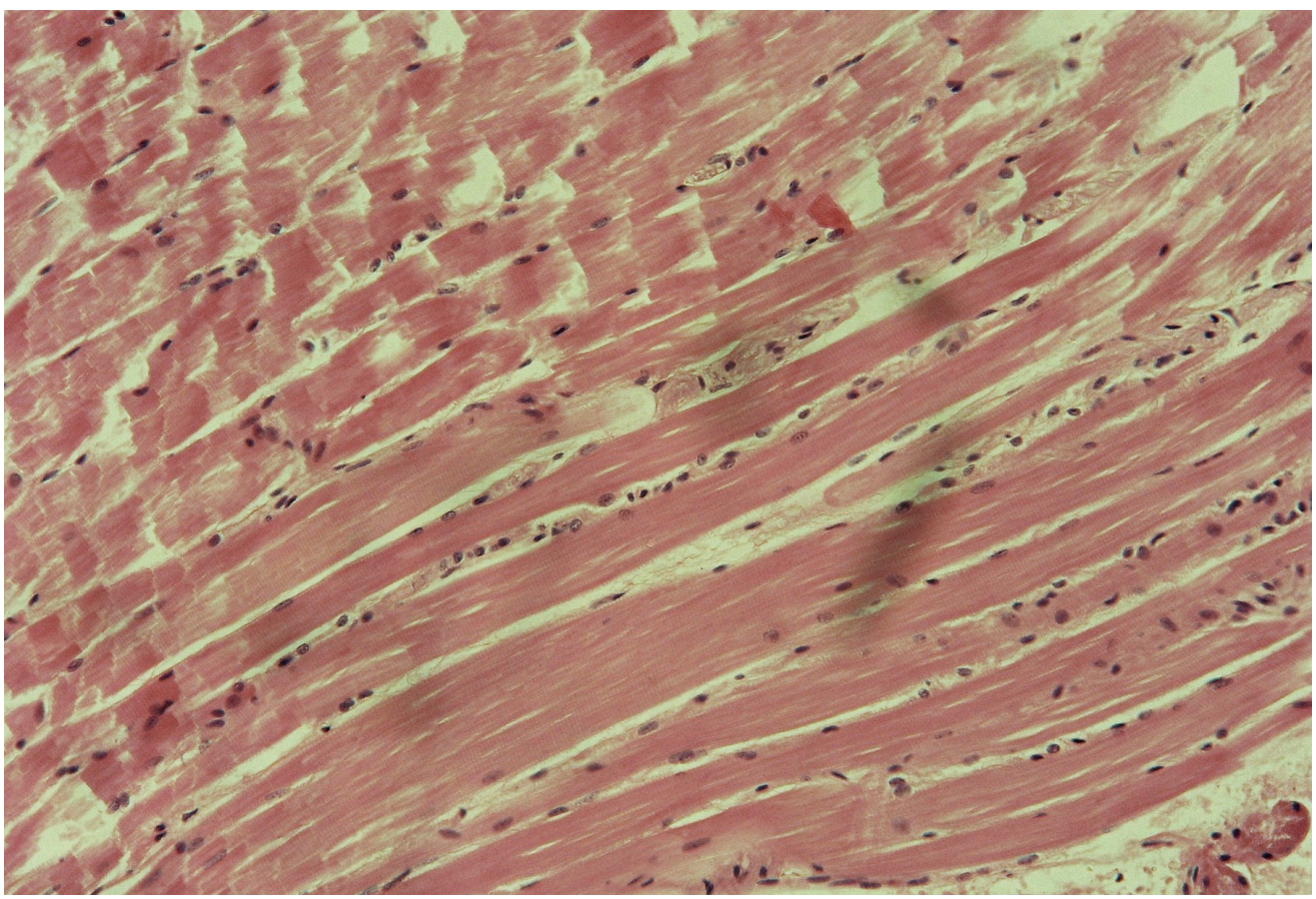

Figura 2. Microscopia de luz. Corte histológico do músculo pterigóideo medial de rato com envelhecimento. Revela o tecido conjuntivo entre as fibras musculares formando feixes orientados em várias direções. 64 X Coloração: Hematoxilina -Eosina.

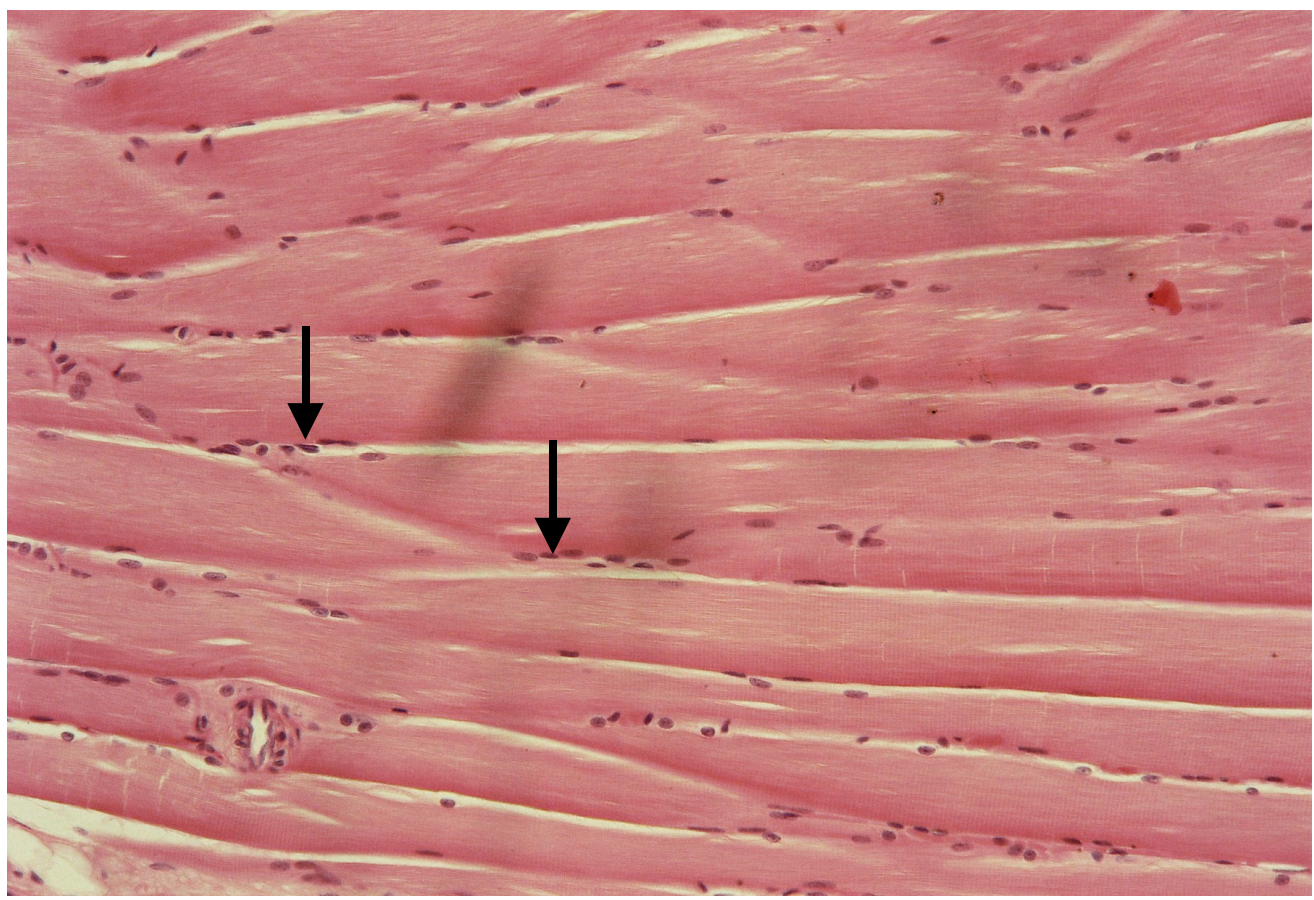

Figura 3. Microscopia de luz. Corte histológico do músculo pterigóideo medial de rato com envelhecimento. Revela a presença de núcleos (setas) na porção periférica do sarcoplasma. 120X Coloração: Hematoxilina -Eosina. 
Na figura 4 notaram-se as áreas de fixação dos feixes de tecido conjuntivo na superfície óssea da mandíbula assim como a presença de vasos sangüíneos e fibroblastos.

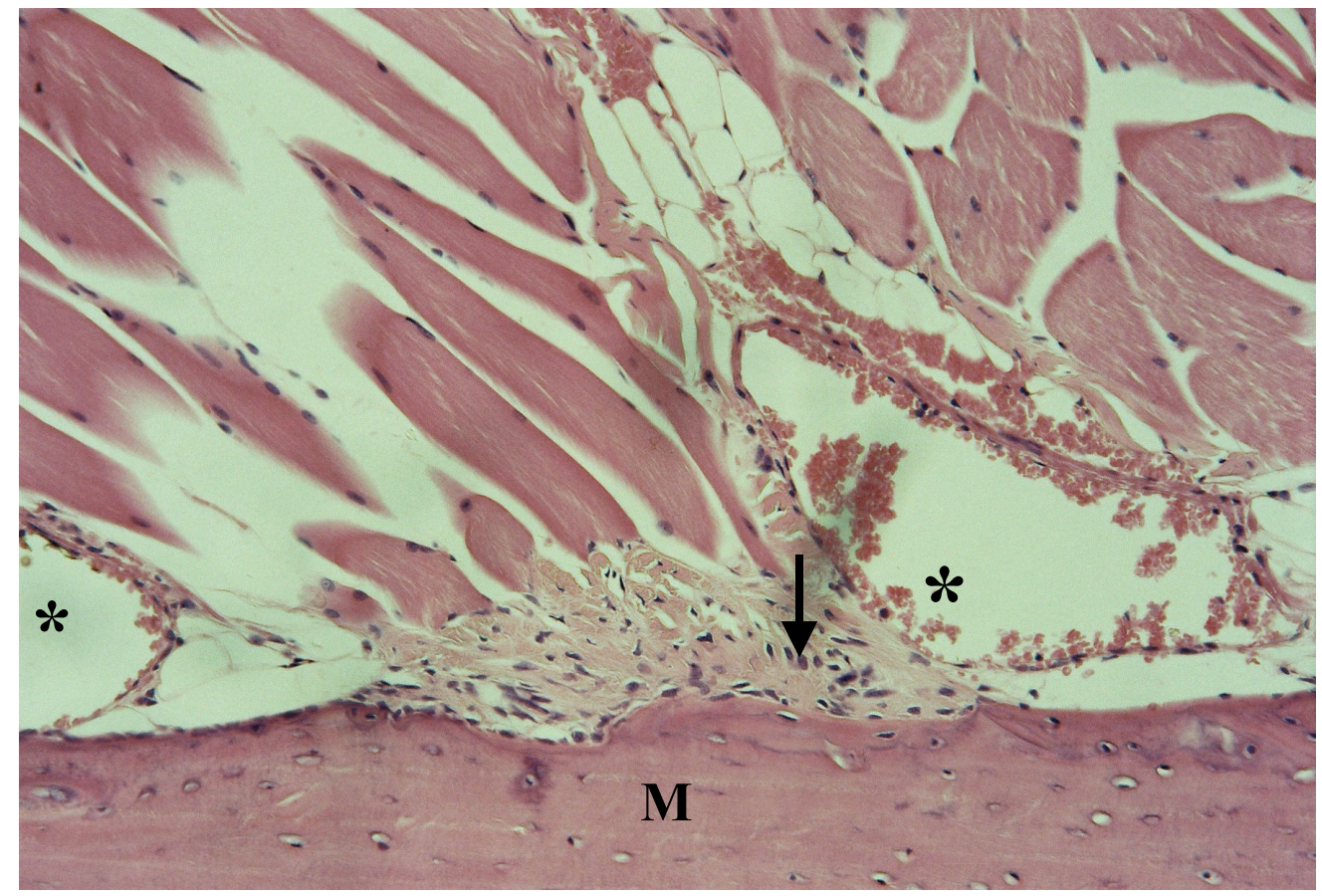

Figura 4. Microscopia de luz. Corte histológico do músculo pterigóideo medial de rato com envelhecimento. Mostra a junção da camada muscular e a superfície medial do ramo da mandíbula $(\mathrm{M})$ através de fibras de tecido conjuntivo. No interior do tecido conjuntivo verifica-se a presença de numerosos fibroblastos (seta) e vasos sangüíneos $\left(^{*}\right.$ ) contendo as hemácias. 120X Coloração: Hematoxilina-Eosina.

O tecido conjuntivo que reveste as fibras musculares foi evidenciado em aspectos azuis corados pelo método de Azo-Carmin (Fig. 5 e 6). Segmentos de capilares contendo hemáceas foram notados entre as fibras musculares e os feixes de colágeno junto à superfície de inserção óssea (Fig. 7). O tecido conjuntivo aderente ao tecido ósseo e intratrabecular revelou aspectos histológicos densos corados em azul e na região mais próxima às fibras musculares, um tecido conjuntivo menos denso, mostrando as inserções de fibras musculares (Fig. 7). 


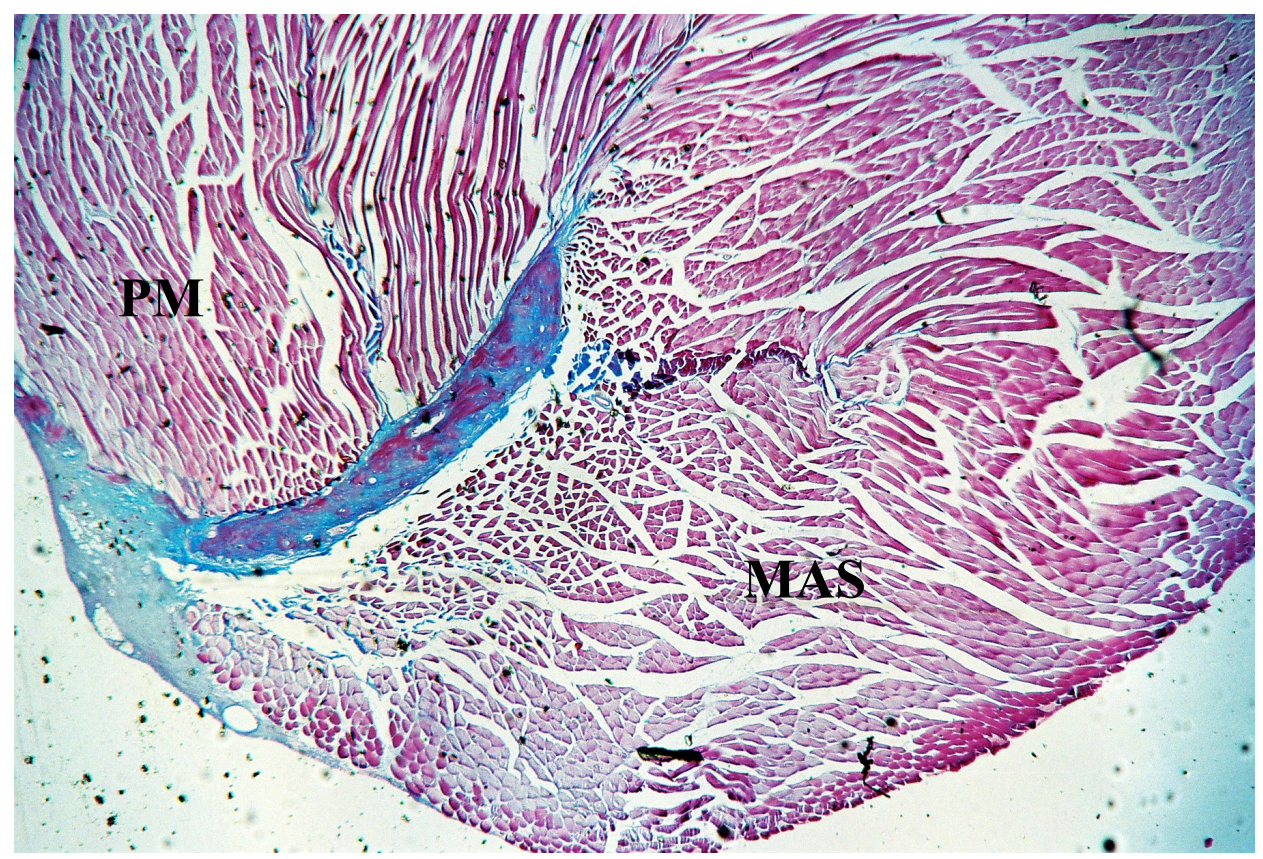

Figura 5. Em pequeno aumento, revela o tecido conjuntivo que reveste as fibras musculares do pterigóideo medial (PM) e do masseter (MAS). Observam-se fibras musculares e feixes de colágeno junto à superfície de inserção óssea. 25X. Coloração: Azo-Carmin.

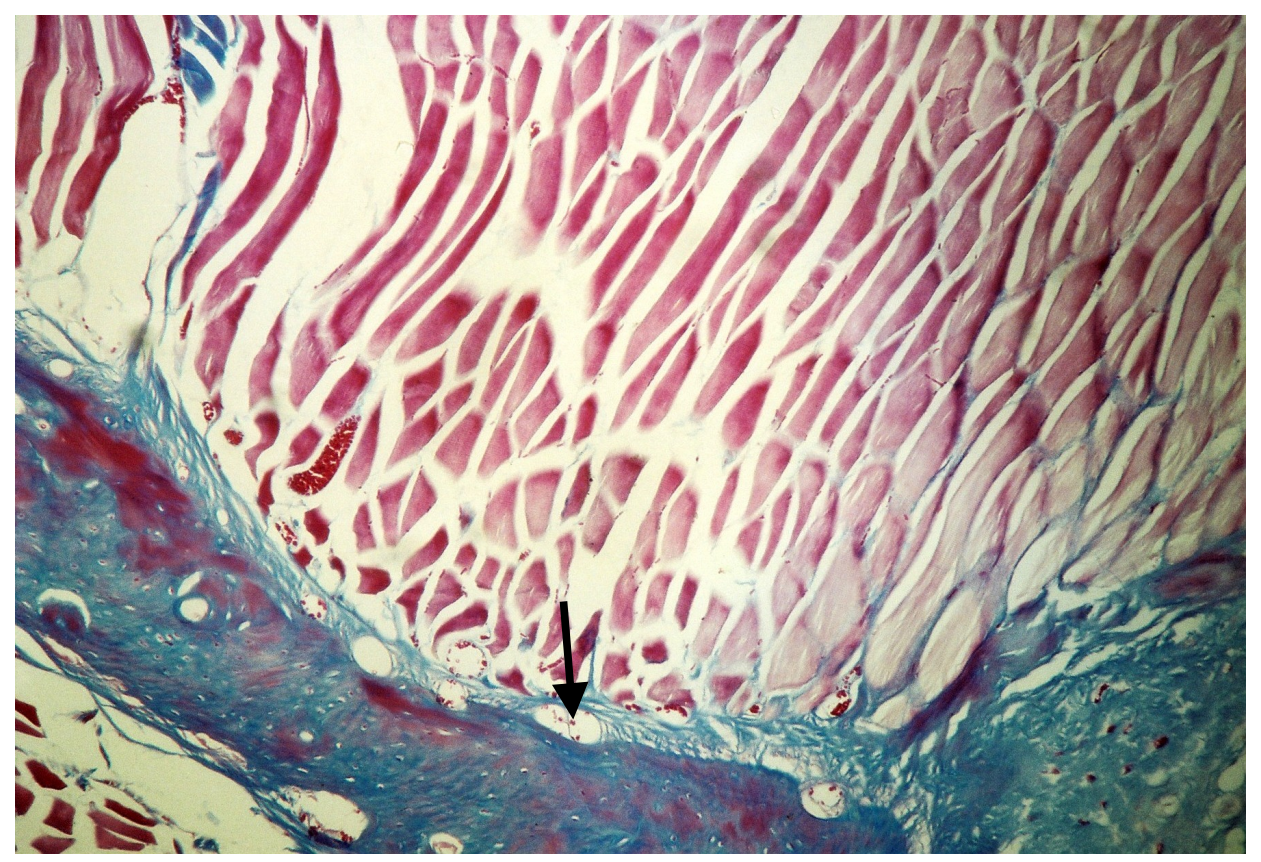

Figura 6. Corte histológico do músculo pterigóideo medial de rato com envelhecimento. Mostra o tecido conjuntivo aderente ao tecido ósseo densamente corado em azul e tecido conjuntivo, revelando as inserções de fibras musculares e capilares contendo numerosas hemácias (seta). 64X Coloração: Azo-Carmin. 


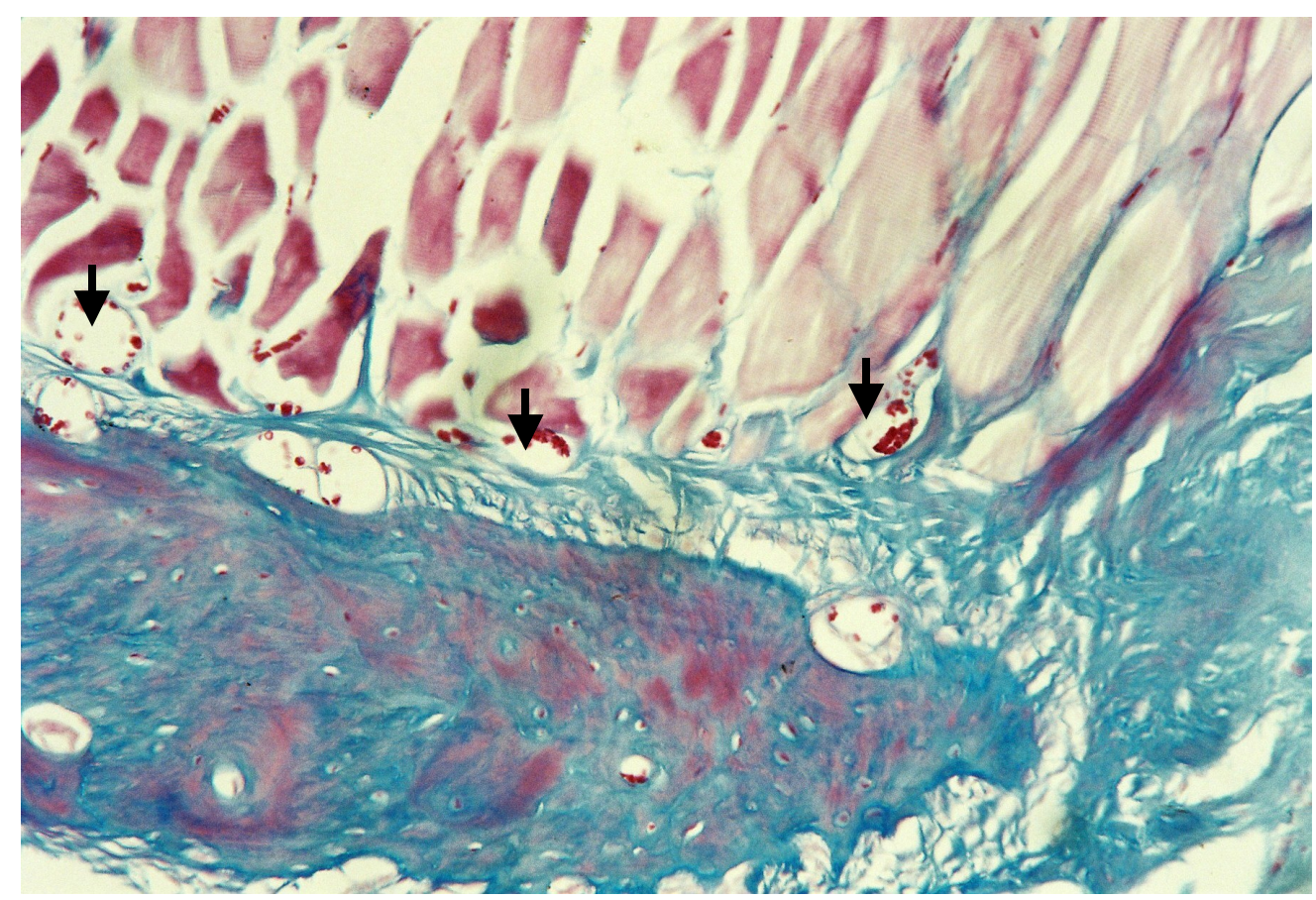

Figura 7. Microscopia de luz. Corte histológico do músculo pterigóideo medial de rato com envelhecimento. Evidencia as fibras musculares, vasos sanguíneos (setas) e tecido conjuntivo intensamente corado em azul. 120X Coloração: Azo-Carmin.

Entre as numerosas fibras musculares notam-se vasos sanguíneos e feixes de fibras nervosas (Fig. 7). No tecido conjuntivo, notam-se alguns capilares de diâmetros menores, cerca de 3 a 10 micrometros, e geralmente são localizados no espaço triangular formado pelo encontro de duas a três lâminas de sarcolemas e na área de inserção das fibras tendíneas.

Cortes corados pela solução de Picrosirius evidenciaram as fibras musculares e feixes de fibras colágenas corados em vermelho intenso junto à lâmina de tecido ósseo (Fig. 8). O tecido ósseo apresenta-se corado em vermelho evidenciando a parte de tecido conjuntivo (Fig. 9). Entre as fibras musculares notase o tecido conjuntivo corado em vermelho revelando a presença de endomísio das fibras musculares (Fig. 9).

O tecido conjuntivo que constitui o endomísio das fibras musculares é evidenciado em aspectos avermelhado coradas pela solução de Picrosirius (Fig. 9). Dependendo da direção do corte notam-se extensas faixas de tecido conjuntivo delimitando lojas onde contêm as fibras musculares. 


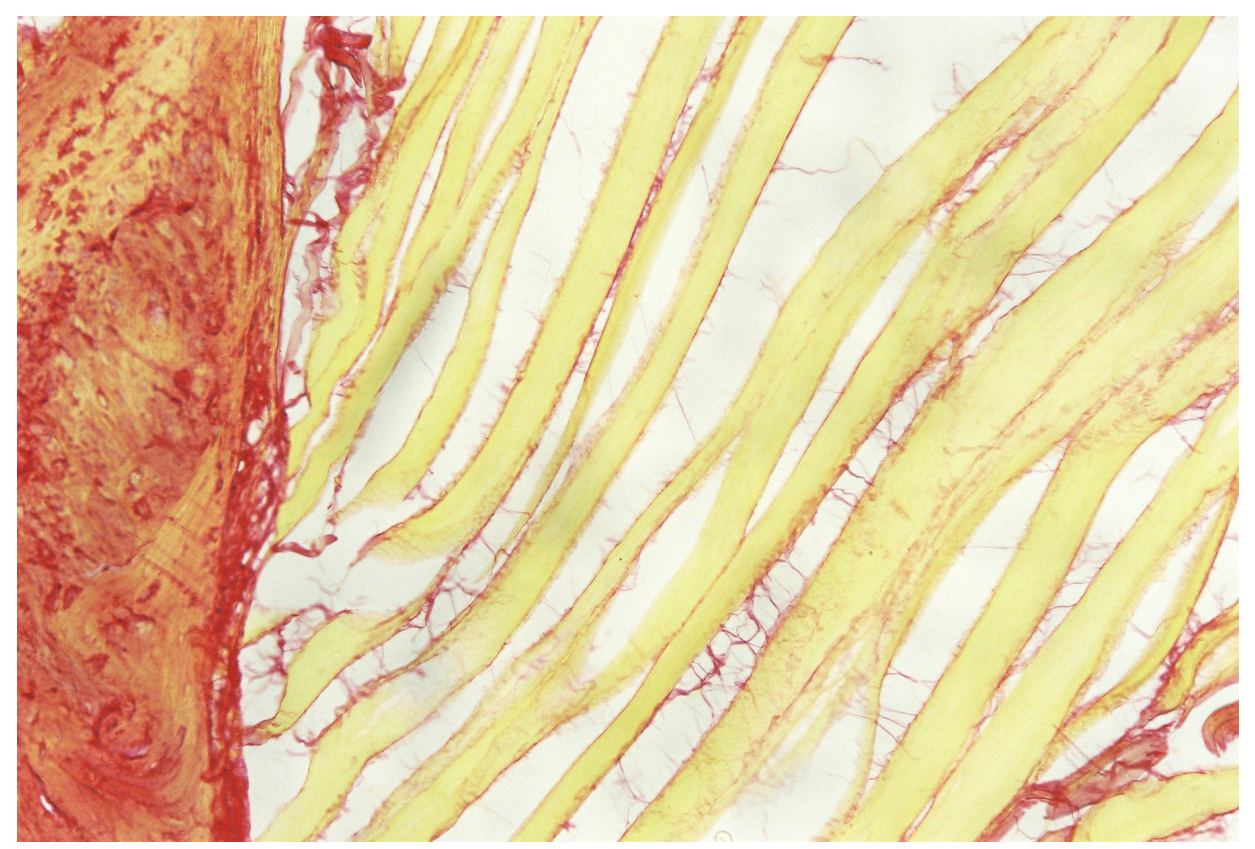

Figura. 8. Entre as fibras musculares dispostas longitudinalmente nota-se o tecido conjuntivo revelando a presença de endomísio de cada fibra muscular. O tecido conjuntivo do tecido ósseo é identificado em coloração avermelhada 120X Coloração: Picrosirius.

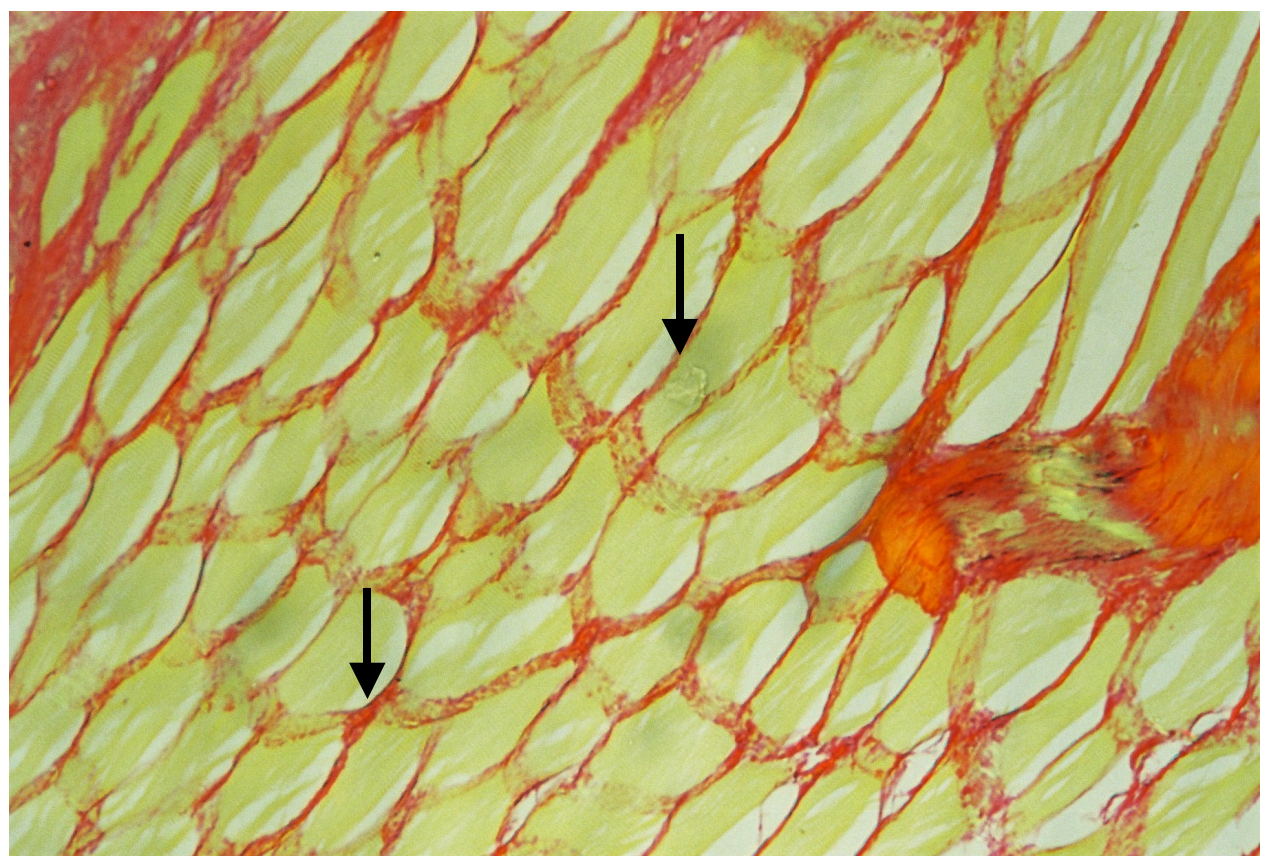

Figura 9. Nota-se o tecido conjuntivo do endomísio corado em vermelho (setas). Numerosas lojas circundadas por linhas vermelhas são claramente notadas. 120X Coloração: Picrosirius. 
Quando examinado sob luz polarizada observa-se a coloração pela birrefringência, os aspectos esverdeado e avermelhado, caracterizando a presença de fibras colágenas (Fig. 10 e 11).

Em maior aumento, pode-se notar que o tecido conjuntivo próximo ao tecido ósseo e no interior da camada muscular é intensamente corado em vermelho, caracterizando a presença de fibras colágenas (Fig. 11).

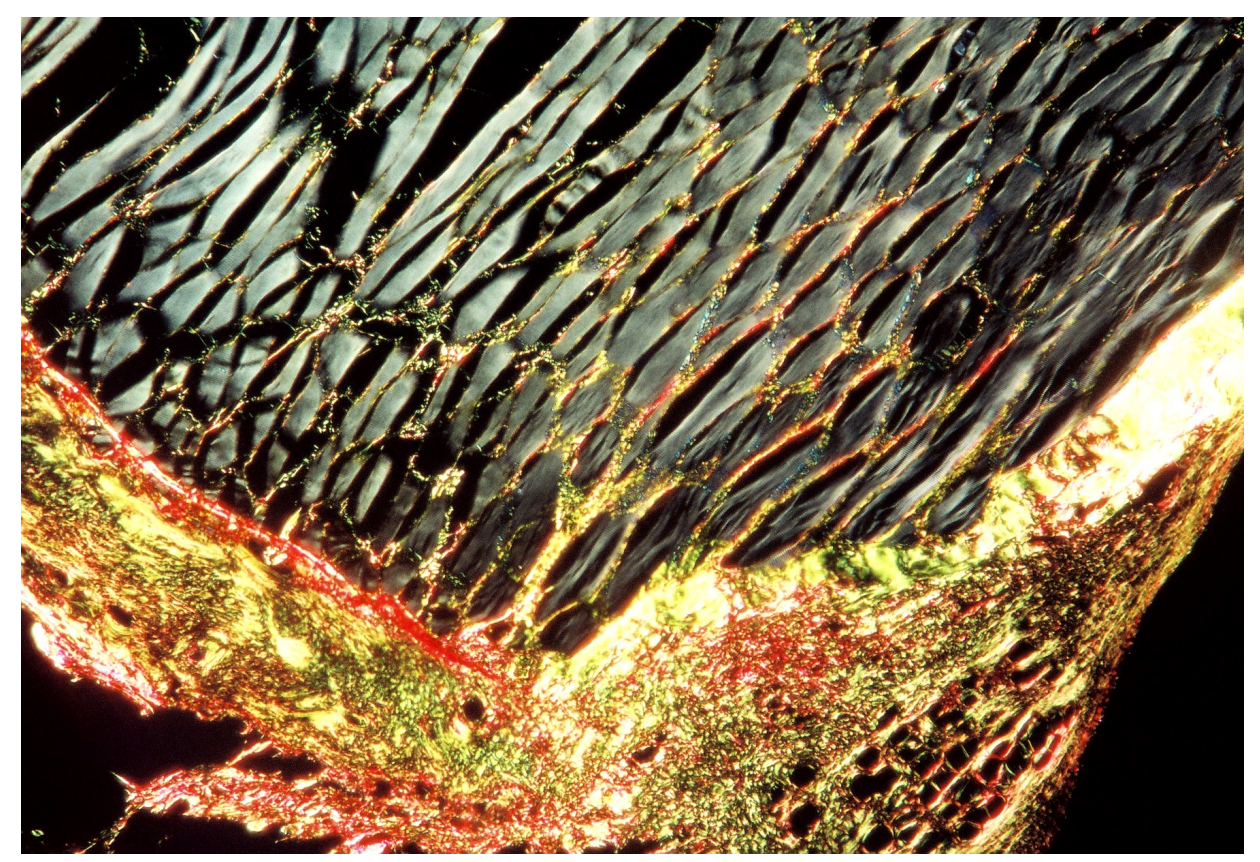

Figura 10. Corte examinado sob luz polarizada. Observam-se à coloração pela birrefringência os aspectos esverdeado e avermelhado caracterizando a presença de fibras colágenas. 64X Coloração: Picrosirius. 


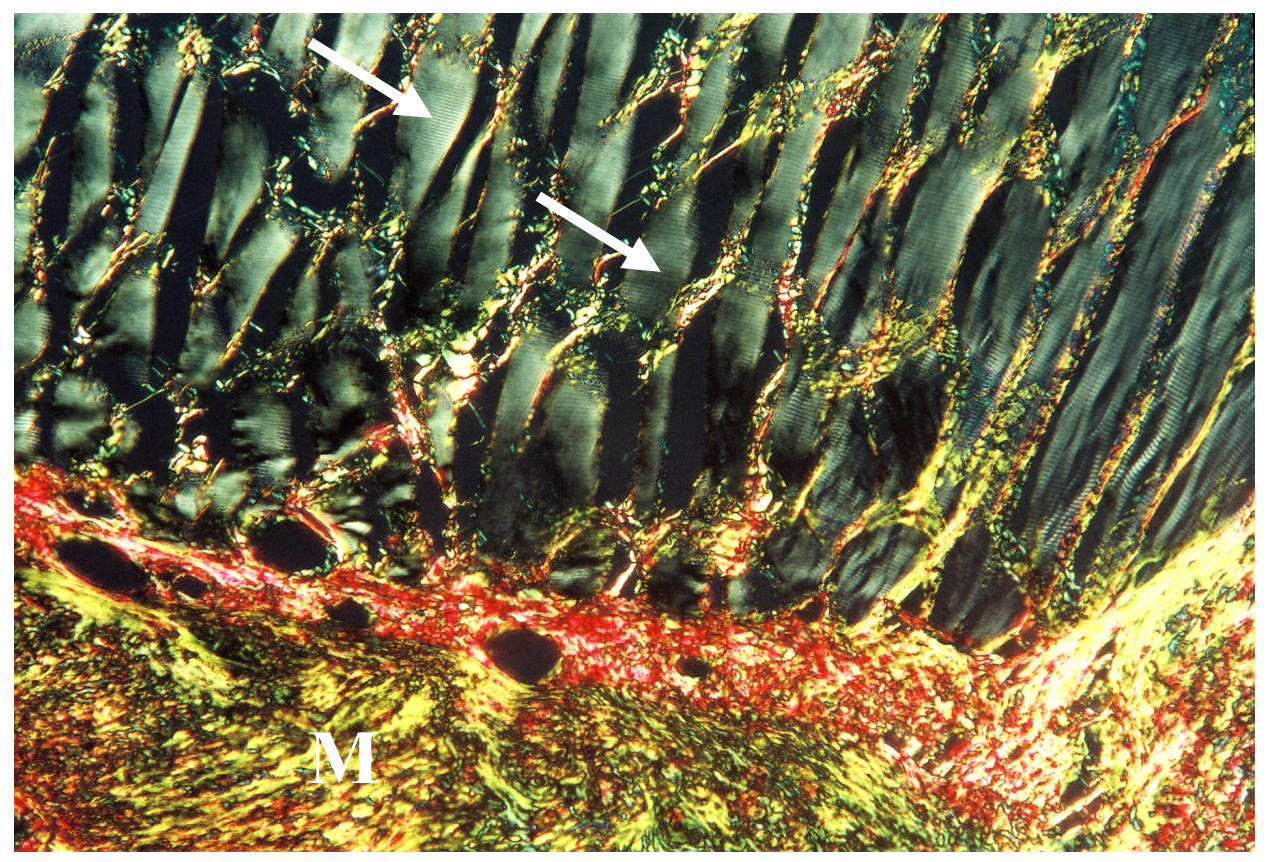

Figura 11. Fotomicrografia de luz polarizada. Observa-se a coloração esverdeada e avermelhada pela presença de fibras colágenas da superfície muscular (setas) e da mandíbula (M). As fibras musculares e o tecido conjuntivo do endomísio são notados nitidamente. 120X Coloração: Picrosirius.

A figura 12 evidencia uma faixa de tecido conjuntivo corado em vermelho intenso, representando as fibras colágenas e no interior da camada muscular fibras esverdeadas e vermelhas. Na superfície do tecido ósseo evidencia-se nitidamente a coloração das fibras colágenas (Fig. 12). 


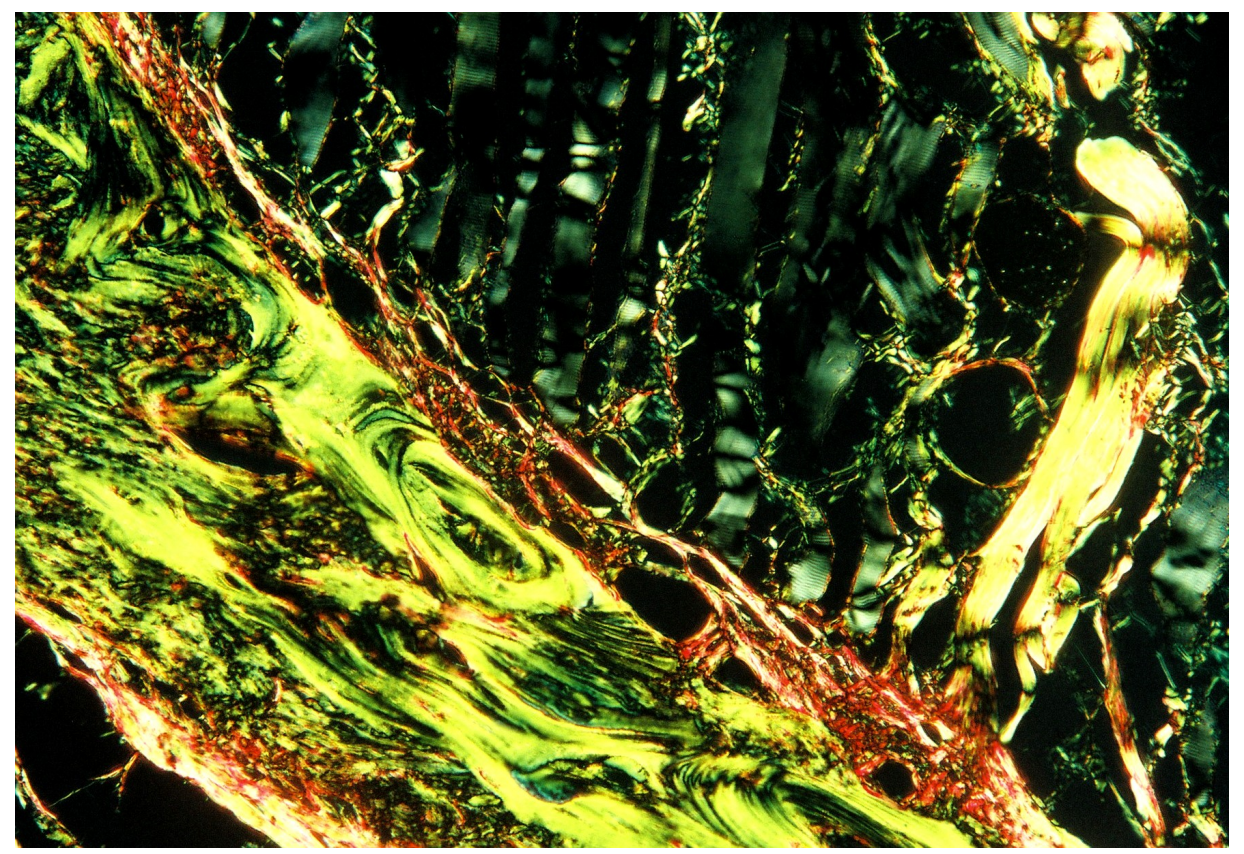

Figura 12. Fotomicrografia de luz polarizada. Mostra as lamelas do corpo da mandíbula evidenciando o tecido conjuntivo de coloração esverdeada e avermelhada na área de inserção, indicando a presença de fibras colágenas. 120X. Coloração: Picrosirius.

A observação ao microscópio eletrônico de varredura pôde demonstrar a área de inserção do músculo pterigóideo medial na superfície medial do ângulo da mandíbula (Fig. 13 e 14). Observaram-se claramente os forames nutrícios da face medial da mandíbula em diferentes aumentos (Fig. 15 e 16) e a presença do feixe de fibras colágenas da superfície óssea mandibular (Fig. 17). 


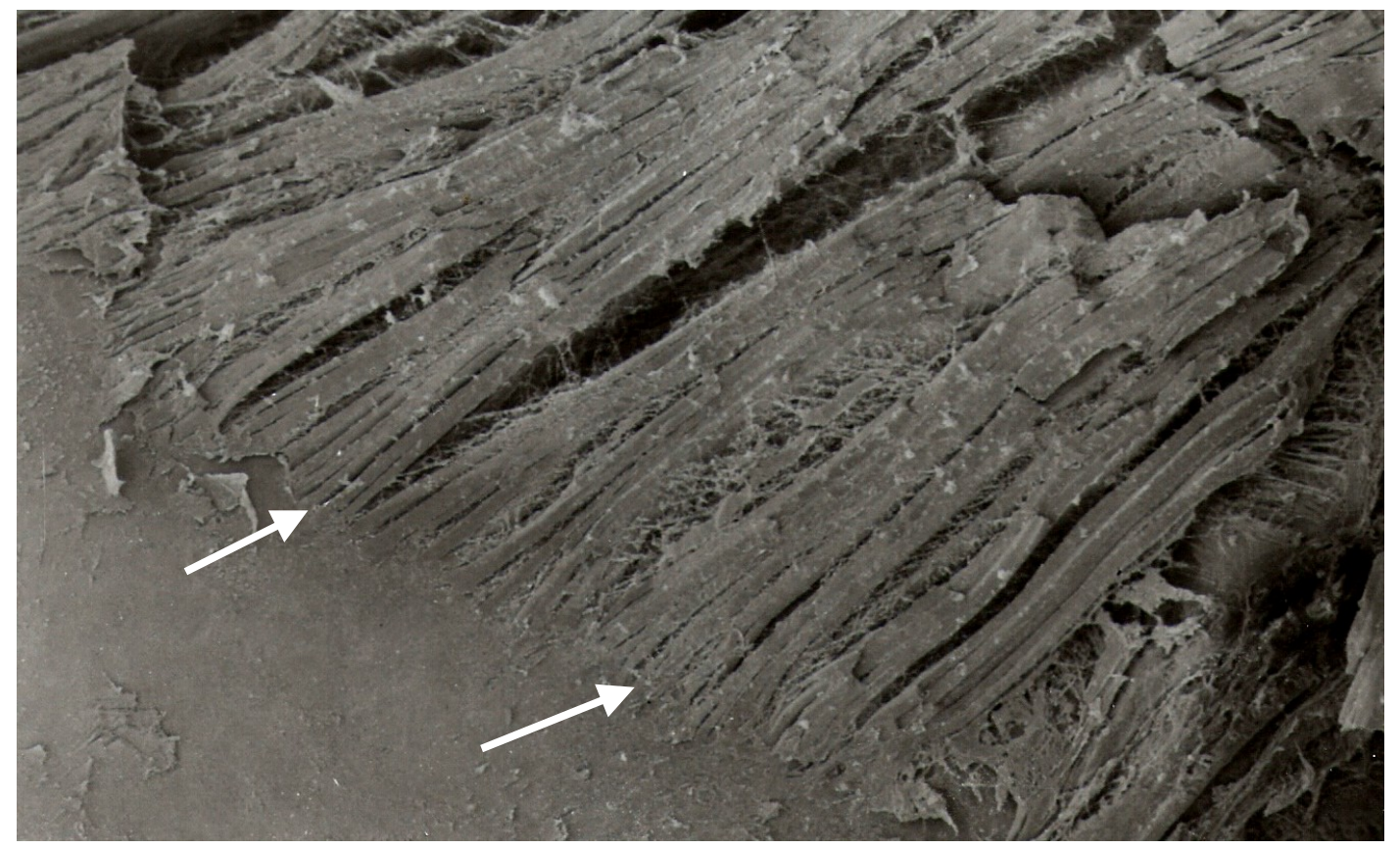

Figura 13. Microscopia eletrônica de varredura. Peça fixada em solução de Karnovsky modificada evidenciando a área de inserção do músculo pterigóideo medial na face interna do ângulo da mandíbula (setas). 30X.

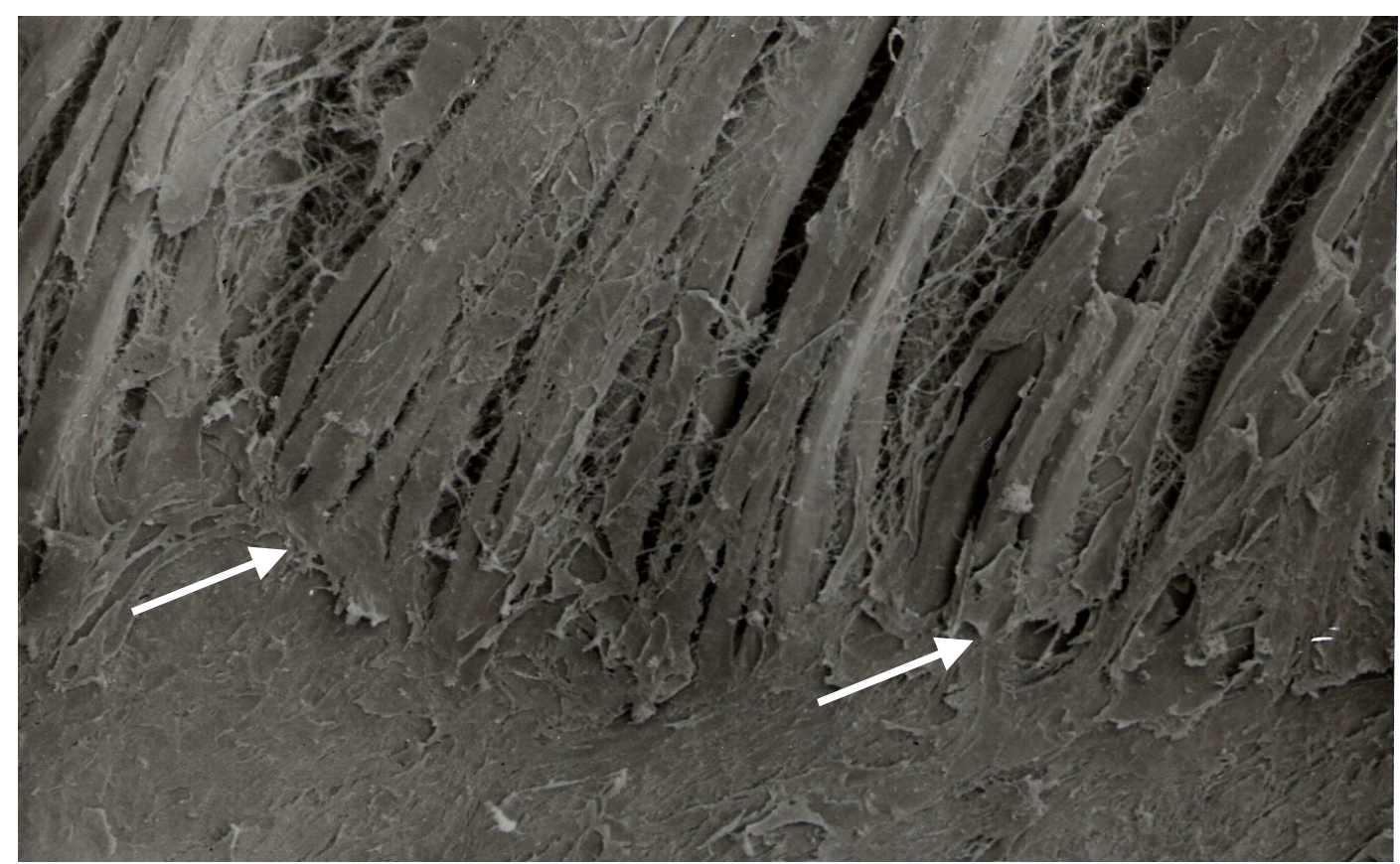

Figura 14. Microscopia eletrônica de varredura. Em maior aumento, observa-se o colágeno da área de inserção das fibras musculares do pterigóideo medial de rato com envelhecimento na superfície óssea da mandíbula (setas). 100X. 


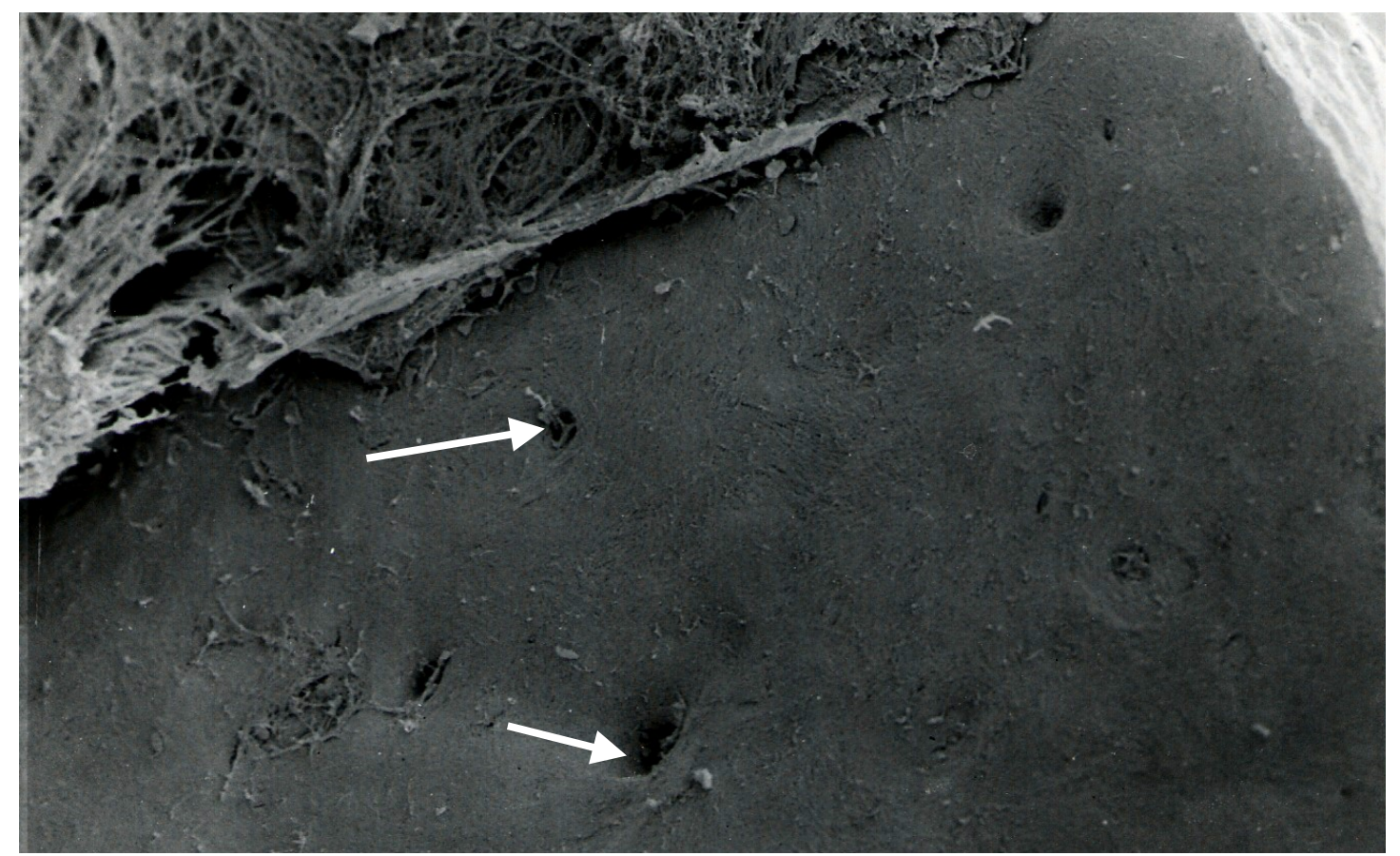

Figura 15. Microscopia eletrônica de varredura. Os forames nutrícios são nitidamente observados na superfície óssea mandibular (setas). 200X.

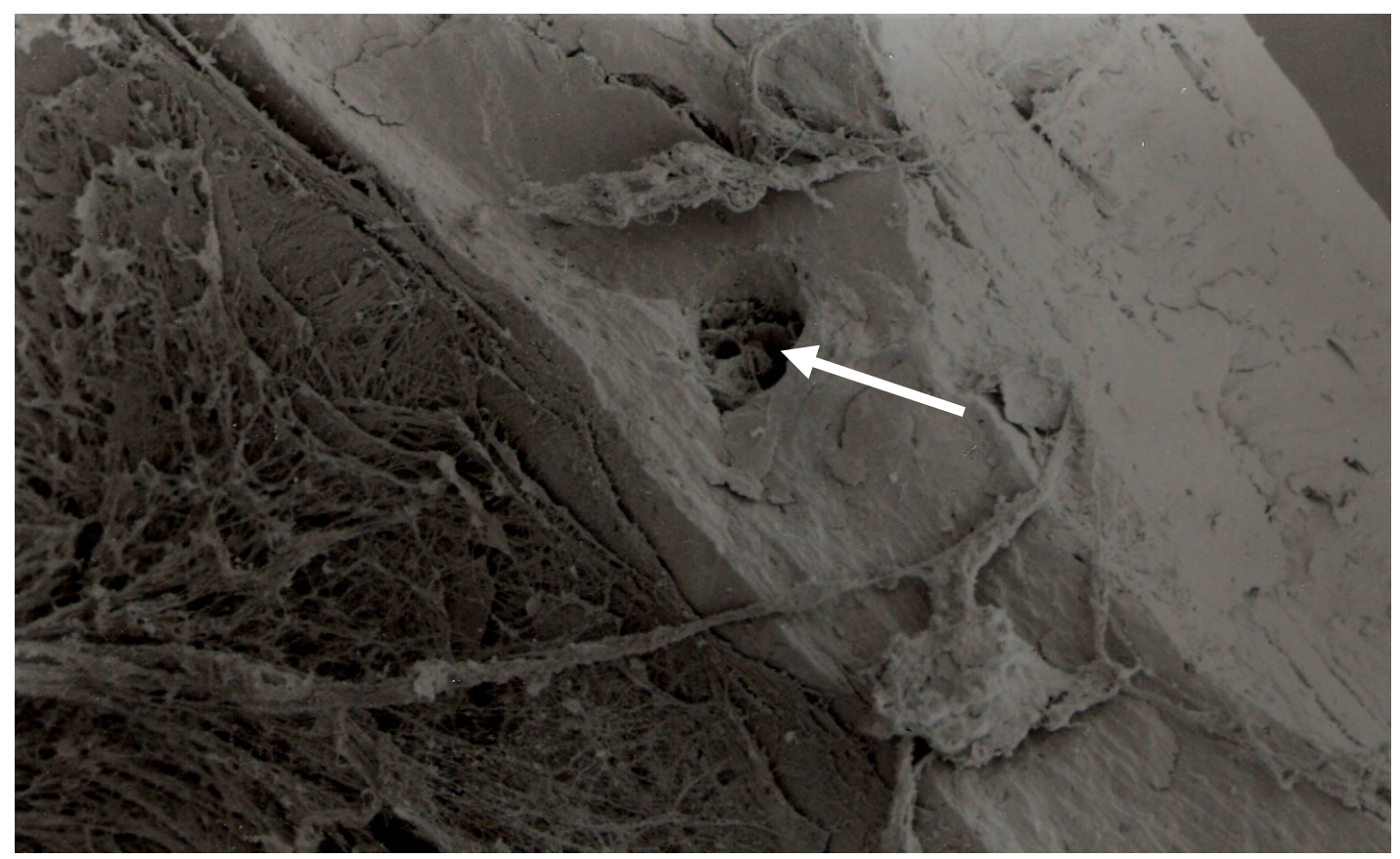

Figura 16. Microscopia eletrônica de varredura. Observa-se um forame nutrício (seta) em maior aumento na face medial da mandíbula, próximo à área de inserção das fibras do músculo pterigóideo medial com envelhecimento. 100X. 


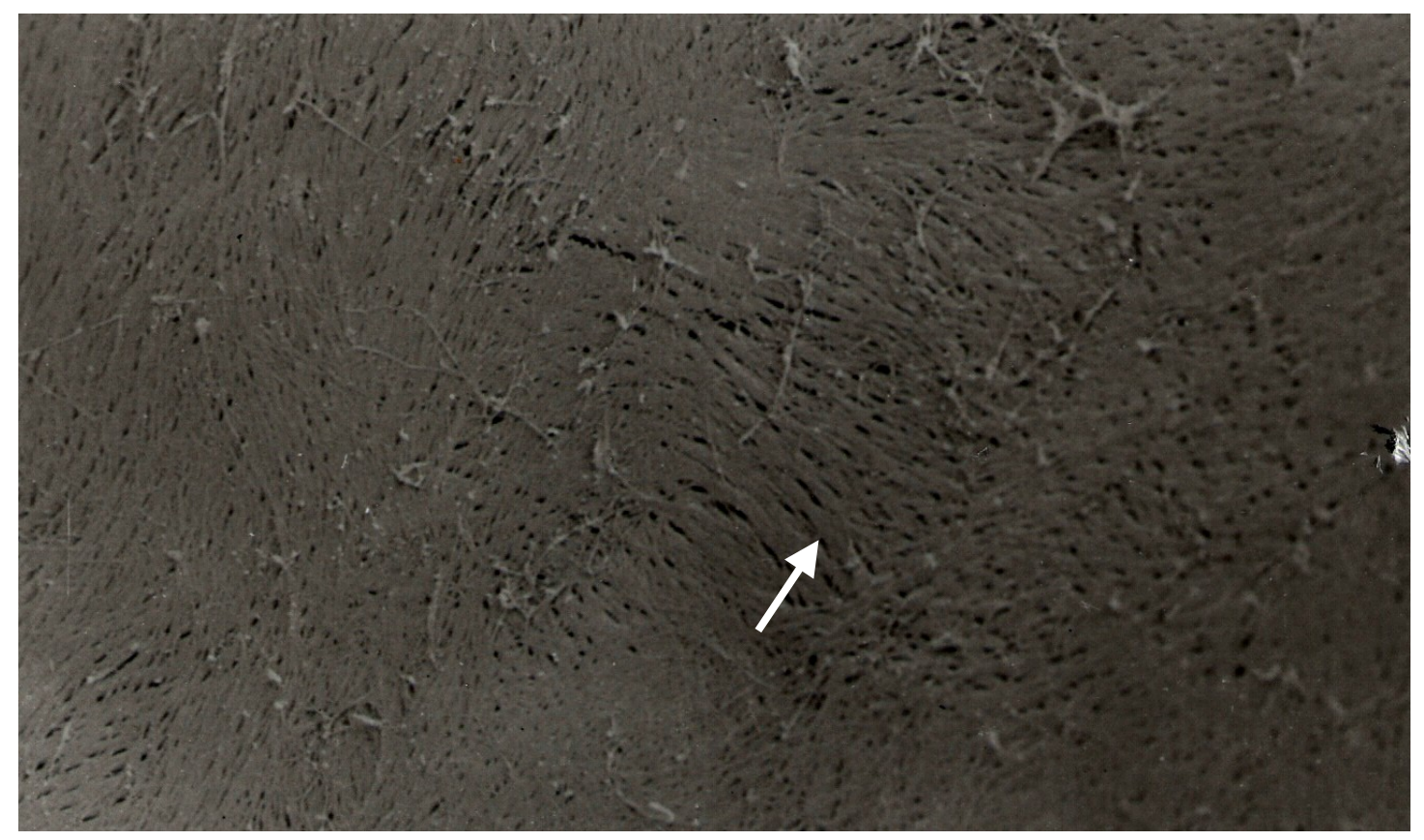

Figura 17. Microscopia eletrônica de varredura. A peça tratada com solução de $\mathrm{NaOH}$ mostra nitidamente os feixes de fibras colágenas presentes no tecido ósseo mandibular (seta). 800X.

Em maior aumento, notaram-se os feixes de fibras musculares dispostos longitudinalmente, entremeados por tecido conjuntivo (Fig. 18 e 19).

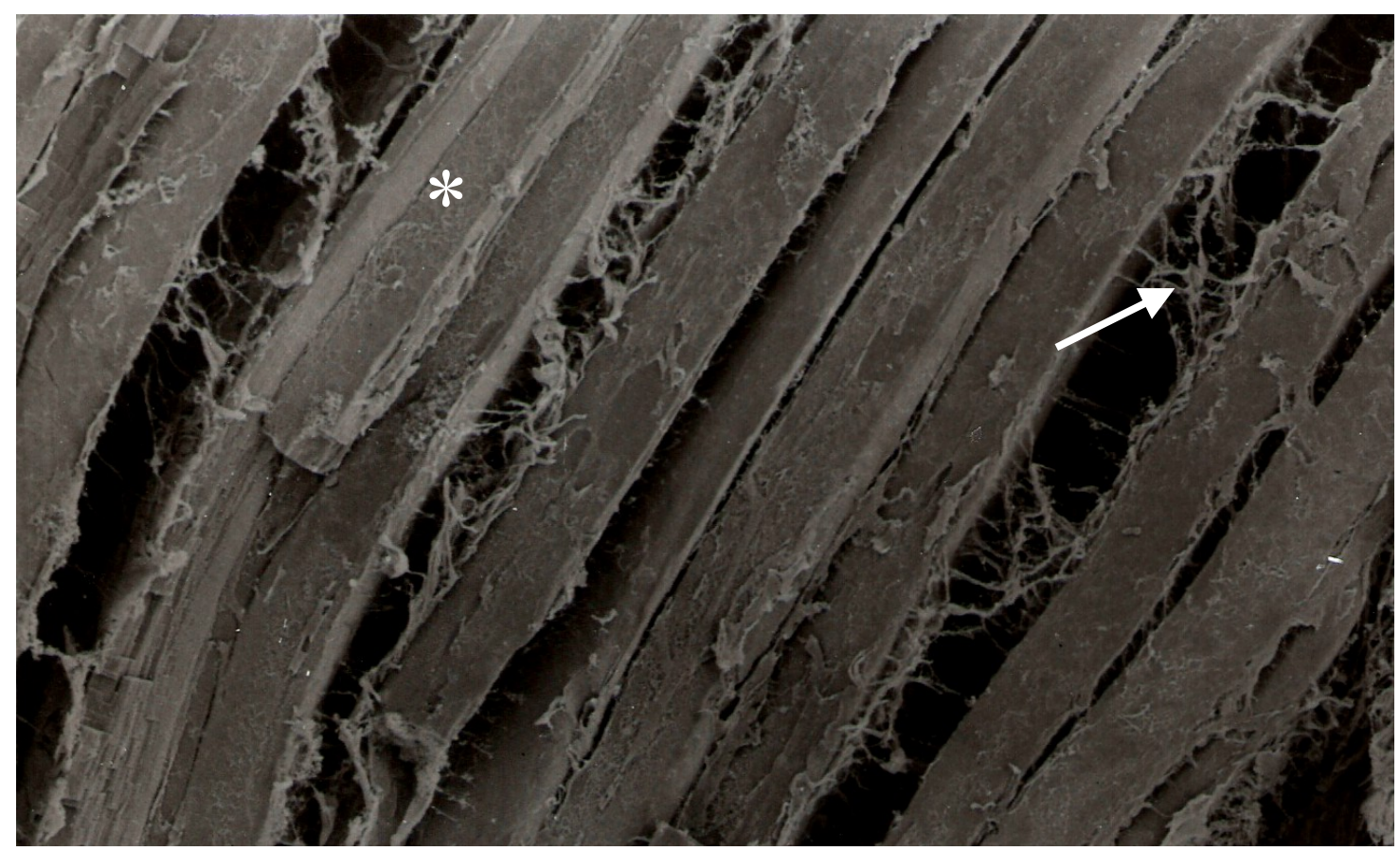

Figura 18. Microscopia eletrônica de varredura. Podem-se observar as fibras musculares dispostas longitudinalmente $\left({ }^{*}\right)$ e o tecido colágeno (seta) presente entre as fibras. $200 \mathrm{X}$. 


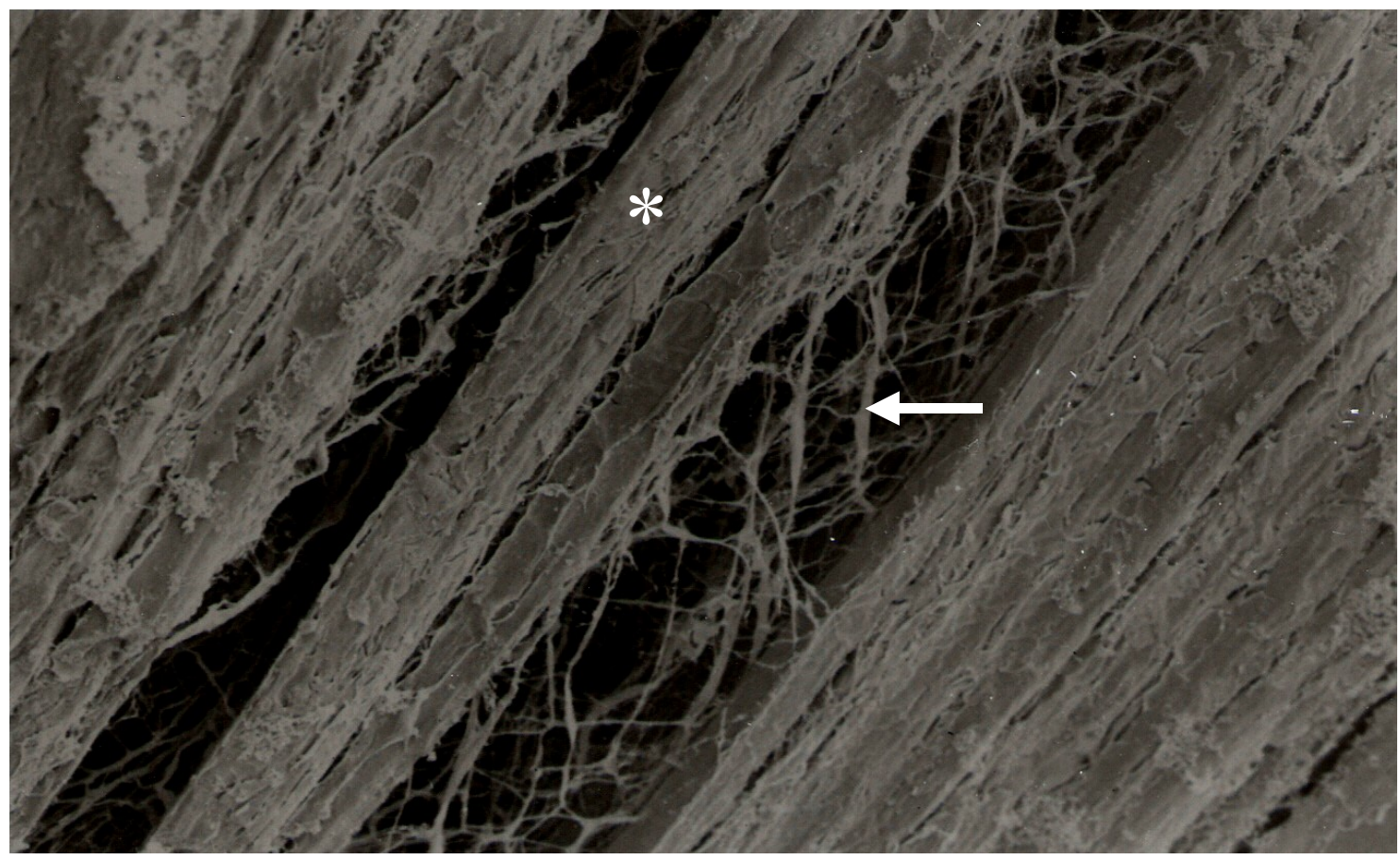

Figura 19. Microscopia eletrônica de varredura. Notam-se as redes de fibras colágenas (seta) entremeando as fibras do músculo pterigóideo medial dispostas longitudinalmente $\left(^{*}\right)$. $200 X$.

Nas fibras musculares fraturadas longitudinalmente, foi possível observar as estriações presentes características das fibras musculares esqueléticas (Fig. 20).

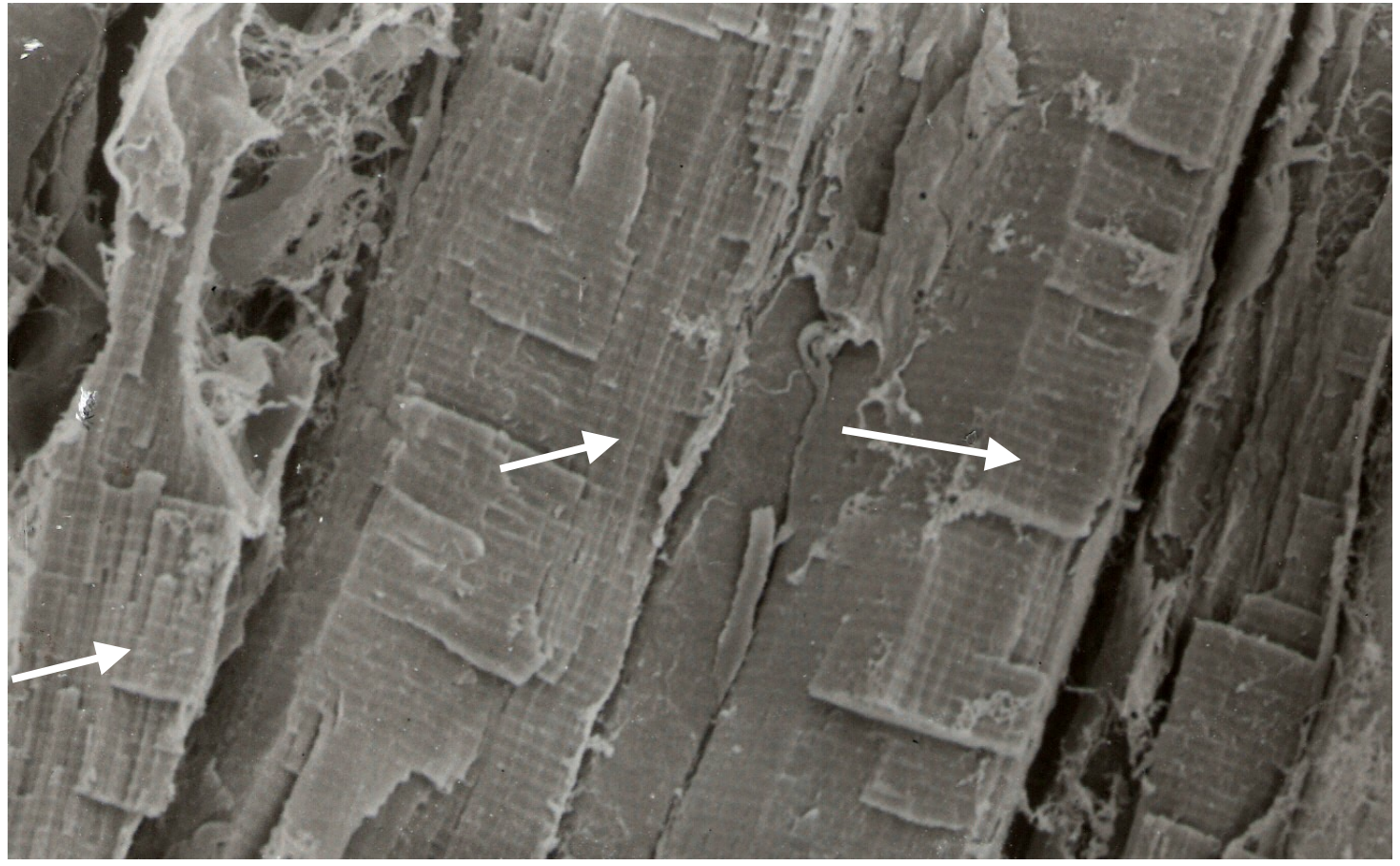

Figura 20. Microscopia eletrônica de varredura. Mostra a fibra muscular em corte longitudinal evidenciando as estriações (setas) características dos músculos esqueléticos. 800X. 
Nas amostras tratadas com solução de $\mathrm{NaOH}$, as células musculares foram removidas evidenciando-se o tecido conjuntivo do endomísio em disposição original (Fig. 21). Em maior aumento, pode-se notar claramente a rede de fibras colágenas da parede interna de cada fibra muscular (Fig. 22).

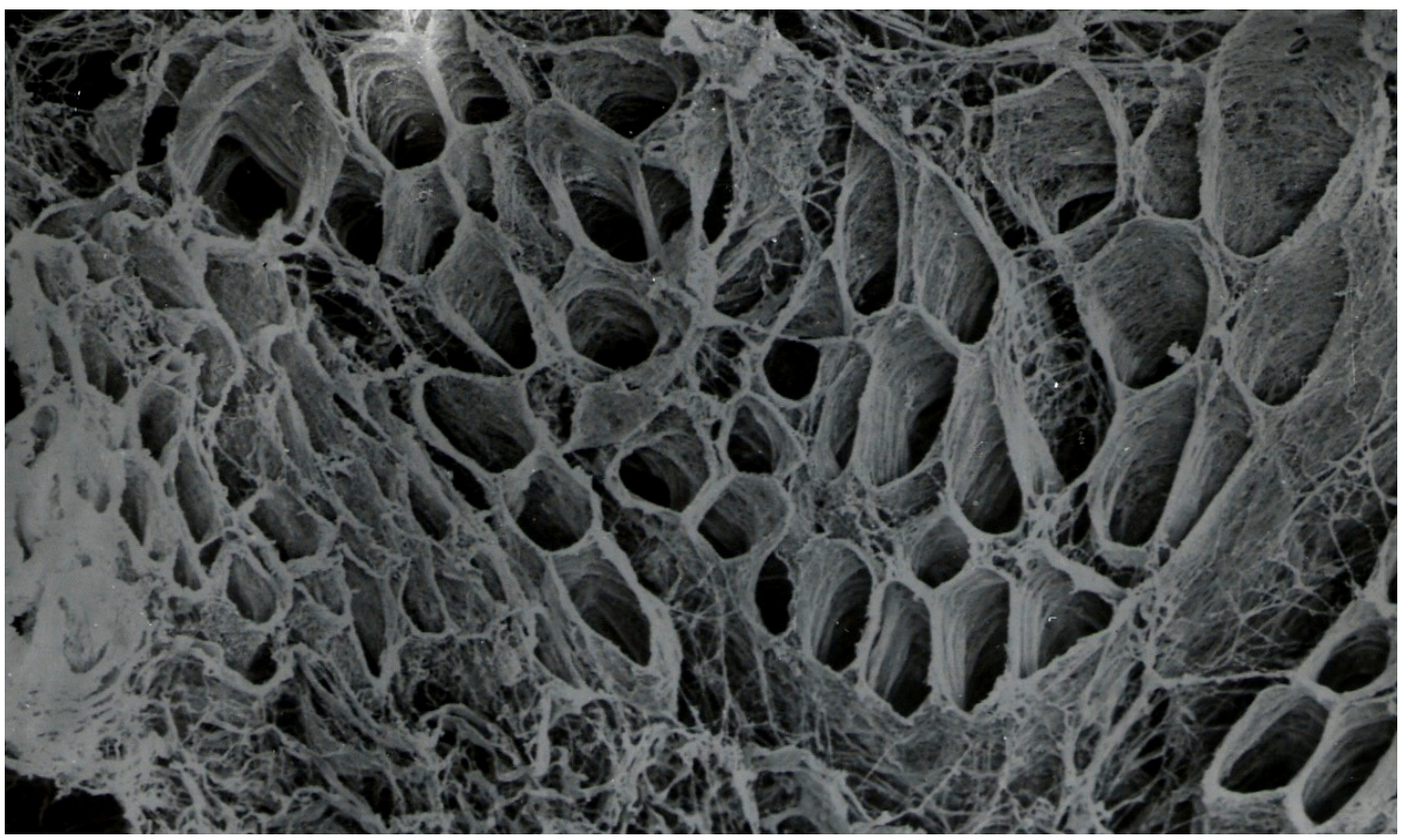

Figura 21. Microscopia eletrônica de varredura. Músculo pterigóideo medial de rato com envelhecimento tratado com solução de $\mathrm{NaOH}$, evidenciando o endomísio que envolve cada fibra muscular. 250X. 


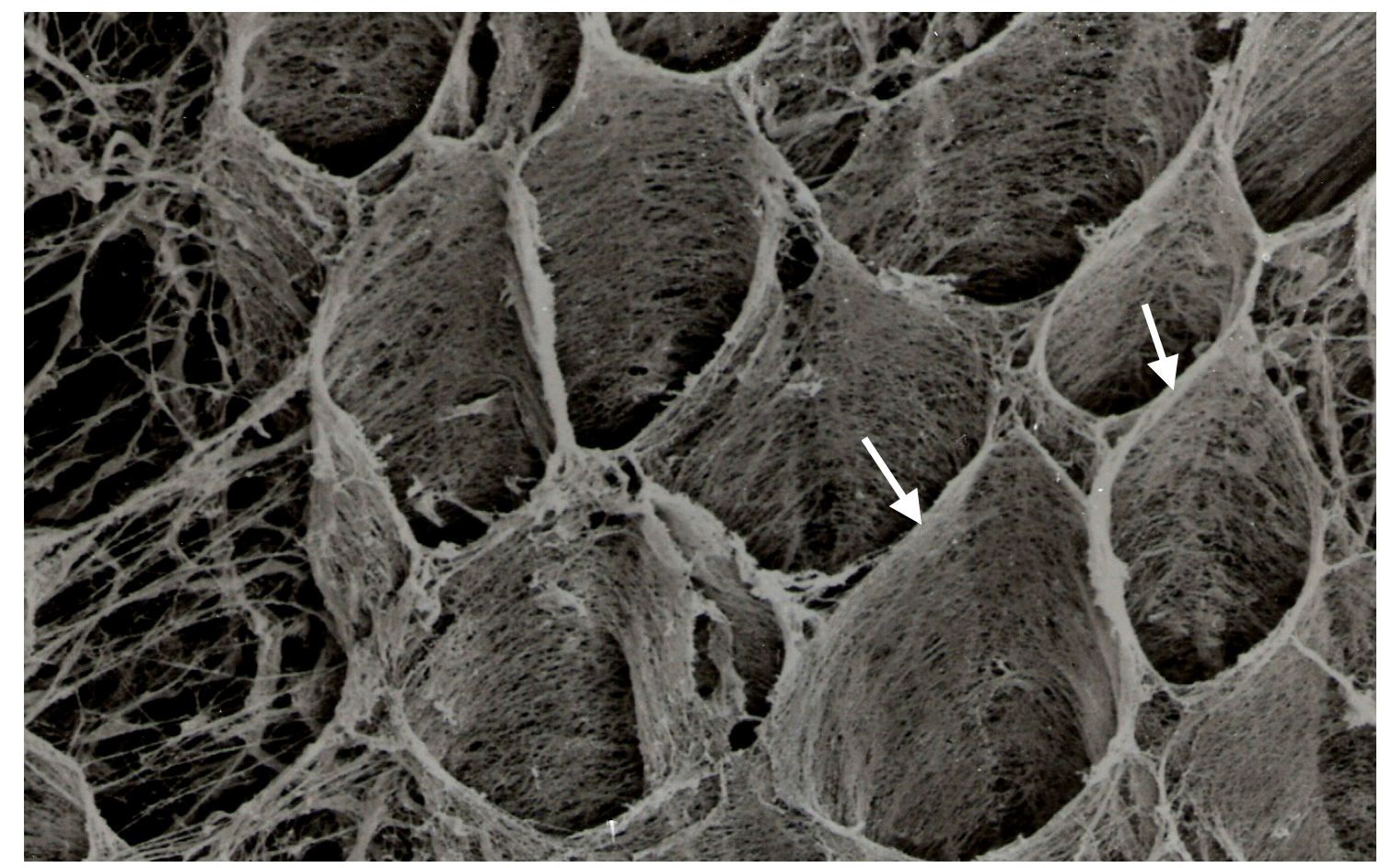

Figura 22. Microscopia eletrônica de varredura. Amostra tratada com solução de $\mathrm{NaOH}$. Revela, em maior aumento, a rede de fibras colágenas do endomísio (setas). 500X.

Os cortes ultrafinos examinados ao microscópio eletrônico de transmissão revelaram o aspecto geral das fibras musculares. Podem-se notar claramente as partes sarcoplasmáticas de três fibras musculares entremeadas de um capilar contendo a hemácia (Fig. 23). Verifica-se que o citoplasma da célula muscular apresenta um núcleo alongado e feixes de fibras colágenas junto à lâmina basal da membrana sarcoplasmática (Fig. 23). 


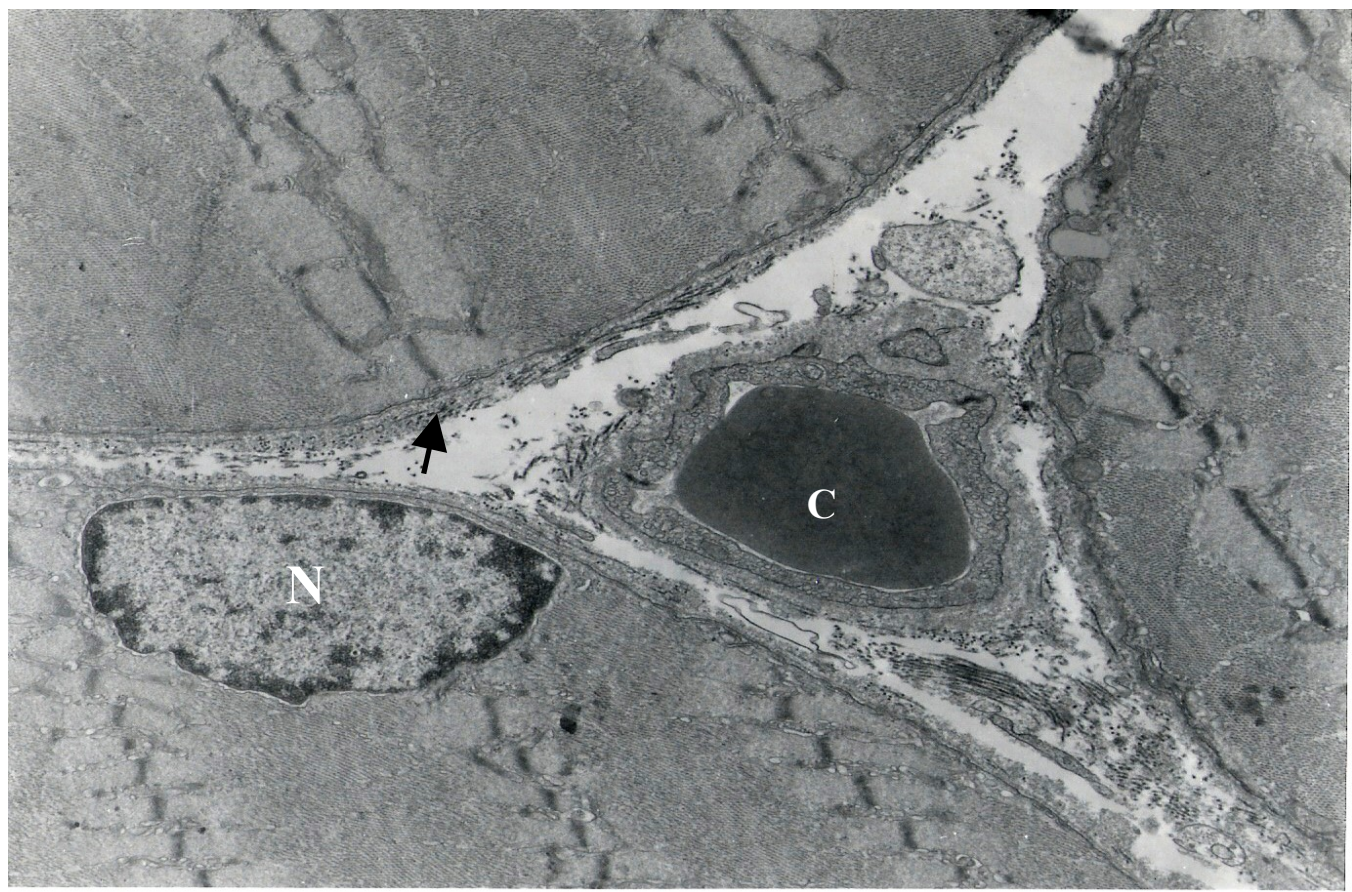

Figura 23. Microscopia eletrônica de transmissão. Músculo pterigóideo medial de rato com envelhecimento fixado em solução de Karnovsky modificada, pós-fixada em tetróxido de ósmio e incluída em resina Spurr. Mostra o aspecto de uma parte da camada muscular, evidenciando o sarcoplasma de três fibras musculares entremeadas de um capilar sangüíneo (C). Nota-se o citoplasma da célula muscular contendo um núcleo alongado $(\mathrm{N})$ e feixes de fibras colágenas (seta) junto à lâmina basal do sarcolema. 12.000X.

Além disso, evidencia o sarcoplasma da célula muscular com o núcleo alongado e disposição de mitocôndrias. O envoltório é formado por feixes de fibras colágenas e a presença de prolongamentos citoplasmáticos de fibroblasto é notada (Fig. 24). O sarcolema apresenta na sua face externa a lâmina basal e, na face interna, estruturas filamentosas e vesículas pinocíticas (cavéolas) (Fig.24). Os detalhes de mitocôndrias, o sarcolema e as fibras colágenas são notados na figura 24. 


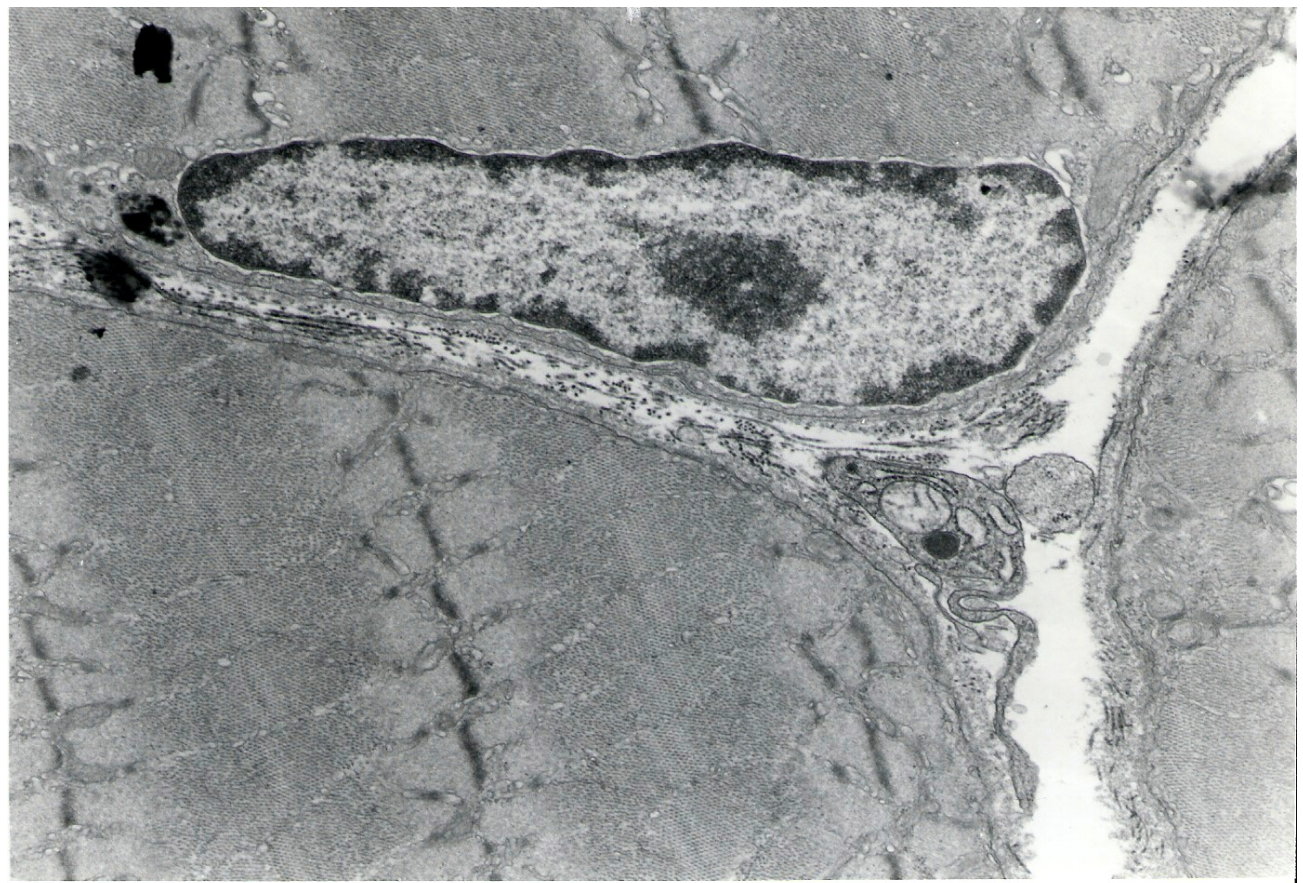

Figura 24. Microscopia eletrônica de transmissão. Peça fixada em solução de Karnovsky modificada, pós-fixada em tetróxido de ósmio e incluída em resina Spurr. Mostra o citoplasma da célula muscular, revelando o núcleo na porção periférica e feixes de miofibrilas entremeadas de mitocôndrias. 15.000X.

Geralmente, os feixes de miofibrilas são entremeados de mitocôndrias. Na porção periférica do sarcoplasma existe um acúmulo de mitocôndrias de vários tamanhos (Fig. 25 e 26). 


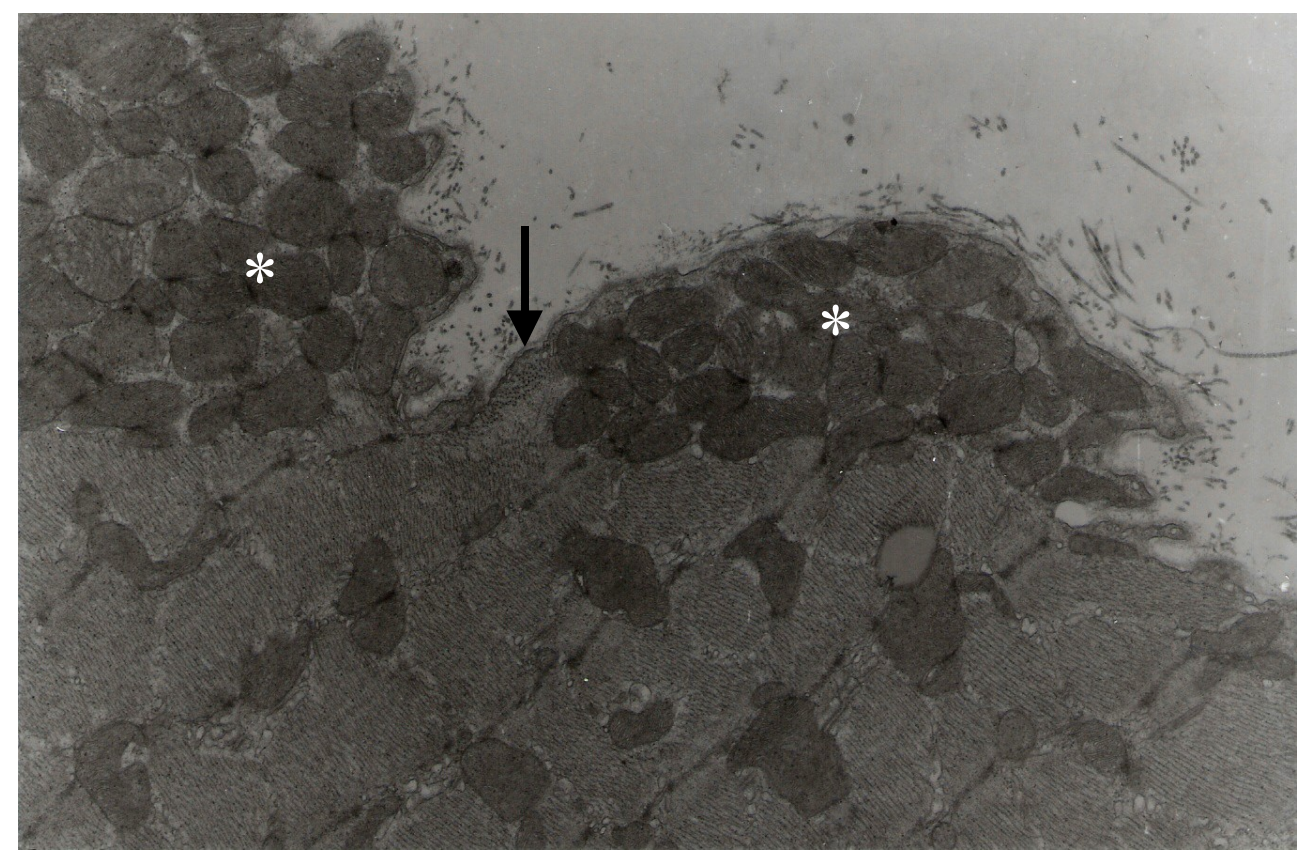

Figura 25. Microscopia eletrônica de transmissão. Peça fixada em solução de Karnovsky modificada, pós-fixada em tetróxido de ósmio e incluída em resina Spurr. Revela o grupamento de mitocôndrias $\left({ }^{*}\right)$ na porção periférica do sarcoplasma. A lâmina basal é notada na superfície da célula (seta). 7.500X.

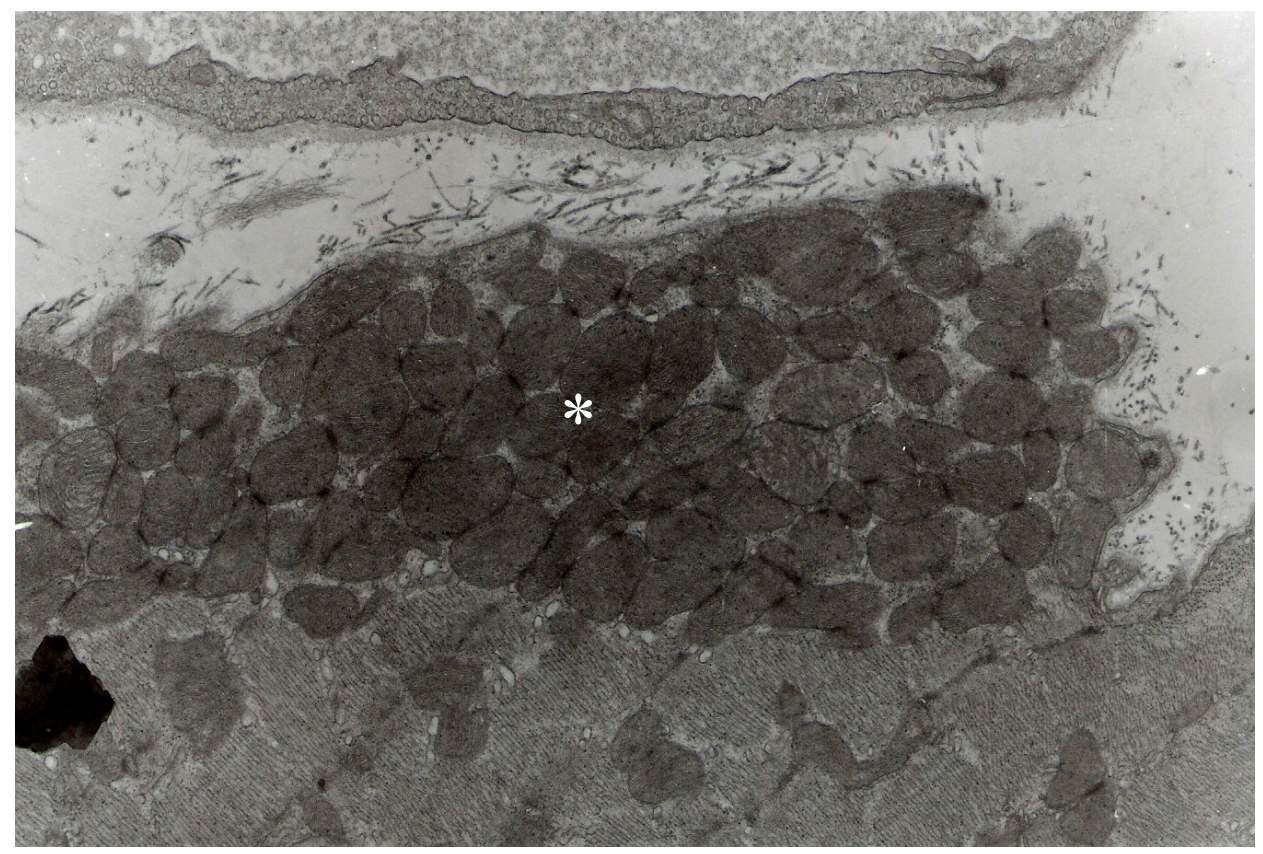

Figura 26. Microscopia eletrônica de transmissão. Peça fixada em solução de Karnovsky modificada, pós-fixada em tetróxido de ósmio e incluída em resina Spurr. Mostra a concentração de mitocôndrias ( ${ }^{*}$ ) próximas à lâmina basal, na periferia da célula. 7.500X. 
As cristas mitocondriais compostas por dupla membrana são evidenciadas e lateralmente notam-se os feixes de miofibrilas (Fig. 27).

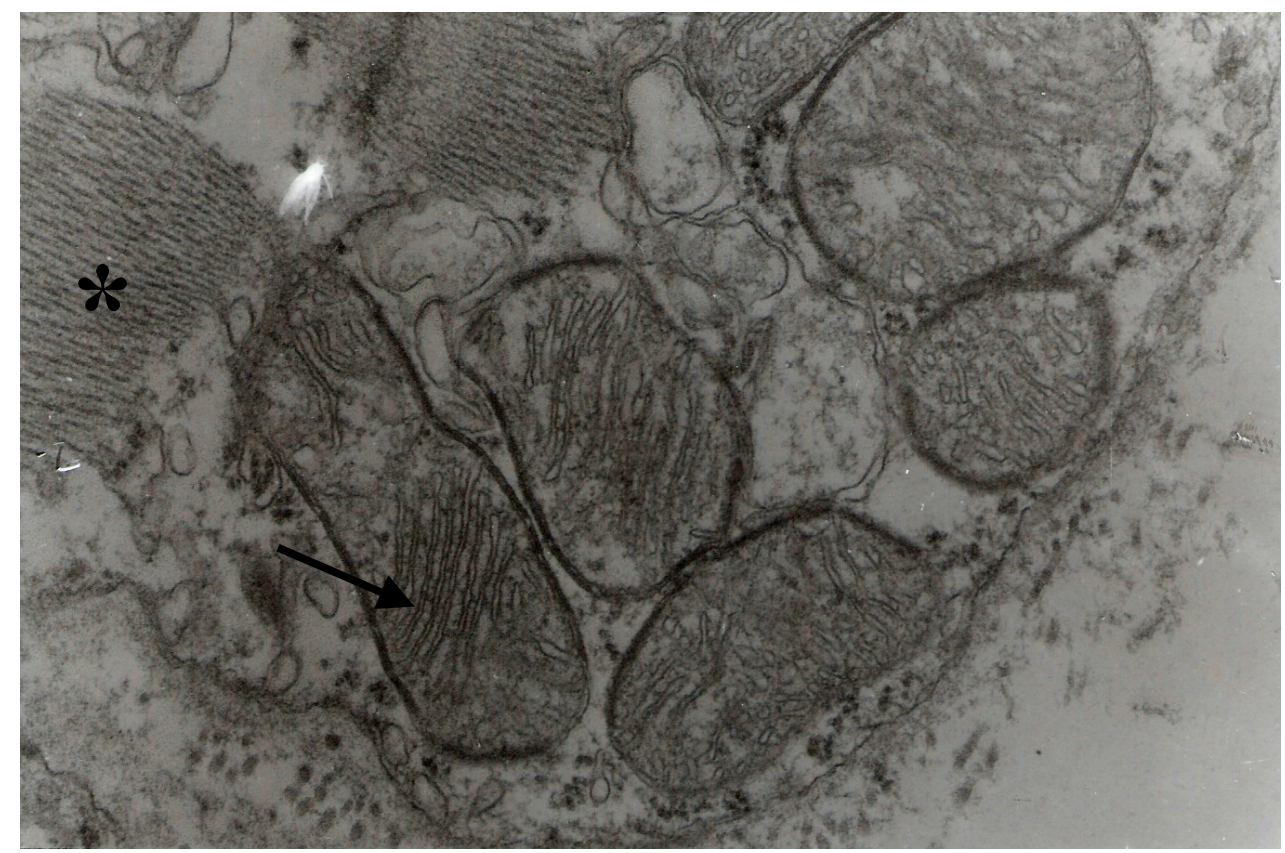

Figura 27. Microscopia eletrônica de transmissão. Revela as mitocôndrias e suas cristas compostas por dupla membrana (seta) e os feixes de miofibrilas $\left({ }^{*}\right)$. 25.000X.

O núcleo está localizado na porção periférica e externamente verifica-se a presença de feixes de fibras colágenas (Fig. 28). Notam-se os feixes de miofibrilas (Fig. 29) e em maior aumento os feixes entremeados de mitocôndrias (Fig. 30). 


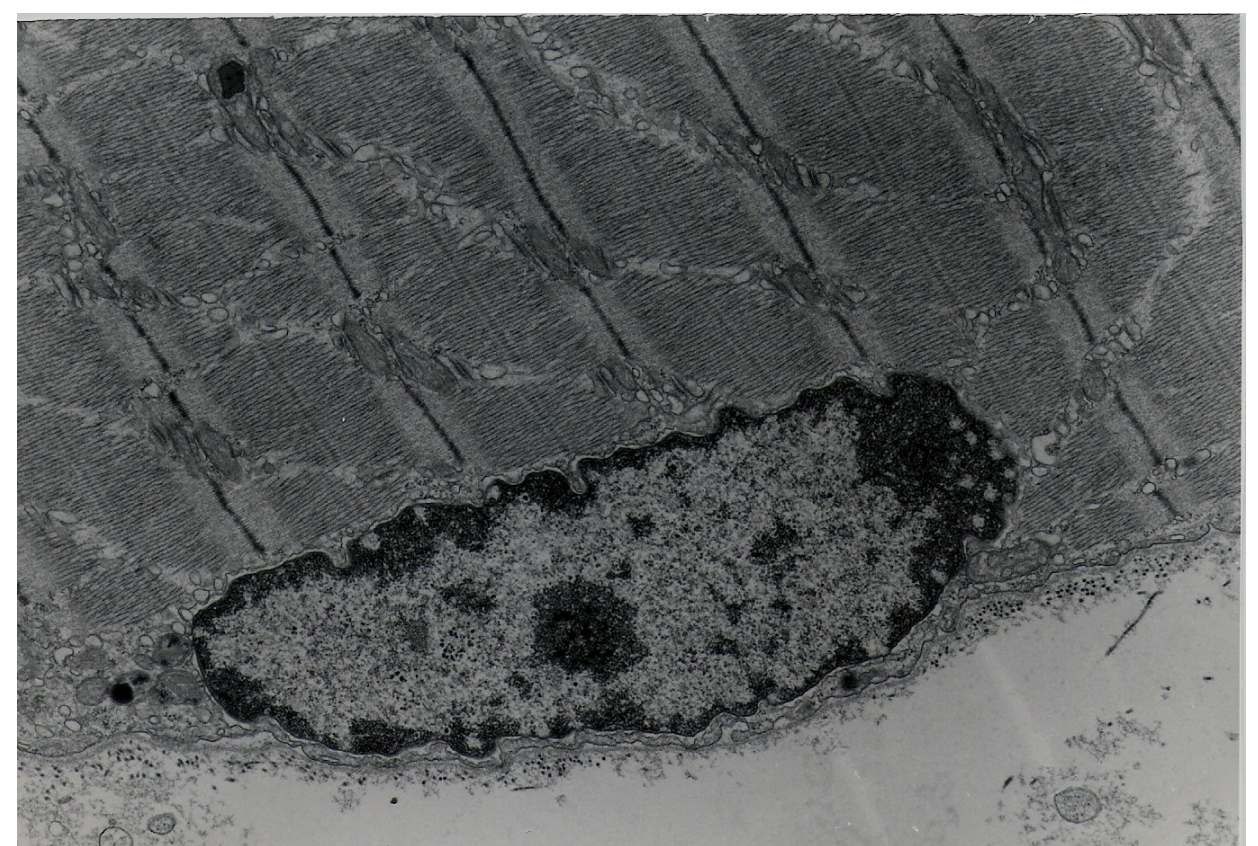

Figura 28. Microscopia eletrônica de transmissão. Peça fixada em solução de Karnovsky modificada, pós-fixada em tetróxido de ósmio e incluída em resina Spurr. Revela o núcleo na porção periférica e feixes de fibras colágenas. Notam-se as miofibrilas entremeadas de mitocôndrias e a disposição de tríades próximas à linha Z e banda I. 15.000X.

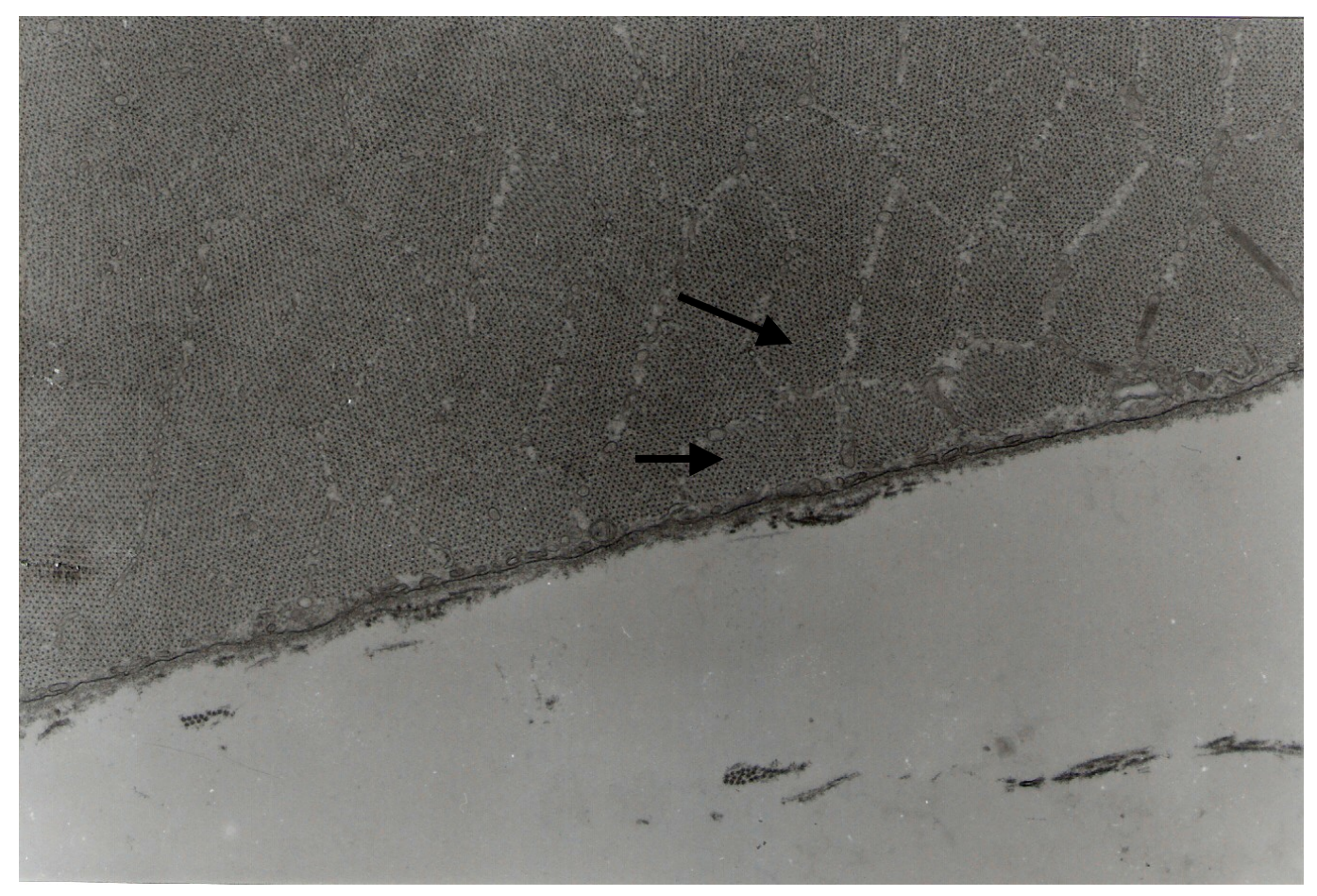

Figura 29. Microscopia eletrônica de transmissão. Observa-se a presença dos feixes de miofibrilas do músculo pterigóideo medial (setas). 10.000X. 


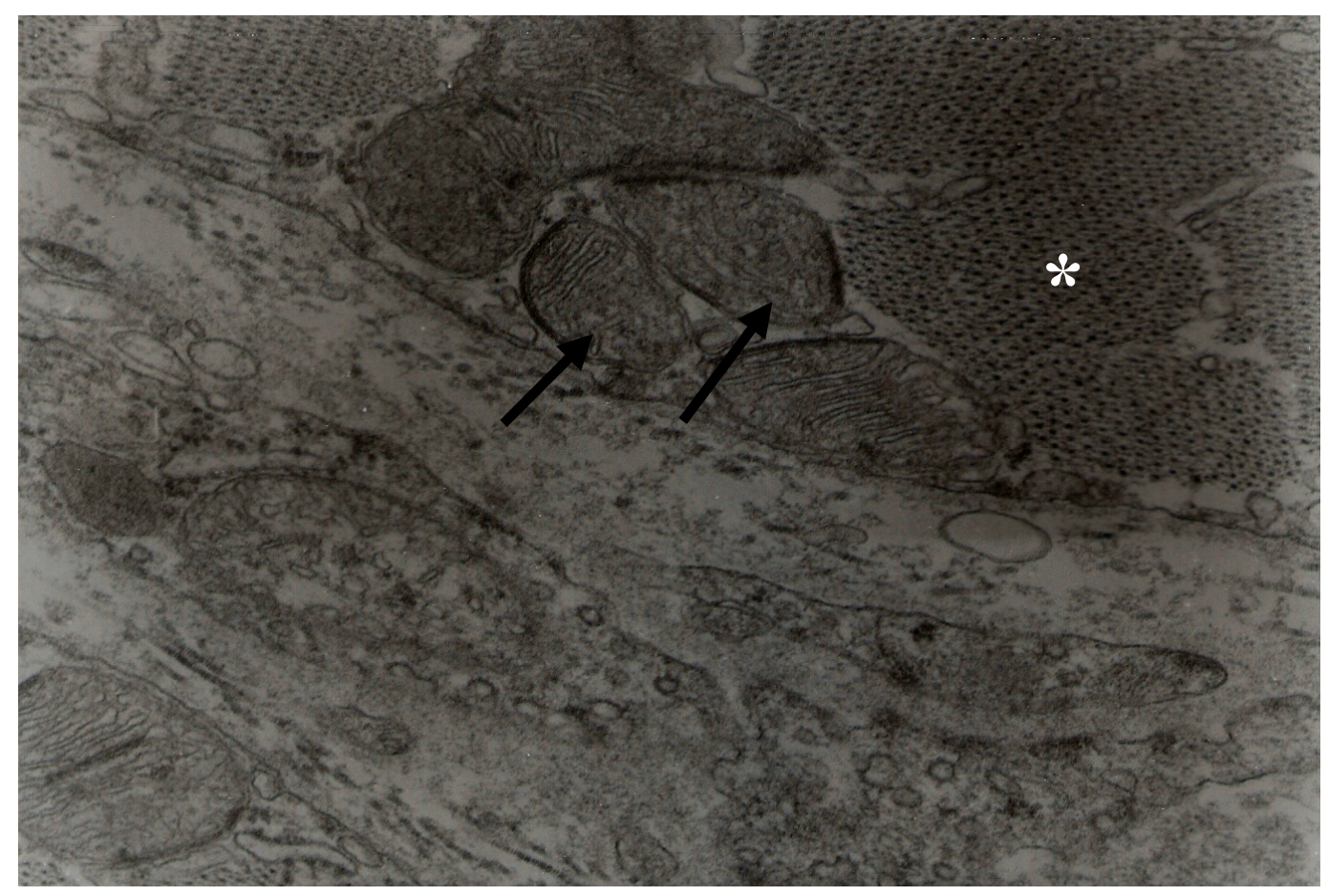

Figura 30. Microscopia eletrônica de transmissão. Peça fixada em solução de Karnovsky modificada, pós-fixada em tetróxido de ósmio e incluída em resina Spurr. Em maior aumento, notam-se mitocôndrias (setas) entremeando os feixes de miofibrilas $\left(^{*}\right)$. 25.000X.

A figura 31 mostra o núcleo da fibra muscular e os sarcômeros. Em maior aumento, as mitocôndrias de forma circular, as tríades e a disposição dos sarcômeros, são evidenciadas com as bandas I, bandas A, linha Z e linha H (Fig. 32). As mitocôndrias dispostas no interior do sarcoplasma apresentam-se geralmente localizadas na altura das semi-bandas I e aos pares (Fig. 33). Também, podem-se observar, em maior aumento, as mitocôndrias de forma circular e ovaladas, com as tríades e a disposição dos sarcômeros, evidenciando as bandas I, bandas A, linha Z e linha H (Fig. 33). 


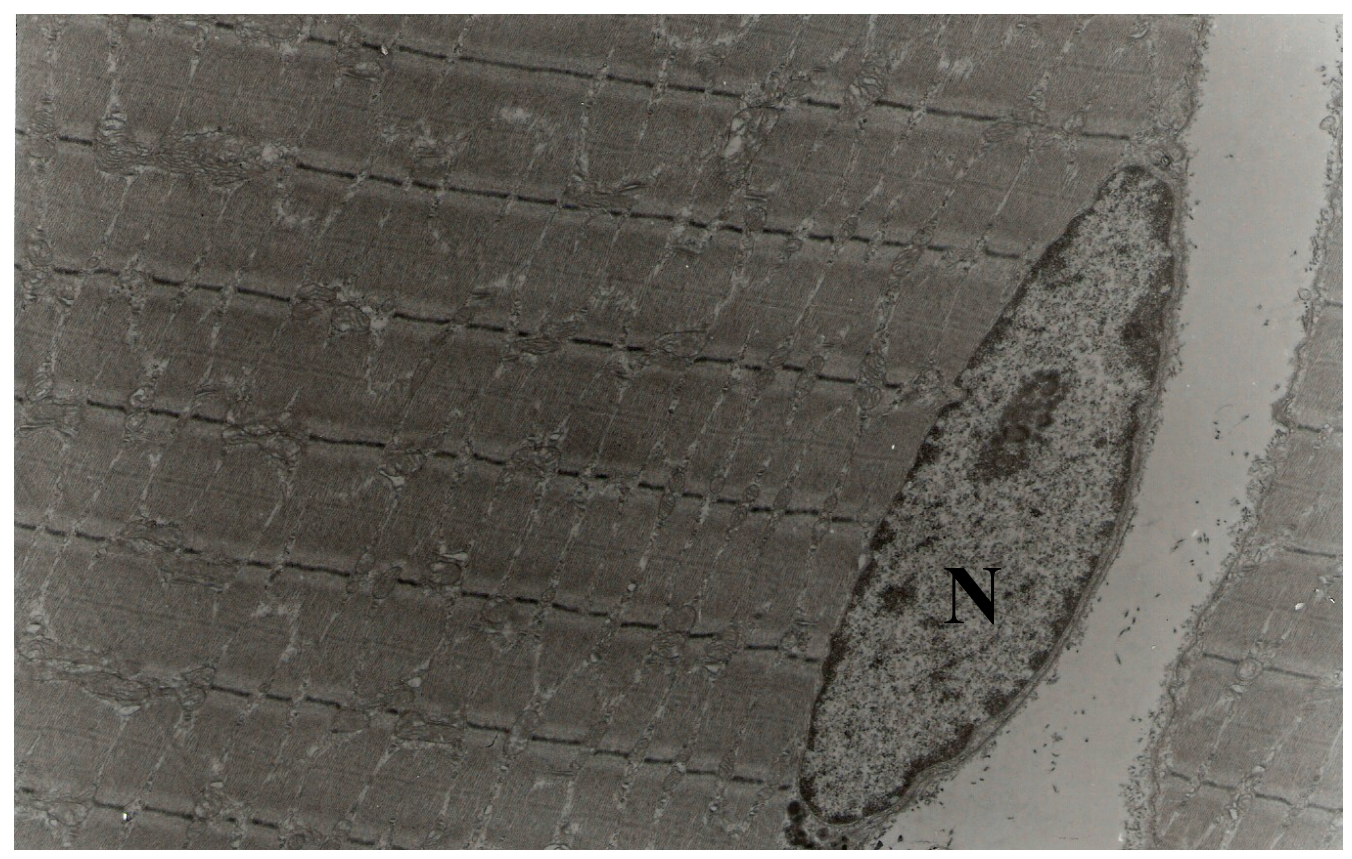

Figura 31. Microscopia eletrônica de transmissão. Peça fixada em solução de Karnovsky modificada, pós-fixada em tetróxido de ósmio e incluída em resina Spurr. Mostra o núcleo na porção periférica do citoplasma $(\mathrm{N})$ e os sarcômeros, evidenciando as bandas I, Z e A. As mitocôndrias aparecem entre os feixes de miofibrilas. 4.000X.

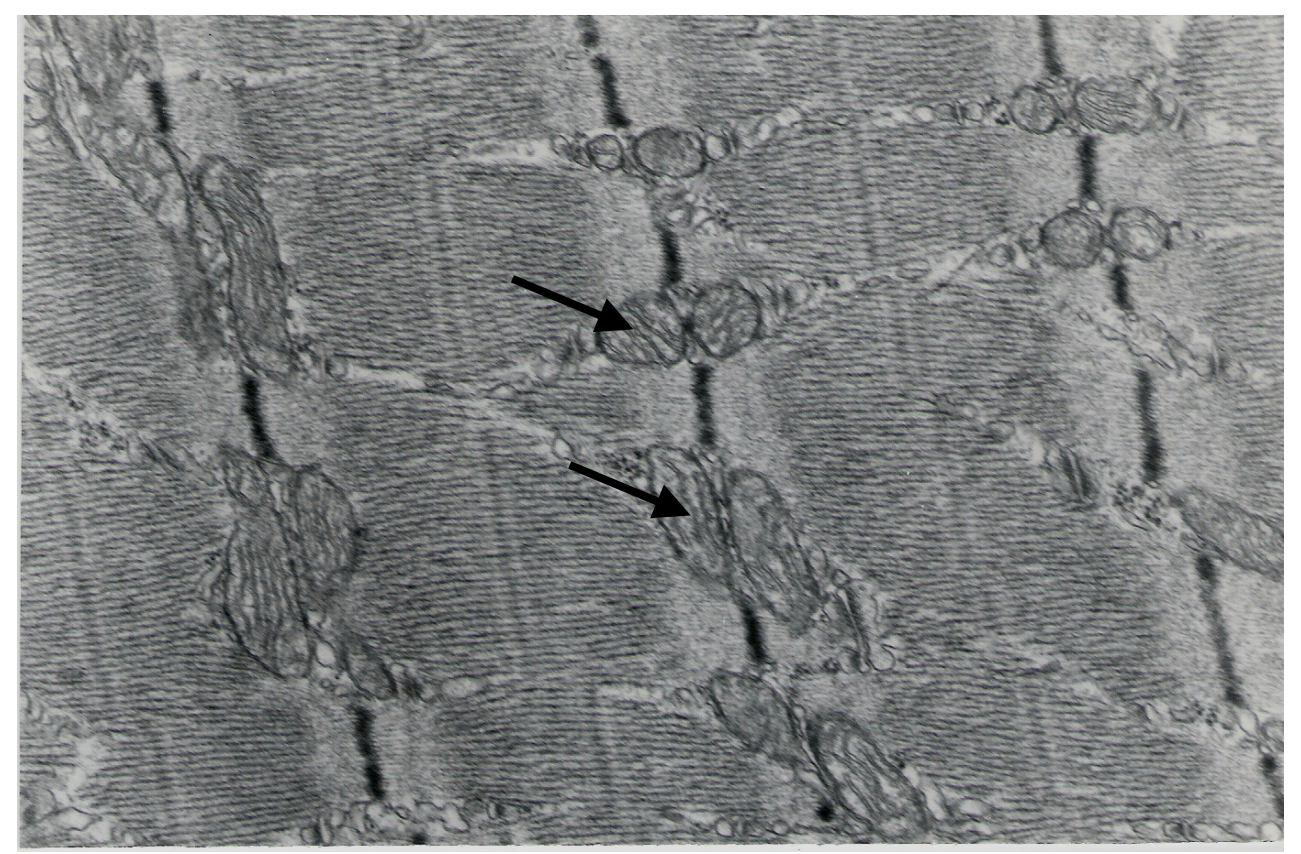

Figura 32. Microscopia eletrônica de transmissão. Mostra, em maior aumento, mitocôndrias de formas circulares e ovaladas (setas), as tríades e a disposição dos sarcômeros, evidenciando as bandas I, bandas A, linha Z e linha H. 30.000X. 


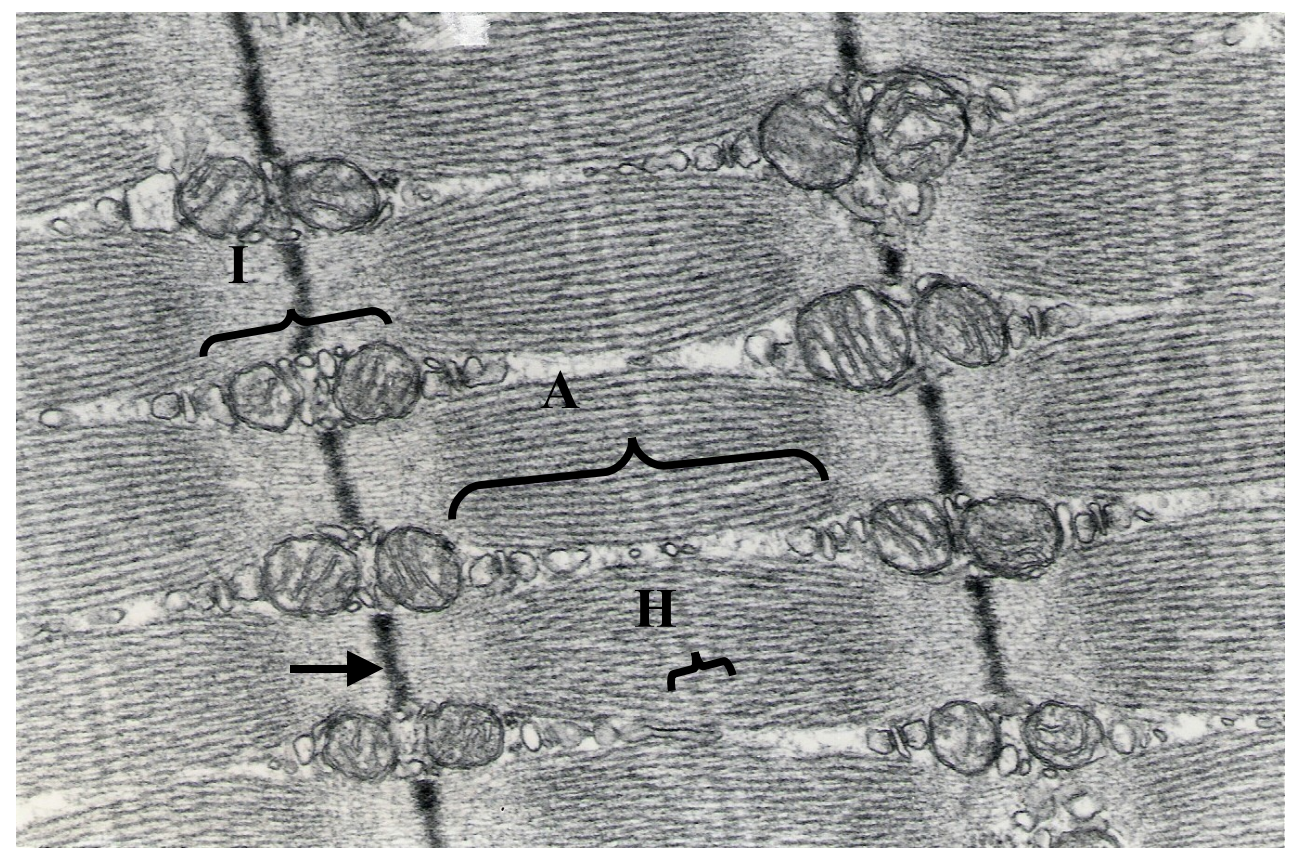

Figura 33. Mostra, em maior aumento, a fibra muscular, evidenciando mitocôndrias intercaladas entre as miofibrilas, tríades e os sarcômeros que se estendem de uma linha $Z$ (seta) a outra linha $Z$, localizadas como uma área densa na banda I (I). Nota-se também a banda $A(A)$ intercalada pela linha $H(H)$. 40.000X.

Ao microscópio eletrônico de transmissão foram observadas mitocôndrias intercaladas entre as miofibrilas, tríades e os sarcômeros que se estendem de uma linha $Z$ a outra linha $Z$, localizadas como uma área densa na banda I. Nota-se também a banda A intercalada pela linha H (Fig. 34). Identificaram-se nitidamente as mitocôndrias e feixes de miofibrilas seccionadas longitudinalmente (Fig. 34). Numa análise mais detalhada das mitocôndrias, podem-se observar cristas mitocondriais, cujas paredes opostas se interpõem paralelamente. 


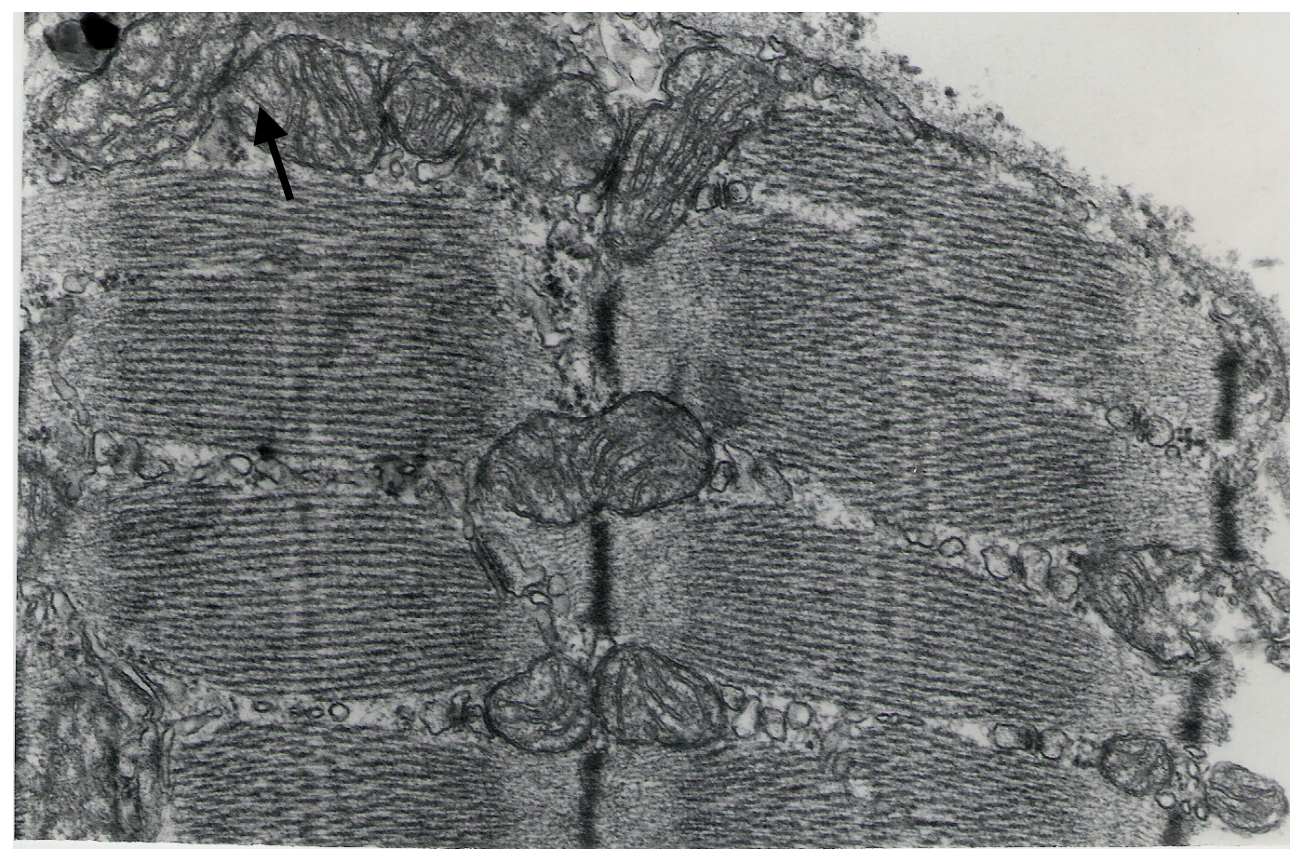

Figura 34. Microscopia eletrônica de transmissão. Observam-se nitidamente as mitocôndrias (seta), com suas cristas mitocondriais e feixes de miofibrilas dispostas longitudinalmente. 40.000X.

Nos capilares presentes próximos à inserção óssea das fibras musculares (Fig. 35), também foi possível observar grande número de cavéolas e vesículas (Fig. 36), assim como as projeções citoplasmáticas e a junções celulares (Fig. 37). 


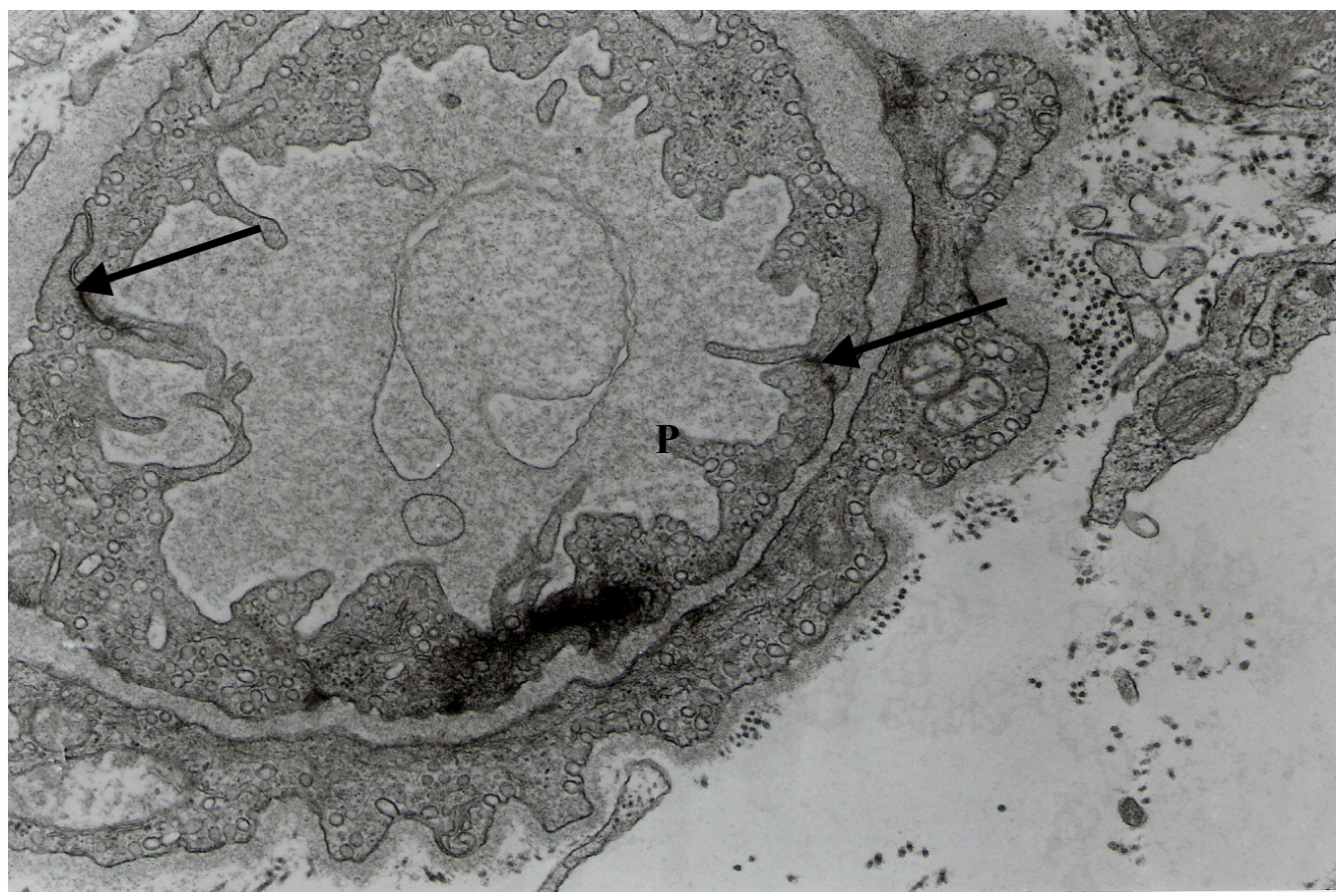

Figura 35. Microscopia eletrônica de transmissão. Peça fixada em solução de Karnovsky modificada, pós-fixada em tetróxido de ósmio e incluída em resina Spurr. Aspecto geral de um capilar. Evidencia as células endoteliais, revelando as projeções citoplasmáticas $(P)$, cavéolas e junções entre as células (setas). 12.000X.

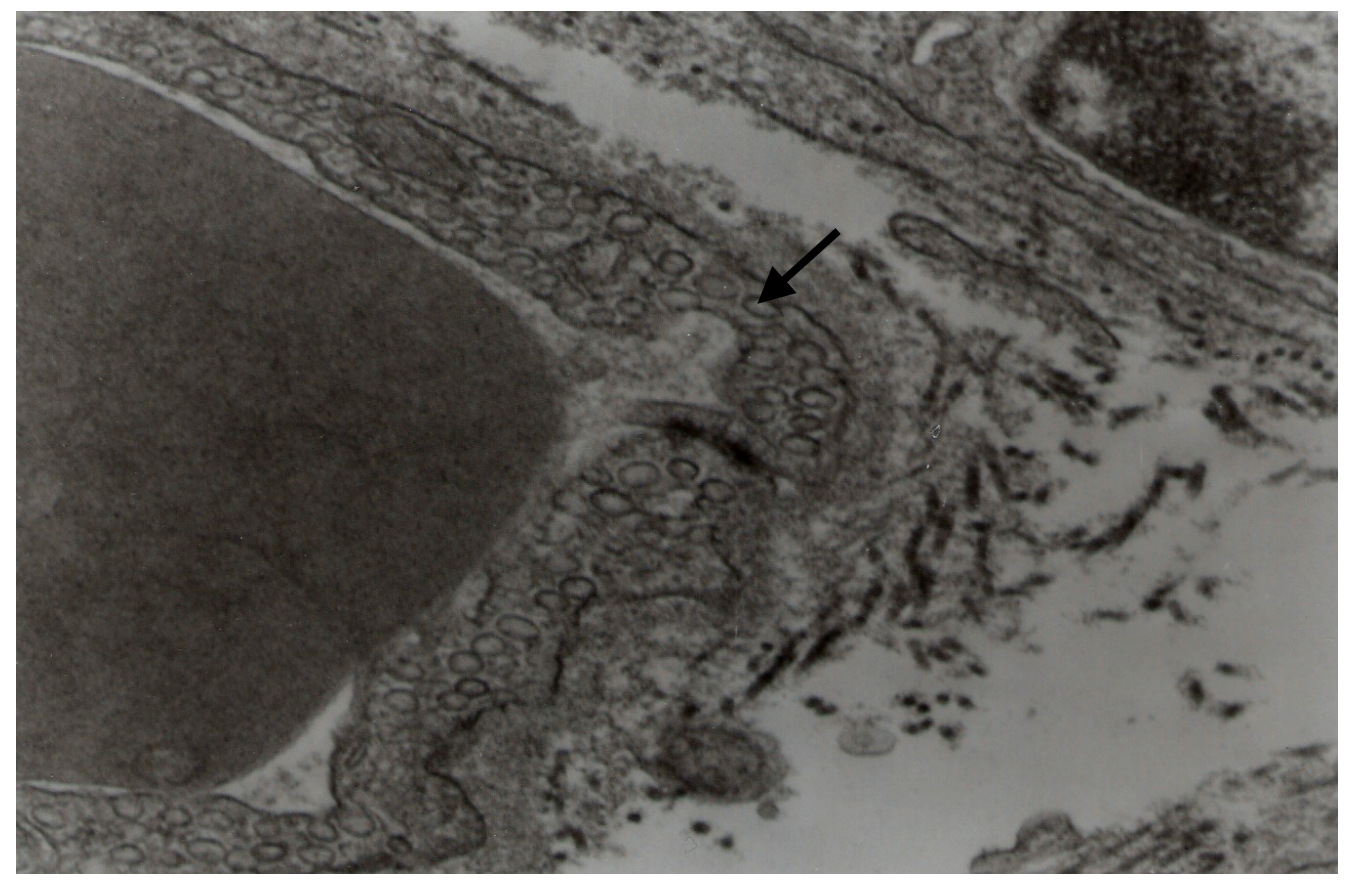

Figura 36. Microscopia eletrônica de transmissão. Peça fixada em solução de Karnovsky modificada, pós-fixada em tetróxido de ósmio e incluída em resina Spurr. Evidencia um capilar e a presença de cavéolas (seta) e vesículas. 25.000X. 


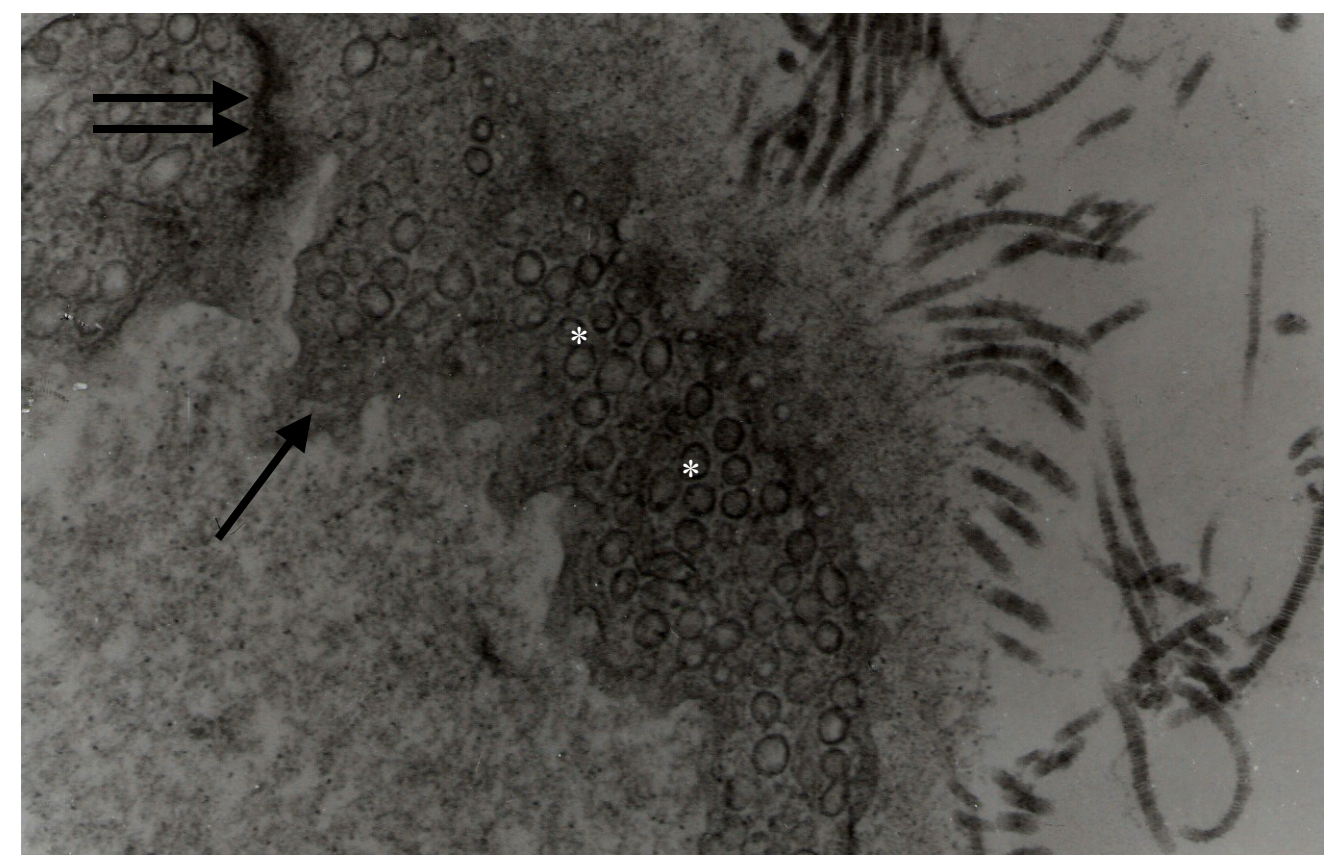

Figura 37. Microscopia eletrônica de transmissão. Peça fixada em solução de Karnovsky modificada, pós-fixada em tetróxido de ósmio e incluída em resina Spurr. Mostra as junções entre as células endoteliais do capilar sangüíneo (duas setas), as projeções citoplasmáticas (seta) e as vesículas pinocíticas $\left(^{*}\right)$. 30.000X.

Ao observarmos a região da junção miotendínea do músculo pterigóideo medial notamos que as miofibrilas emitem projeções que se interdigitam às fibras colágenas, aumentando assim a superfície de contato entre estas estruturas. (Fig. $38,39,40$ e 41). 


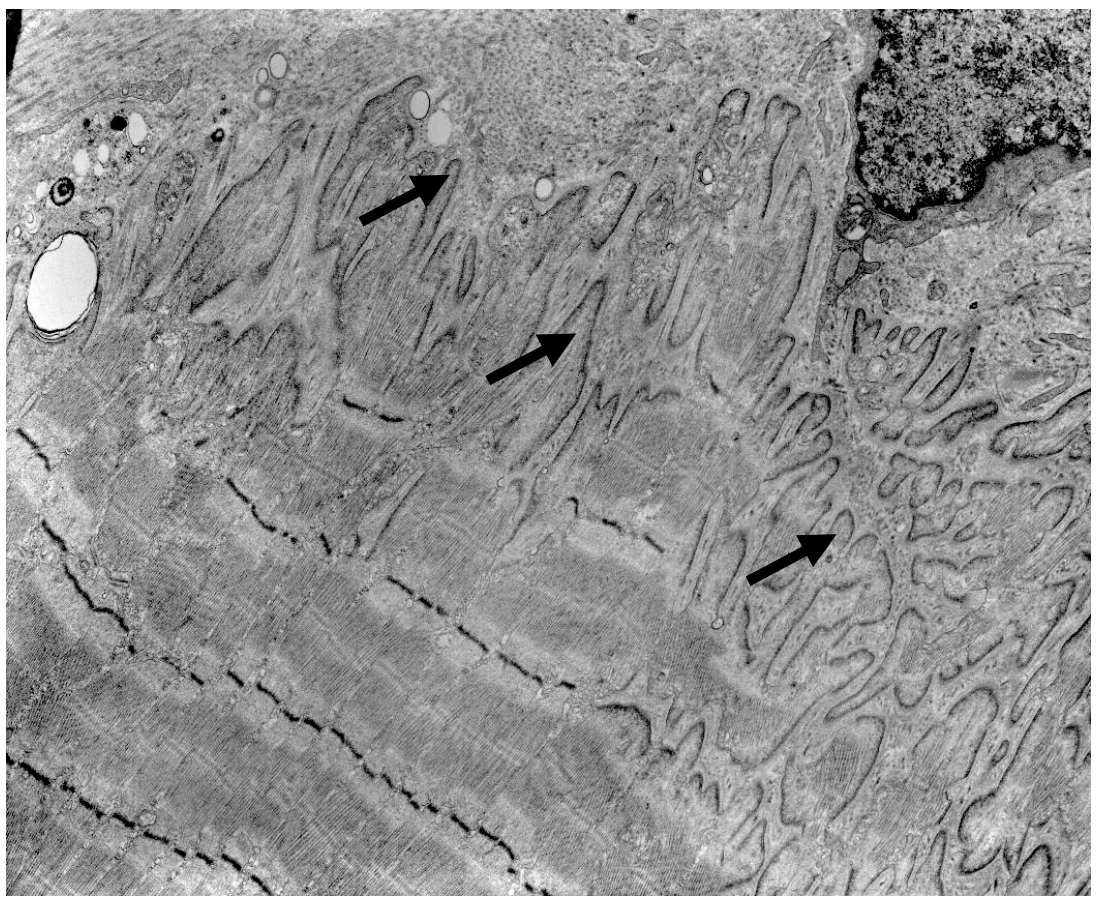

Figura 38. Microscopia eletrônica de transmissão. Observa-se a região da junção miotendínea do músculo pterigóideo medial. Notam-se numerosas projeções sarcoplasmáticas (setas). 7.500X.

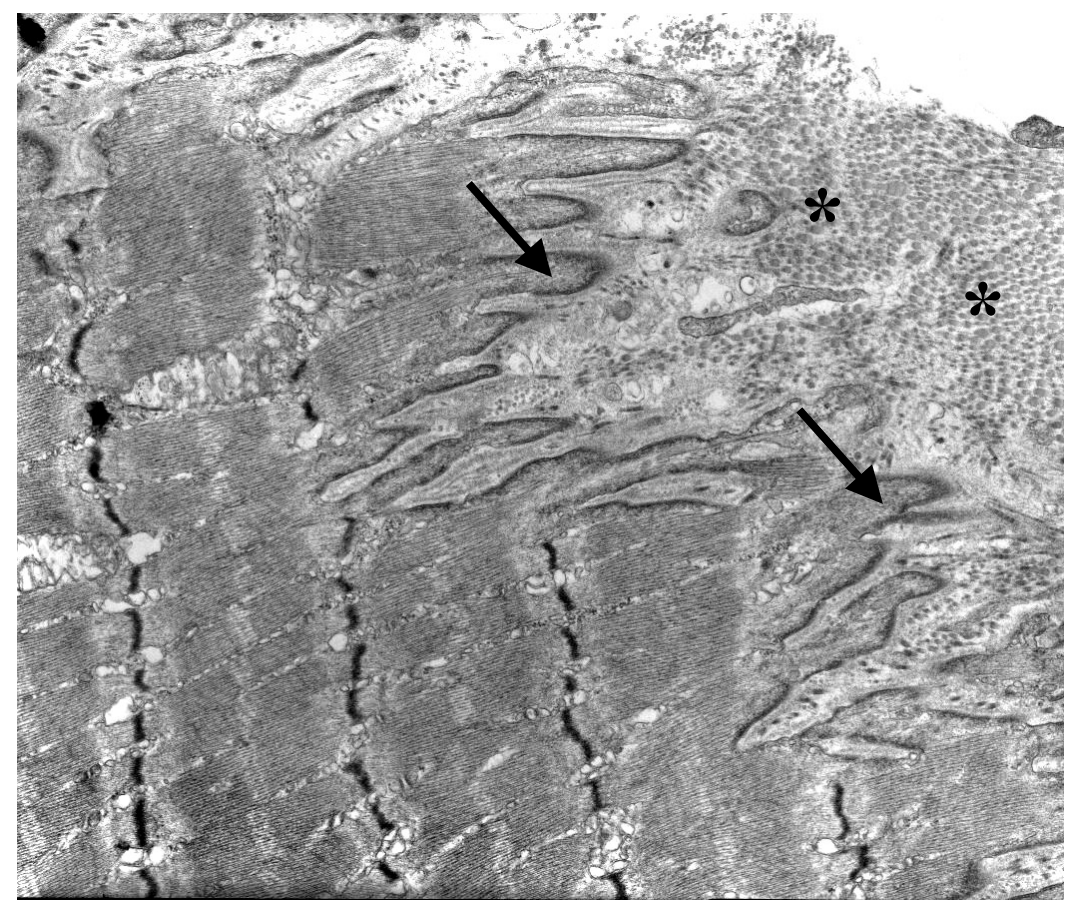

Figura 39. Microscopia eletrônica de transmissão. Notam-se as invaginações dos feixes de miofibrilas (setas) e o tecido colágeno $\left(^{*}\right)$ na região da junção miotendínea. $10.000 \mathrm{X}$. 


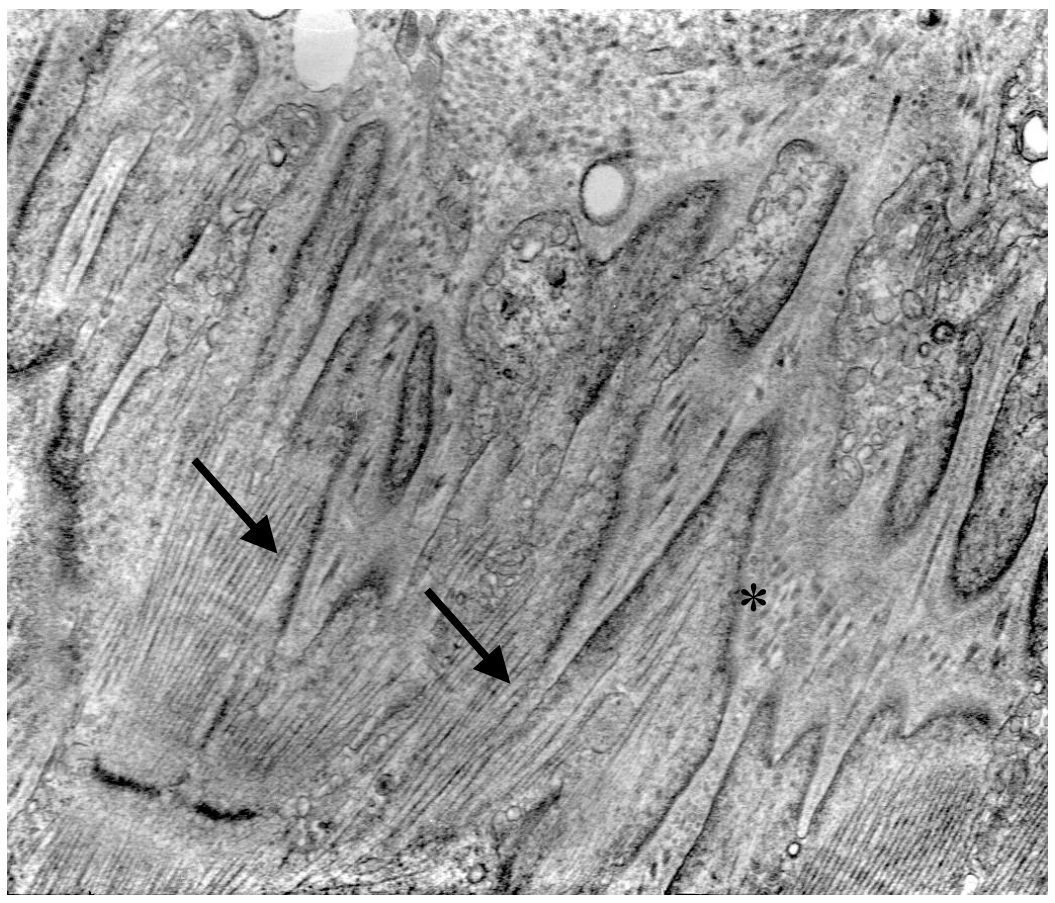

Figura 40. Microscopia eletrônica de transmissão. Notam-se as projeções sarcoplasmáticas contendo os miofilamentos (setas) e a presença de fibras colágenas que se ligam à membrana sarcoplasmática $\left(^{*}\right)$. 20.000X.

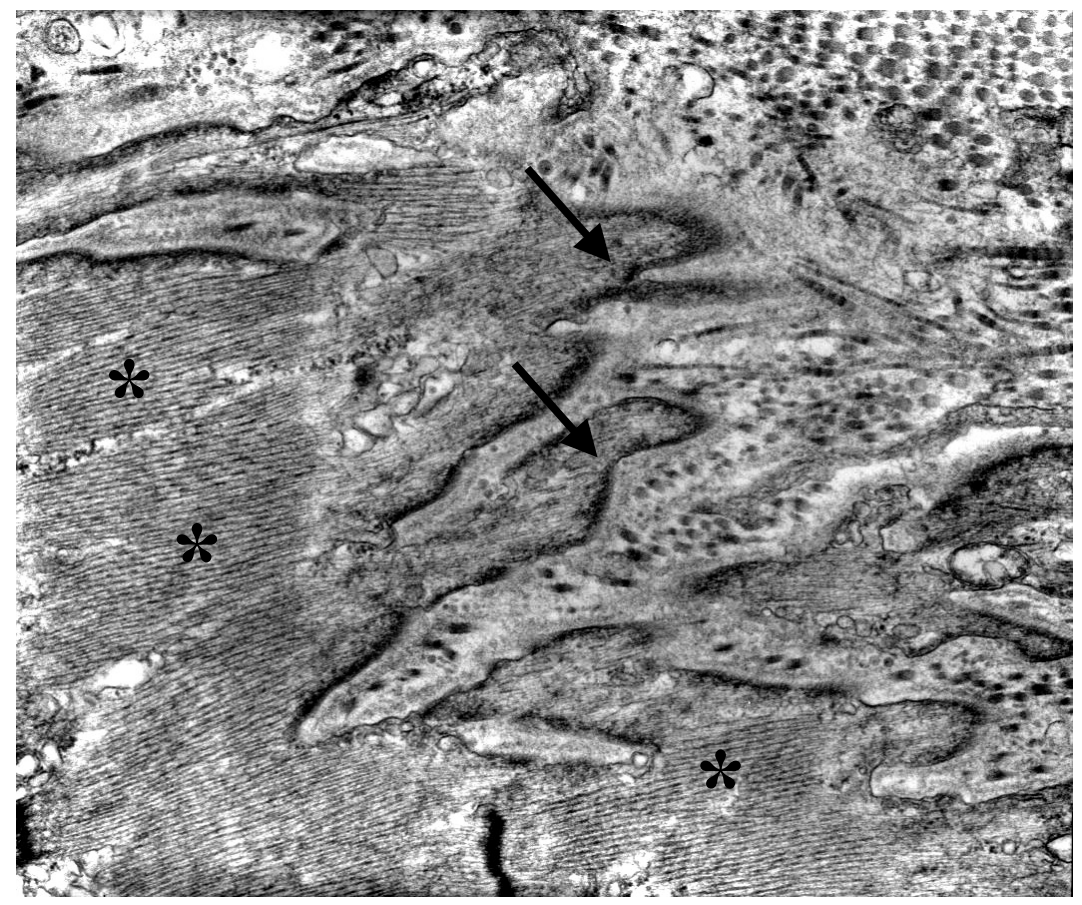

Figura 41. Microscopia eletrônica de transmissão. Evidencia as projeções em forma de dedos da junção miotendínea (setas) e a presença de miofibrilas $\left({ }^{*}\right)$. 20.000X.

Os feixes de fibras colágenas que constitutem o endomísio podem ser notados dispostos longitudinalmente (Fig. 42). 


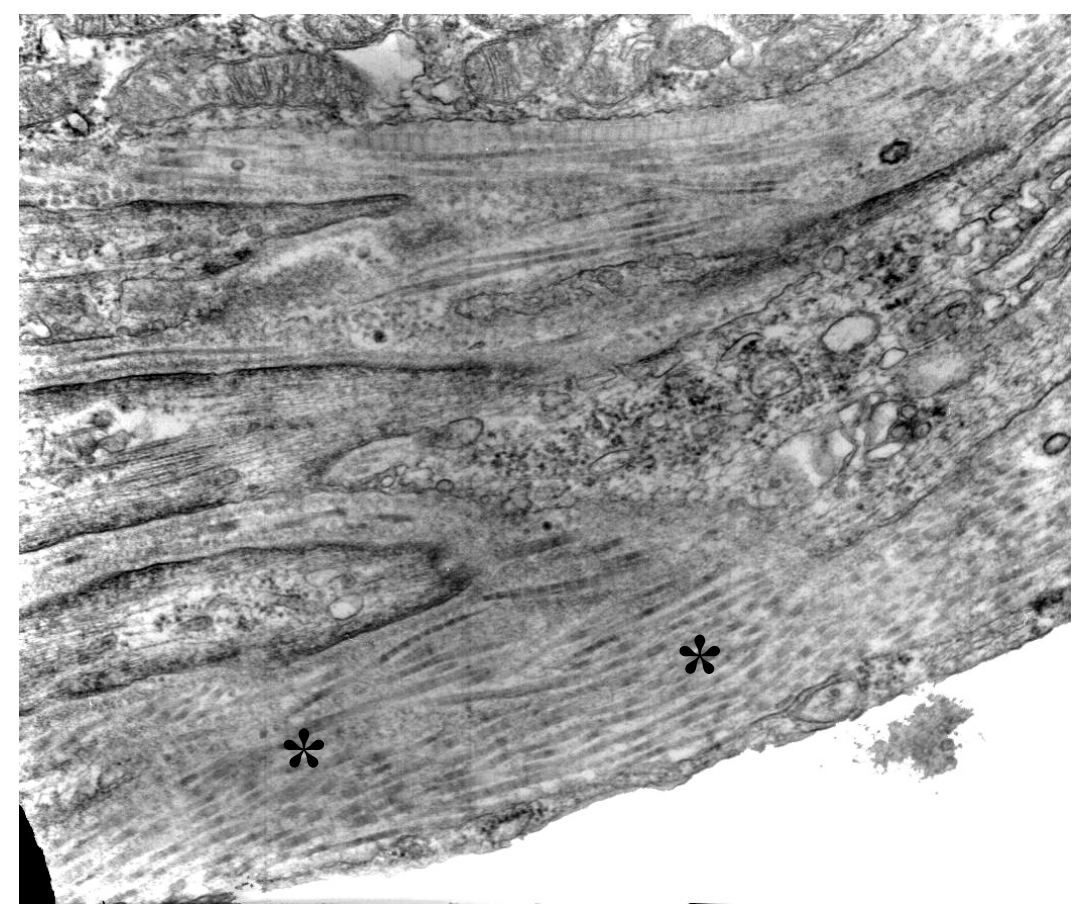

Figura 42. Microscopia eletrônica de transmissão. Em maior aumento observam-se os feixes longitudinais de fibras colágenas que compõem o endomísio $\left(^{*}\right)$. 20.000X.

\section{Rato adulto}

Nos cortes corados com solução de hematoxilina-eosina, pode-se observar a área de inserção das fibras musculares na mandíbula (Fig. 43) assim como a disposição periférica dos núcleos (Fig. 44) e a presença de fibroblastos no tecido conjuntivo aderente à superfície óssea (Fig. 45). 


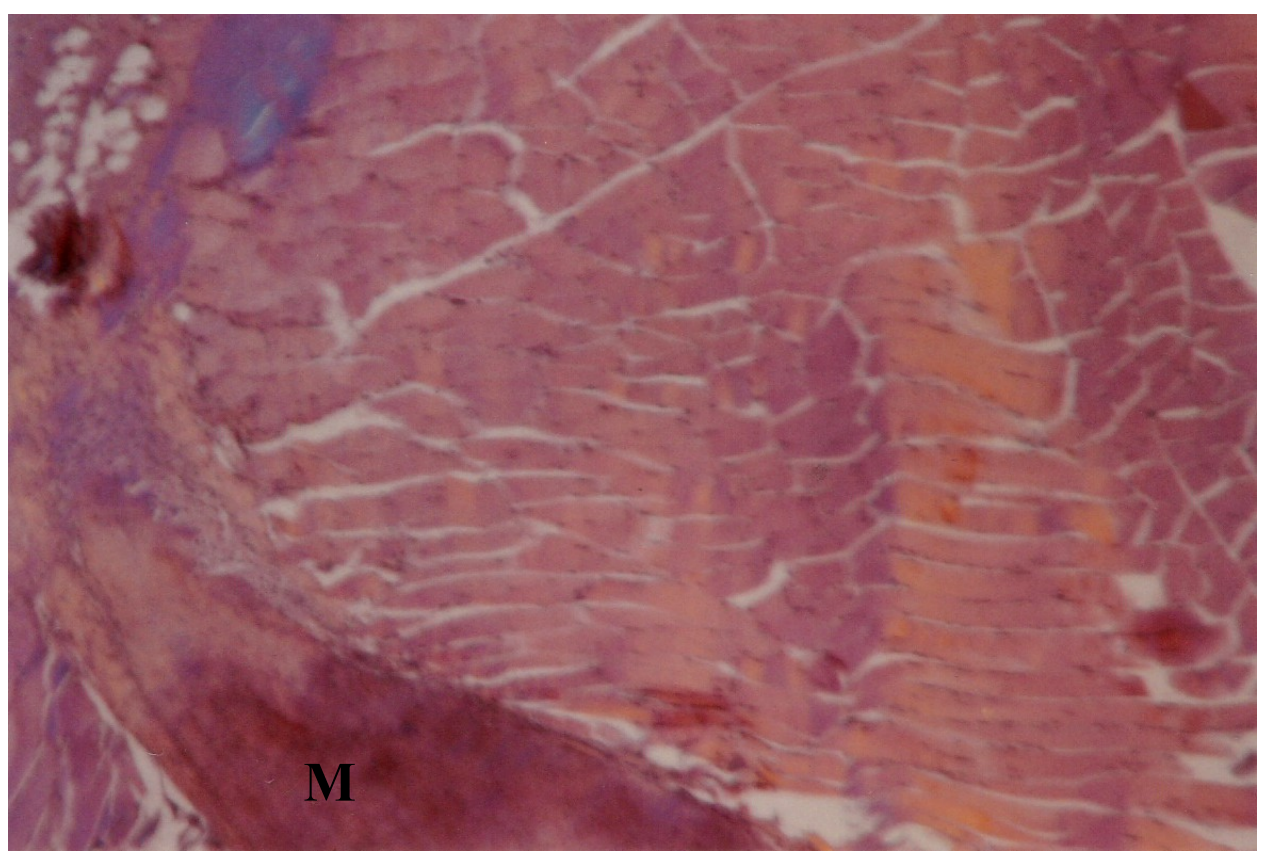

Figura 43. Microscopia de luz. Corte histológico do músculo pterigóideo medial de rato adulto. Mostra a área de inserção das fibras musculares na face medial do ângulo da mandíbula (M) em corte longitudinal. 64X. Coloração: Hematoxilina-Eosina.

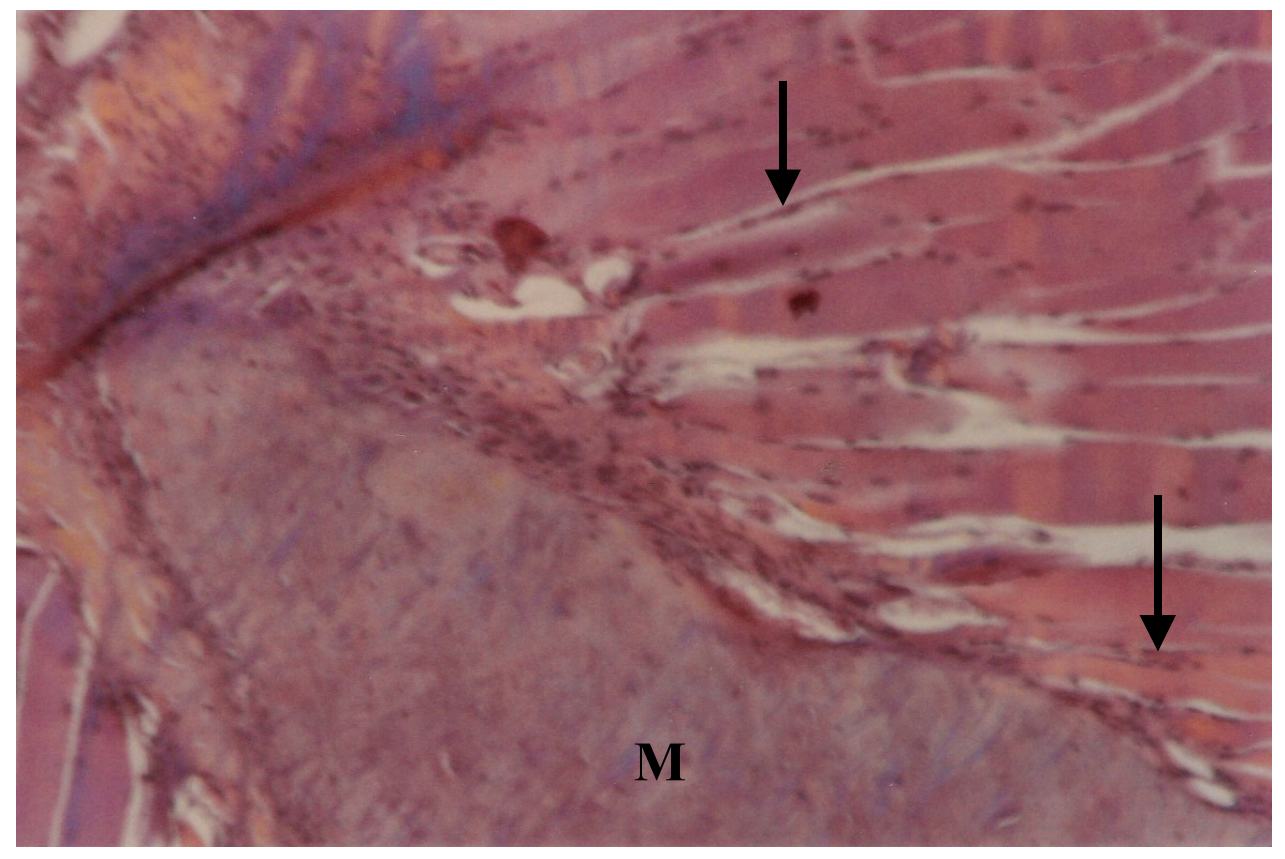

Figura 44. Microscopia de luz. Corte histológico do músculo pterigóideo medial de rato adulto. Observa-se a inserção oblíqua das fibras na mandíbula e a disposição dos núcleos (setas) das células musculares em sua porção periférica. 120X. Coloração: Hematoxilina-Eosina. 


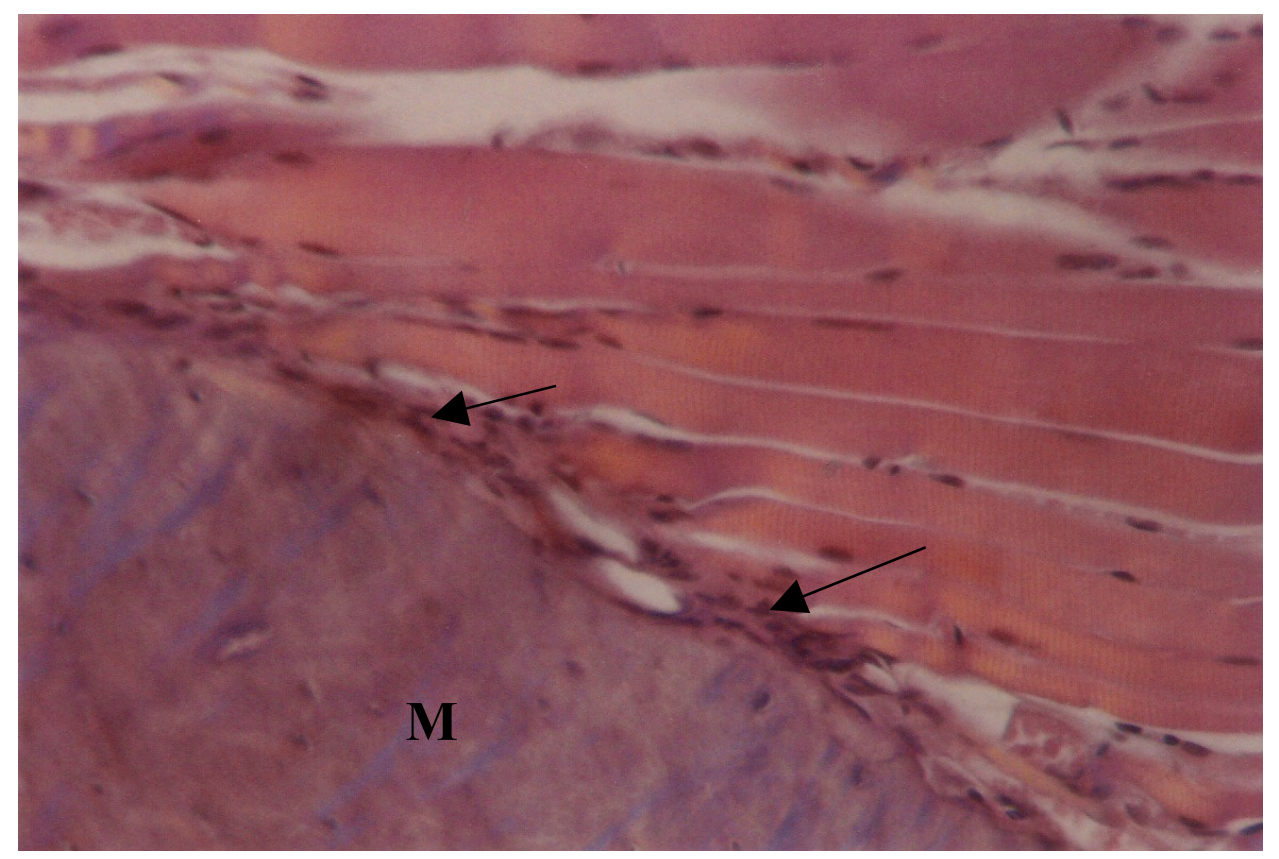

Figura 45. Microscopia de luz. Corte histológico do músculo pterigóideo medial de rato adulto. As fibras musculares aderem-se à superfície óssea (M) através do tecido conjuntivo (setas). 120X. Coloração: Hematoxilina-Eosina.

Pôde-se observar a presença dos forames nutrícios no osso mandibular (Fig. 46).

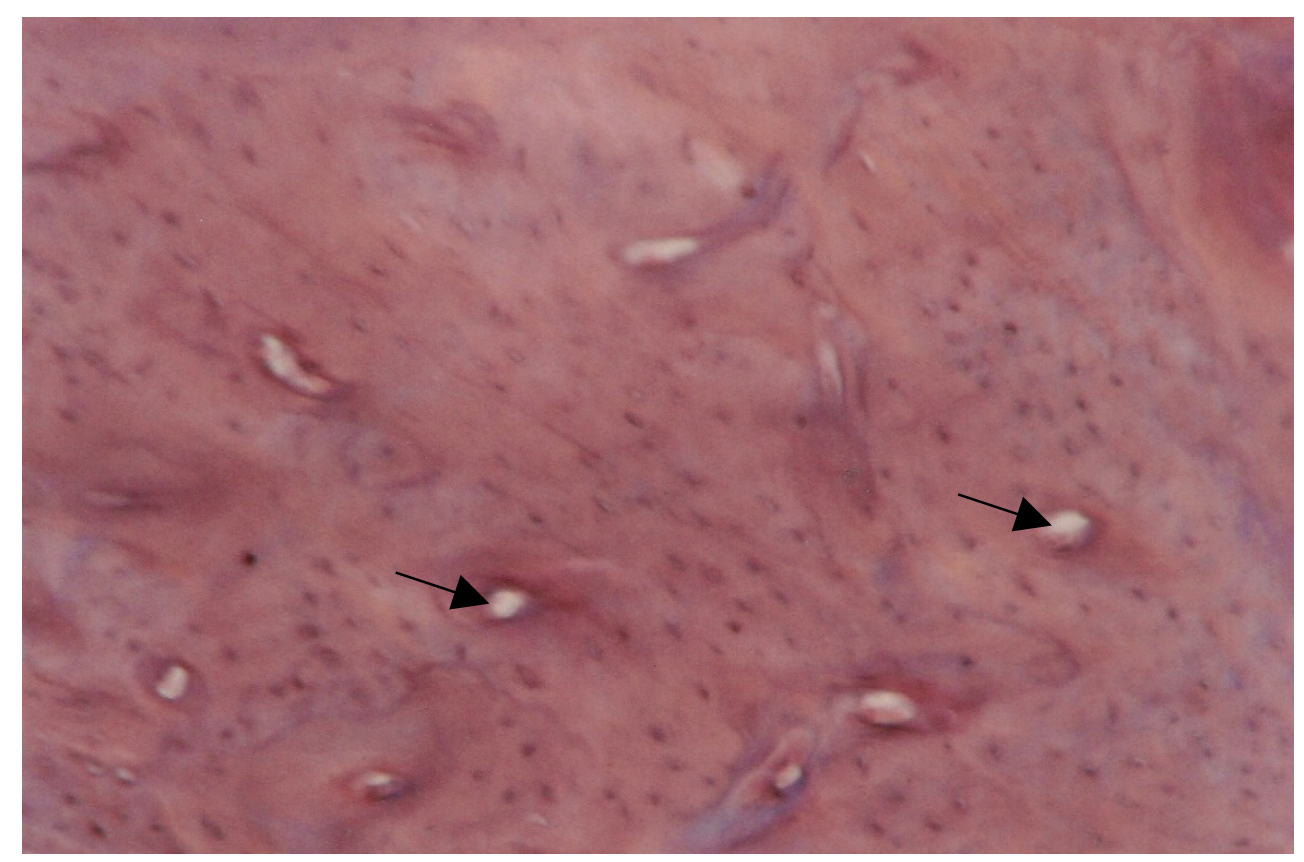

Figura 46. Microscopia de luz. Na superfície óssea podemos observar os forames nutrícios (setas). 120X. Coloração: Hematoxilina-Eosina. 
O método Azo-Carmin evidenciou na área de inserção muscular o tecido colágeno corado em azul (Fig. 47) e os numerosos vasos sangüíneos contendo hemácias (Fig. 48).

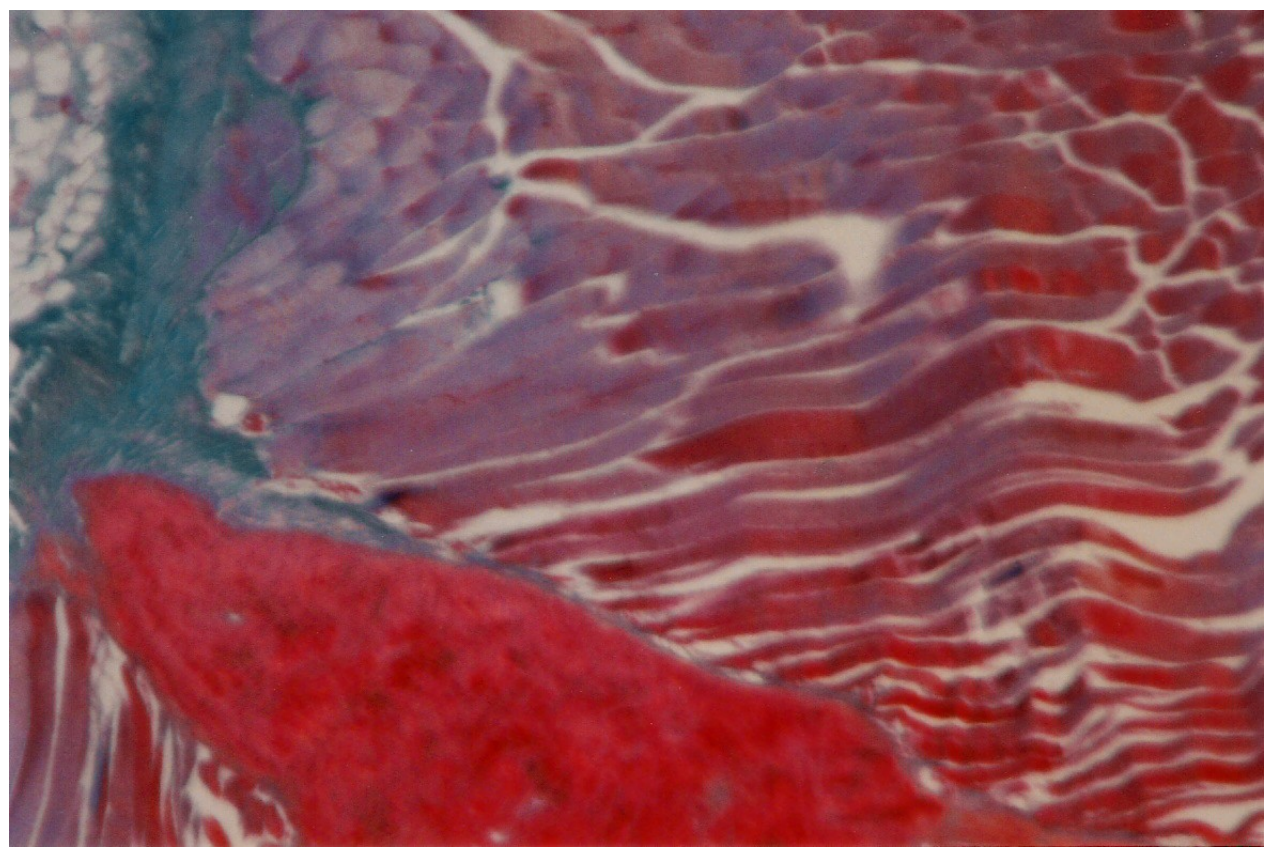

Figura 47. Corte histológico do músculo pterigóideo medial de rato adulto evidencia a inserção das fibras musculares na superfície óssea e o tecido colágeno aderido corado em azul. 120 X. Coloração: Azo-Carmin.

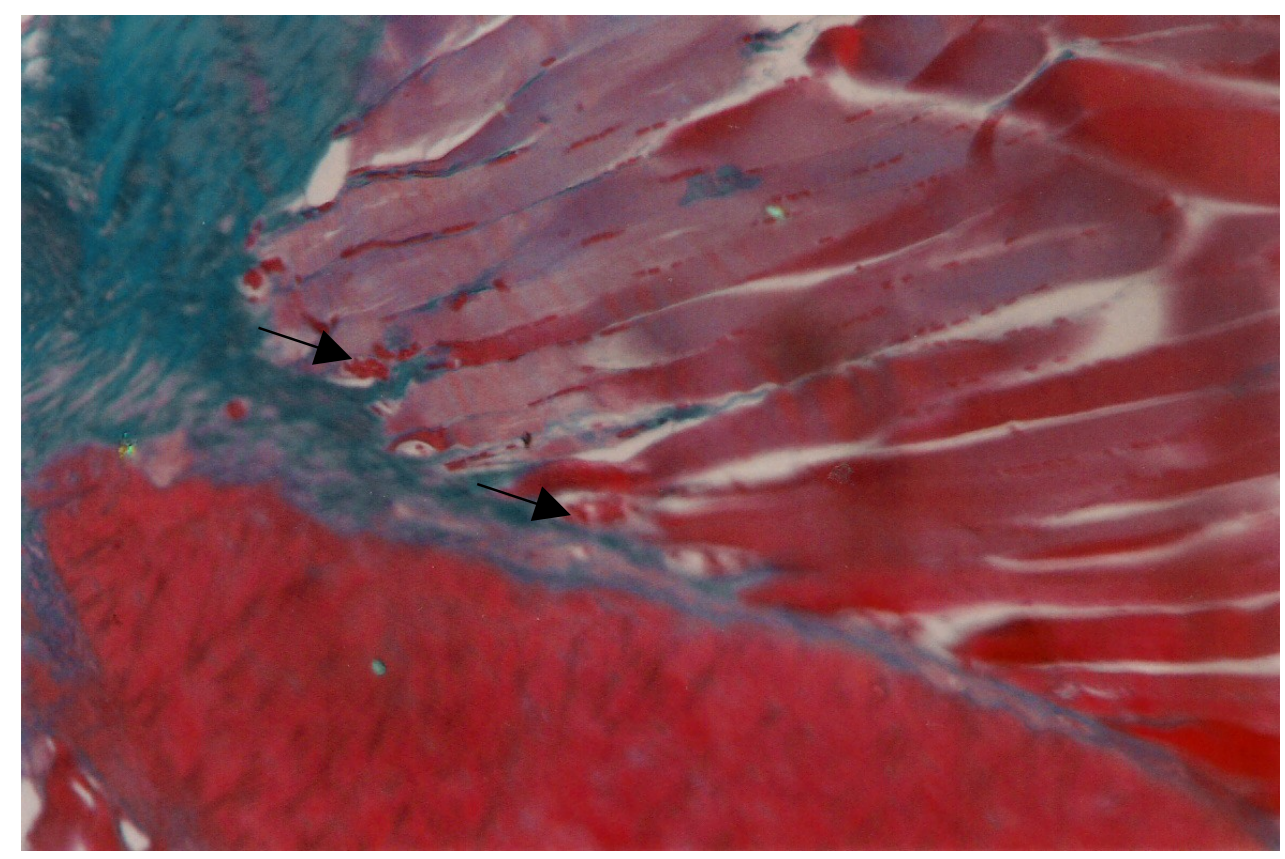

Figura 48. Microscopia de luz revela a presença de capilares (setas) contendo hemácias na região da inserção muscular. 120 X. Coloração: Azo-Carmin. 
Para a observação do endomísio, utilizou-se a coloração Picrosirius. Composto por tecido colágeno corado, em vermelho apareceu entremeando-se às fibras musculares coradas em amarelo e na área entre o músculo e a mandíbula (Fig. 49). Também apareceu em grande quantidade na superfície óssea (Fig. 50).

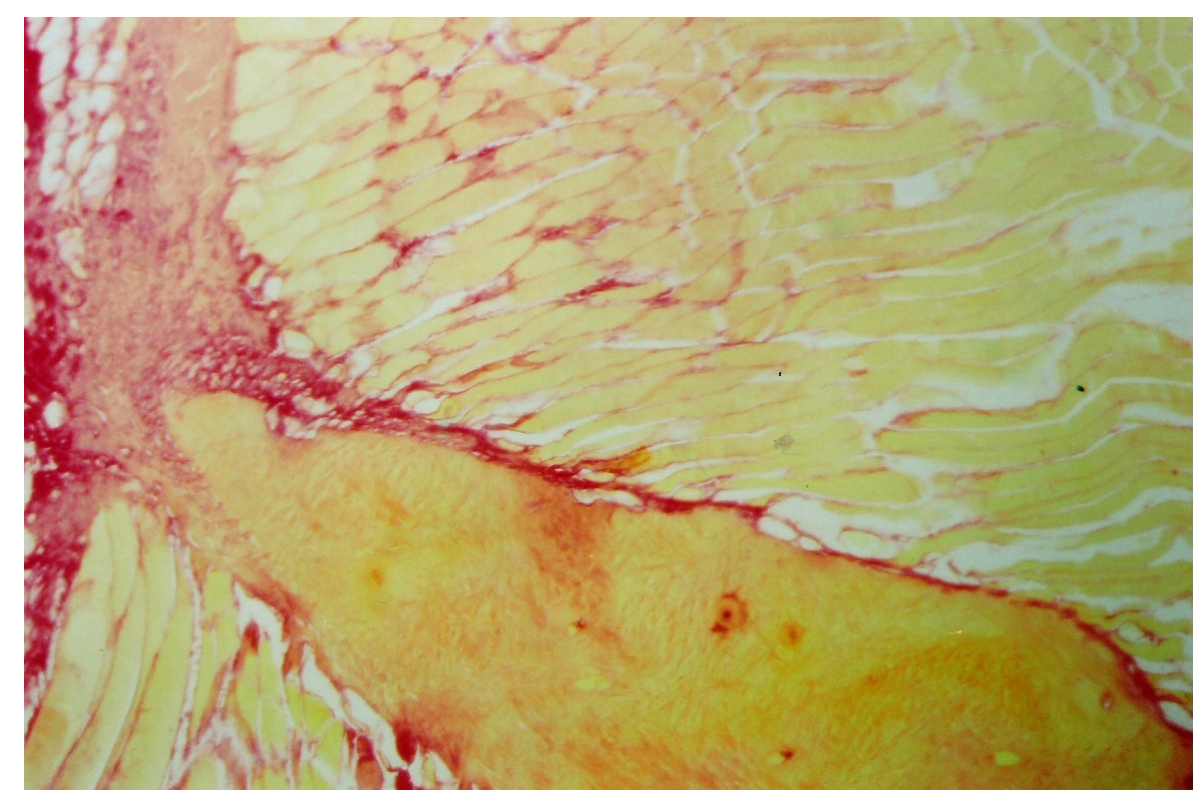

Figura 49. Microscopia de luz. Corte evidencia as fibras musculares em amarelo entremeadas por feixes de fibras colágenas coradas em vermelho. 64 X. Coloração: Picrosirius.

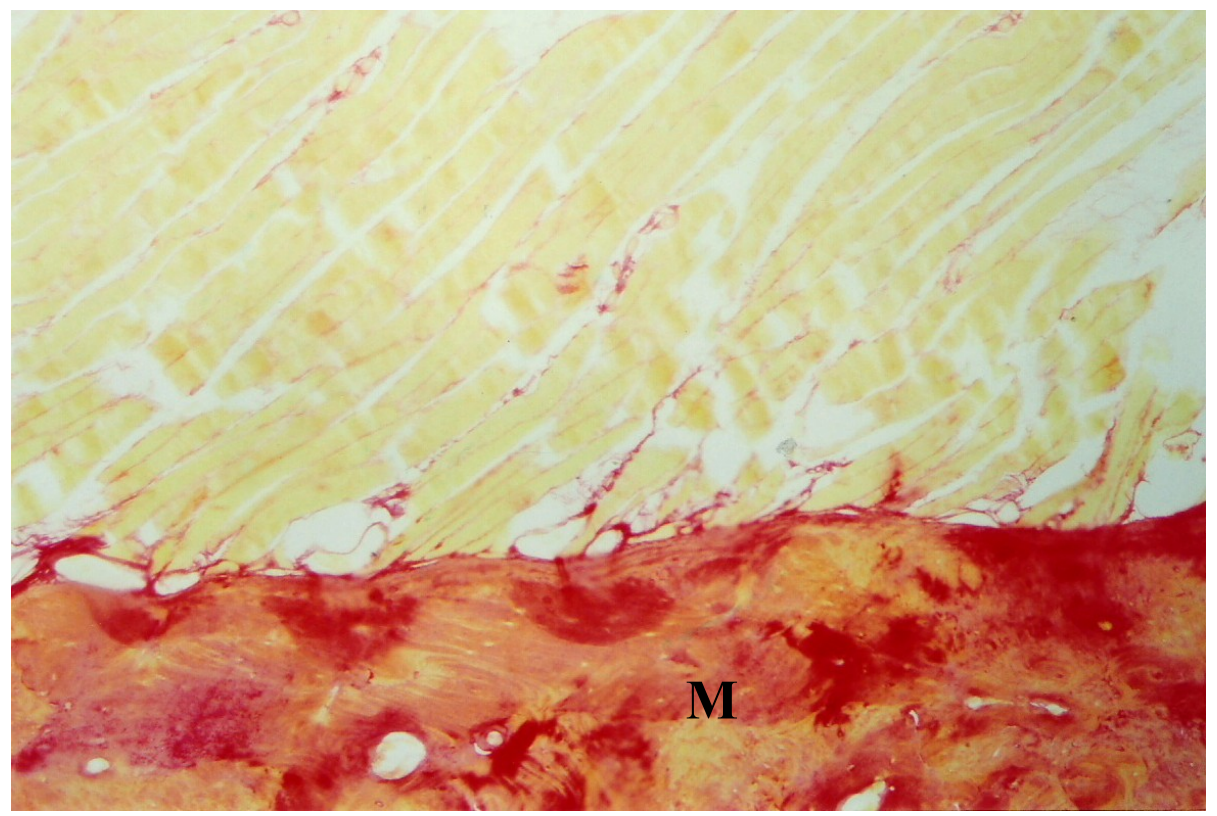

Figura 50. Microscopia de luz. Observa-se a presença do tecido colágeno corado em vermelho no osso mandibular (M). 64 X. Coloração: Picrosirius. 
Em maior aumento, pode-se notar a formação de lojas de tecido colágeno contendo cada fibra muscular (Fig. 51).

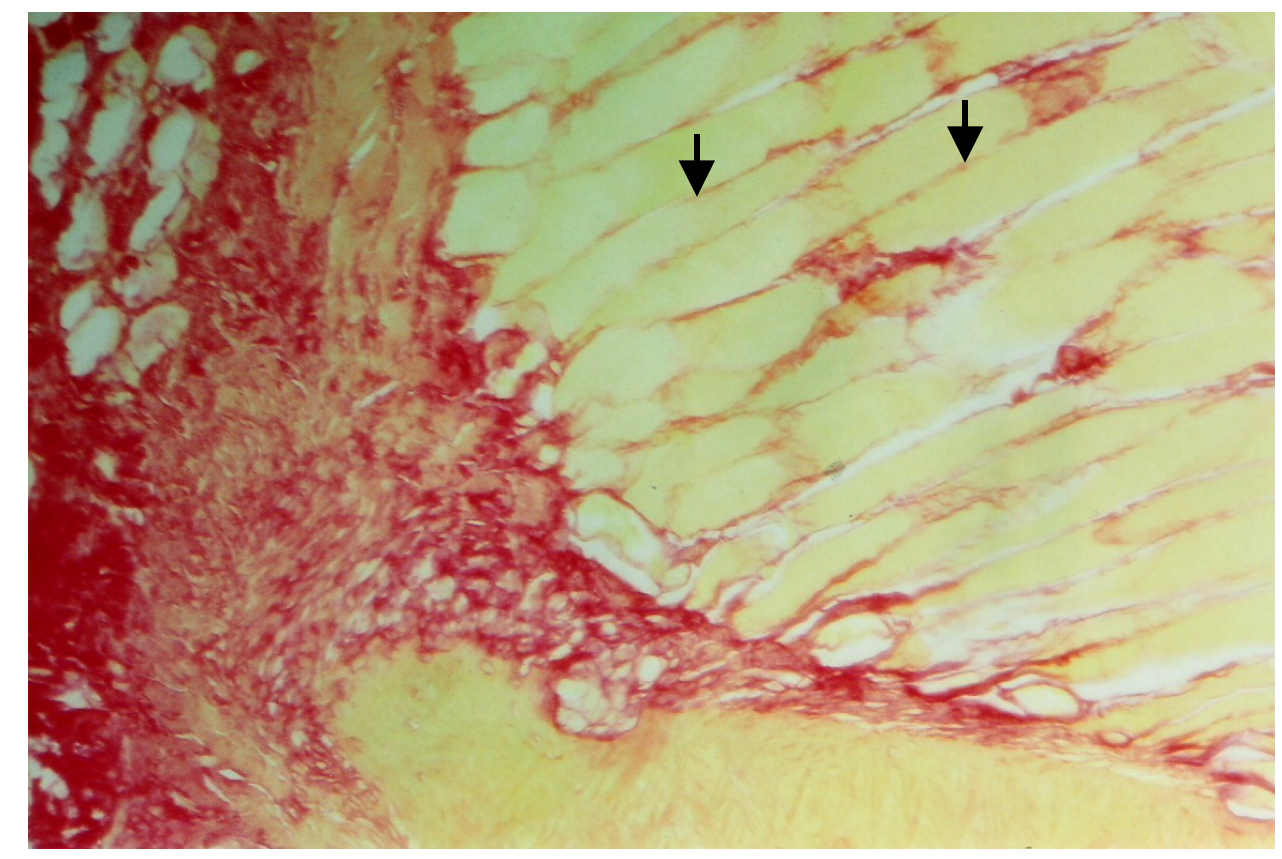

Figura 51. Microscopia de luz. Pode-se observar a presença do endomísio (setas) composto de tecido colágeno envolvendo as fibras musculares. 64 X. Coloração: Picrosirius.

O tecido colágeno foi claramente evidenciado quando os cortes foram examinados sob luz polarizada. A coloração esverdeada e avermelhada entre as fibras musculares e as lamelas o corpo da mandíbula indicou a presença dos feixes de fibras colágenas (Fig. 52 e 53). Em maior aumento, foram observadas as fibras musculares envoltas pelo endomísio, tecido conjuntivo, corado em verde e vermelho (Fig. 54). 


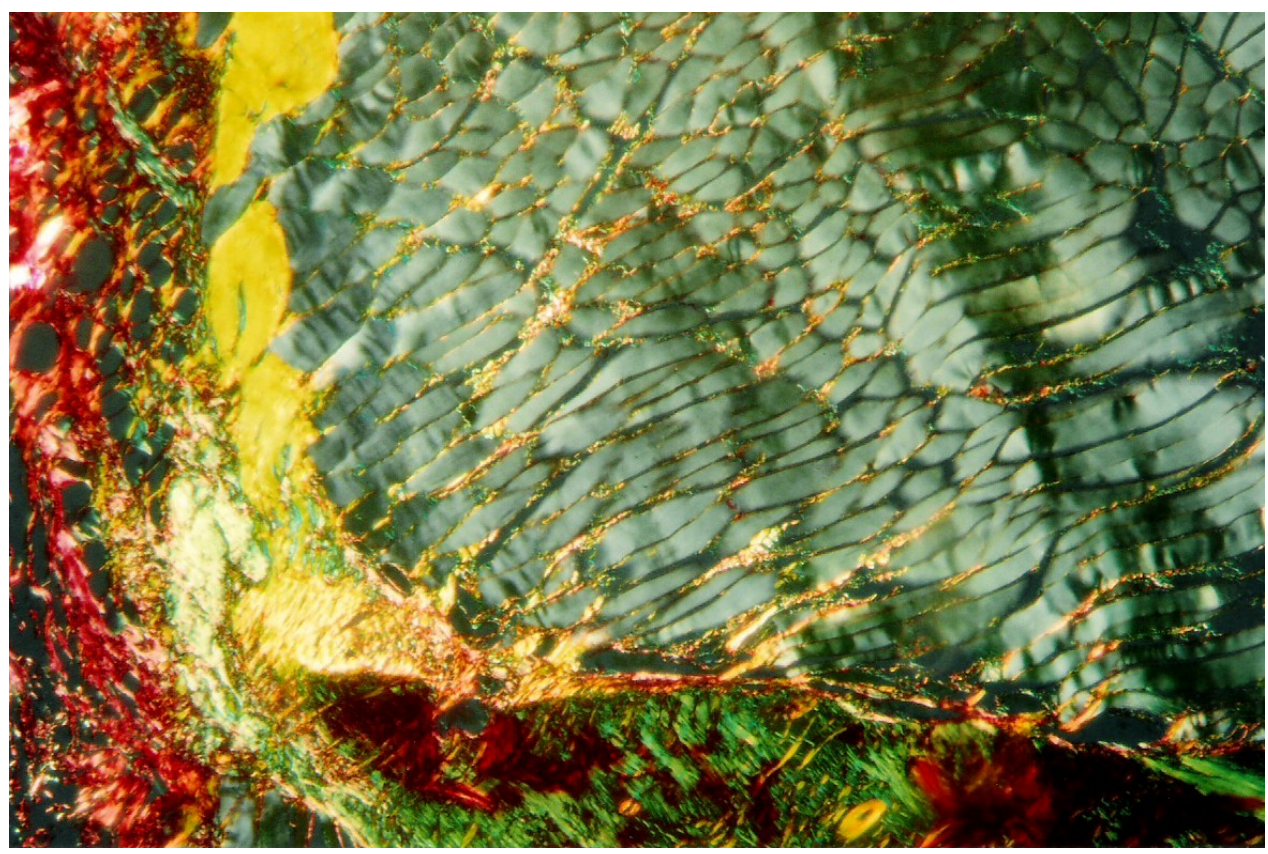

Figura 52. Corte examinado sob luz polarizada revela o aspecto esverdeado e avermelhado que caracterizam o tecido colágeno. 64X Coloração: Picrosirius.

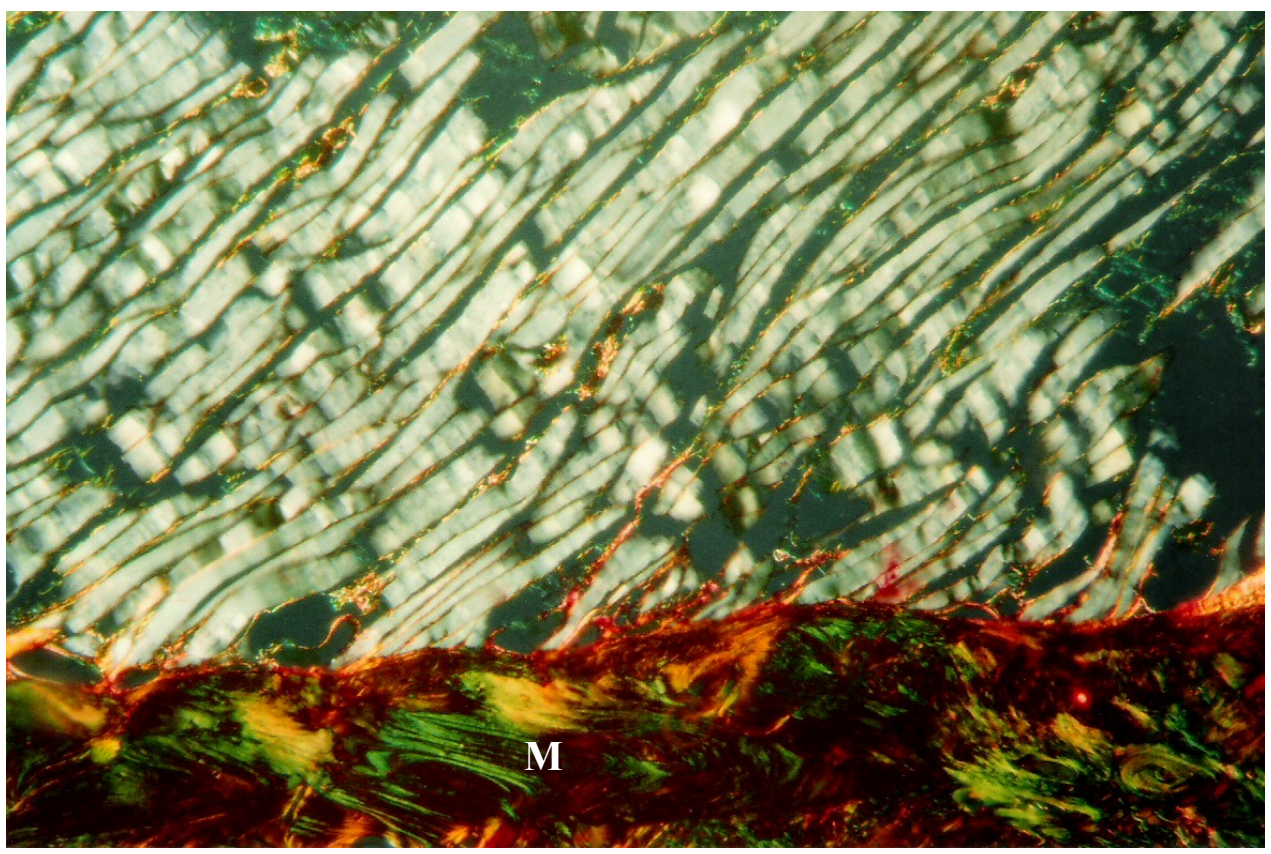

Figura 53. Fotomicrografia de luz polarizada. Mostra as lamelas do corpo da mandíbula (M) evidenciando o tecido conjuntivo de coloração esverdeada e avermelhada indicando a presença de fibras colágenas. Revela as fibras musculares em corte longitudinal. 120X Coloração: Picrosirius. 


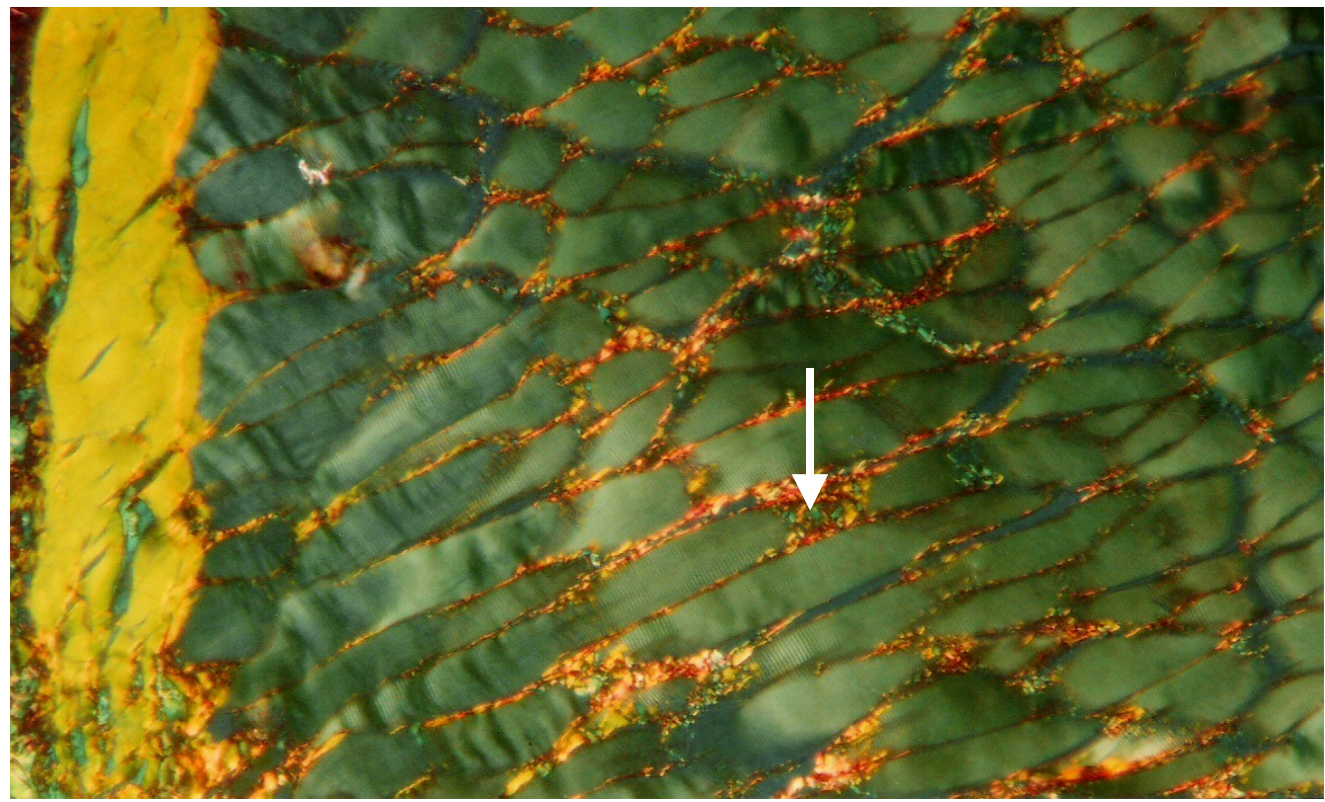

Figura 54. Corte examinado sob luz polarizada. Mostra a presença das fibras colágenas do endomísio coradas em verde e vermelho (seta). 120X Coloração: Picrosirius.

Ao microscópio eletrônico de varredura notaram-se as características da inserção das fibras musculares do pterigóideo medial no ramo da mandíbula (Fig. 55 e 56).

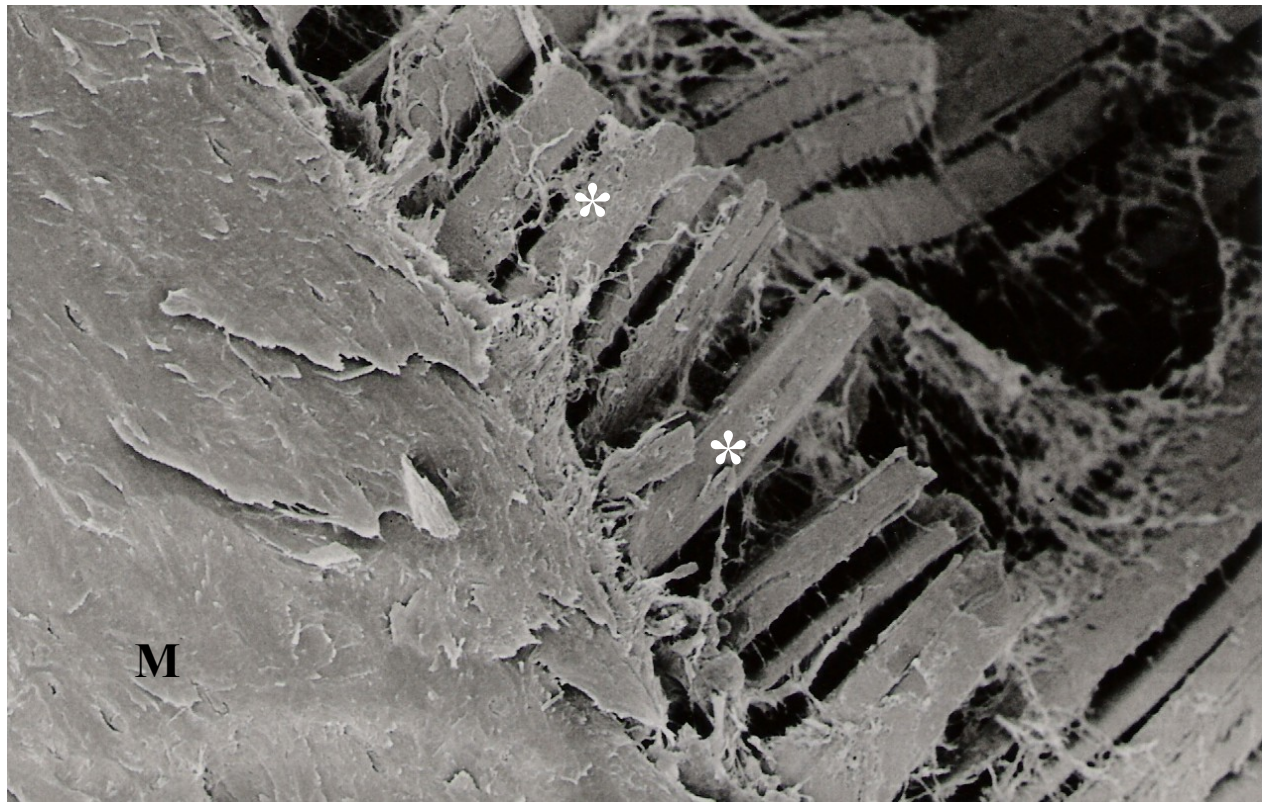

Figura 55. Microscopia eletrônica de varredura. Peça fixada em solução de Karnovsky modificada evidencia as superfície óssea do ângulo da mandíbula (M) e a área de inserção das fibras musculares $\left({ }^{*}\right)$ do pterigóideo medial do rato adulto. 200X. 


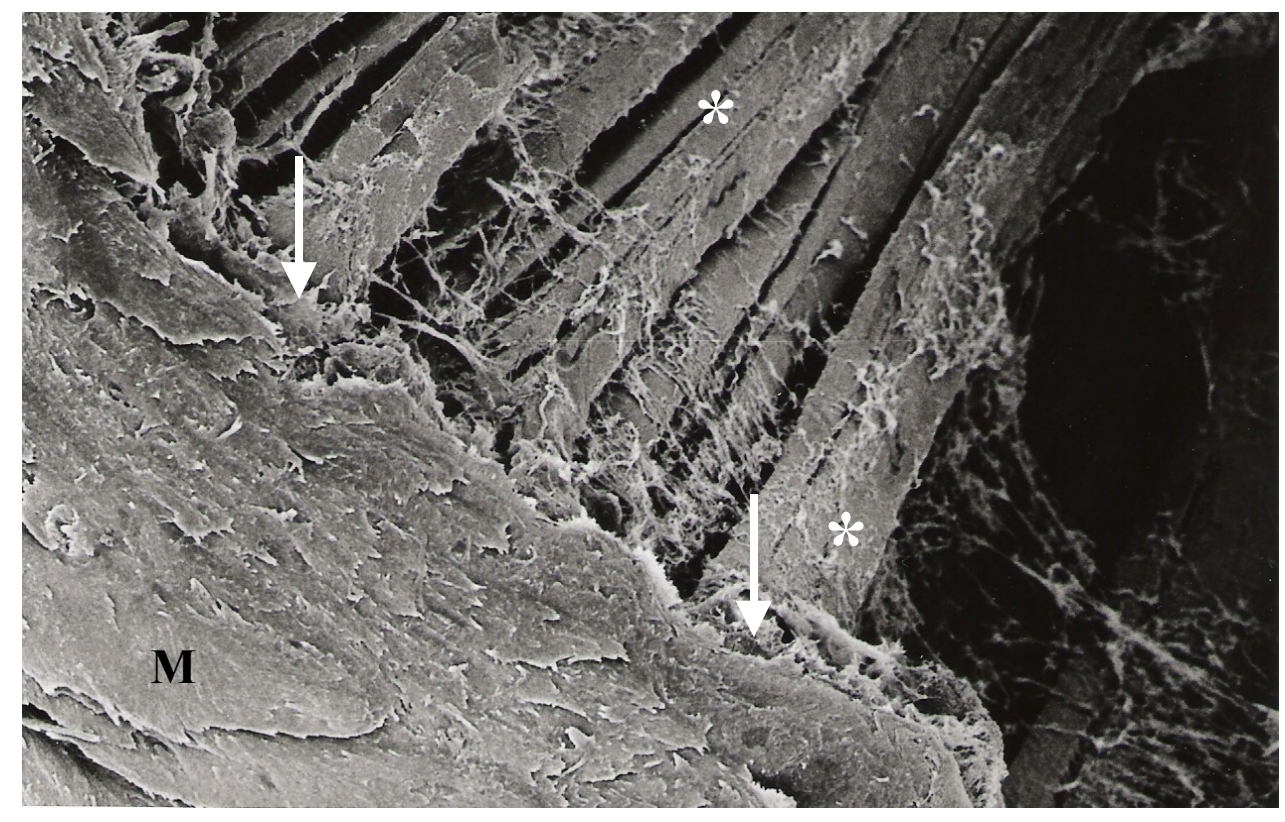

Figura 56. Microscopia eletrônica de varredura. Peça fixada em solução de Karnovsky modificada. Mostra as fibras longitudinais do músculo $\left(^{*}\right)$ inserindo-se na face interna do ângulo da mandíbula $(\mathrm{M})$ através de fibras colágenas (setas). 200X.

As fibras musculares foram observadas em cortes longitudinais e transversais podendo-se notar suas espessuras e diâmetros (Fig. 57 e 58) e na superfície óssea notaram-se os forames nutrícios (Fig. 59).

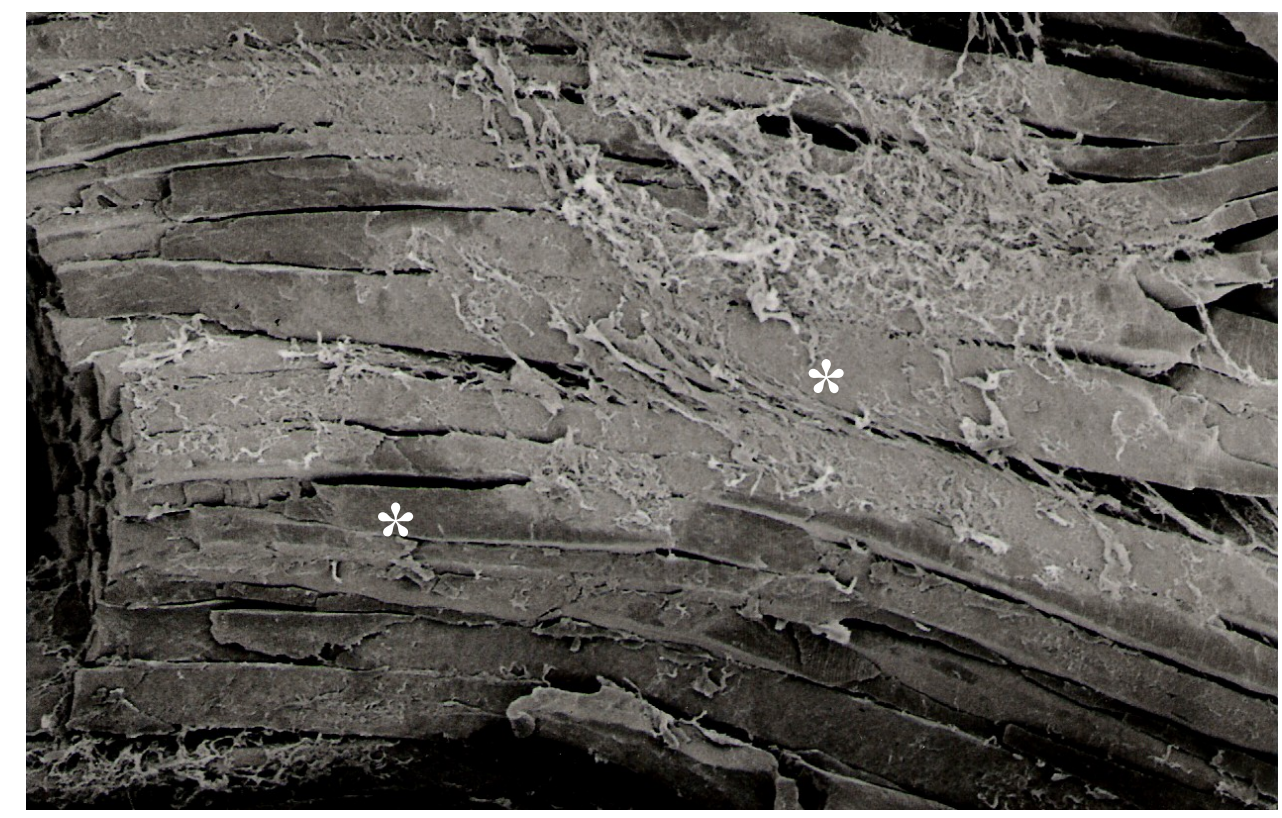

Figura 57. Microscopia eletrônica de varredura. Observam-se as fibras musculares $\left(^{*}\right)$ dispostas longitudinalmente. 200X. 


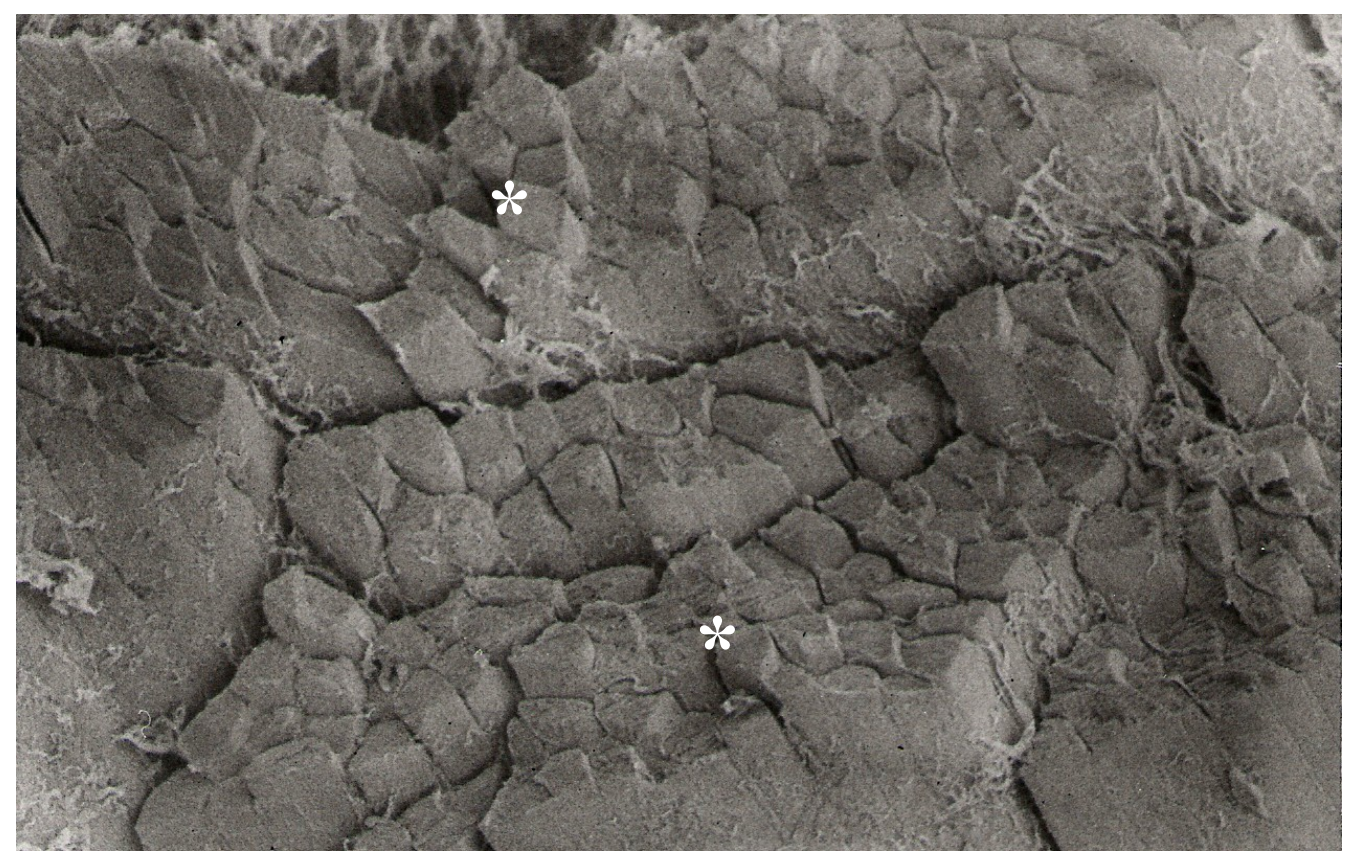

Figura 58. Microscopia eletrônica de varredura. Peça fixada em solução de Karnovsky modificada evidencia, em mesmo aumento, os feixes de fibras $\left({ }^{*}\right)$ em corte transversal. 200X.

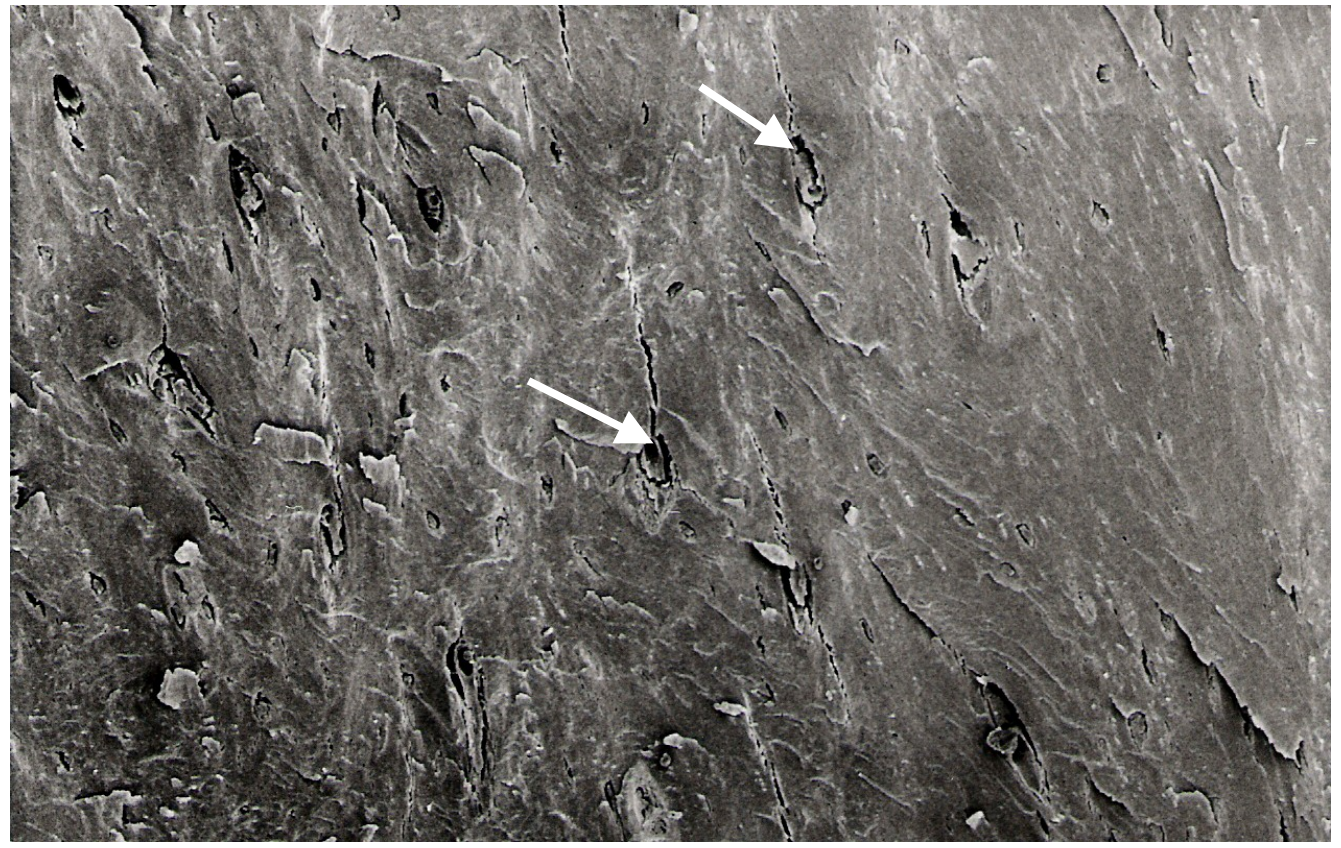

Figura 59. Microscopia eletrônica de varredura. Peça fixada em solução de Karnovsky modificada. Na superfície da mandíbula podem-se notar os forames nutrícios (setas). $200 X$. 
Em maior aumento, a área de inserção muscular foi evidenciada e pôde-se observar a presença do tecido colágeno da região (Fig. 60 e 61).

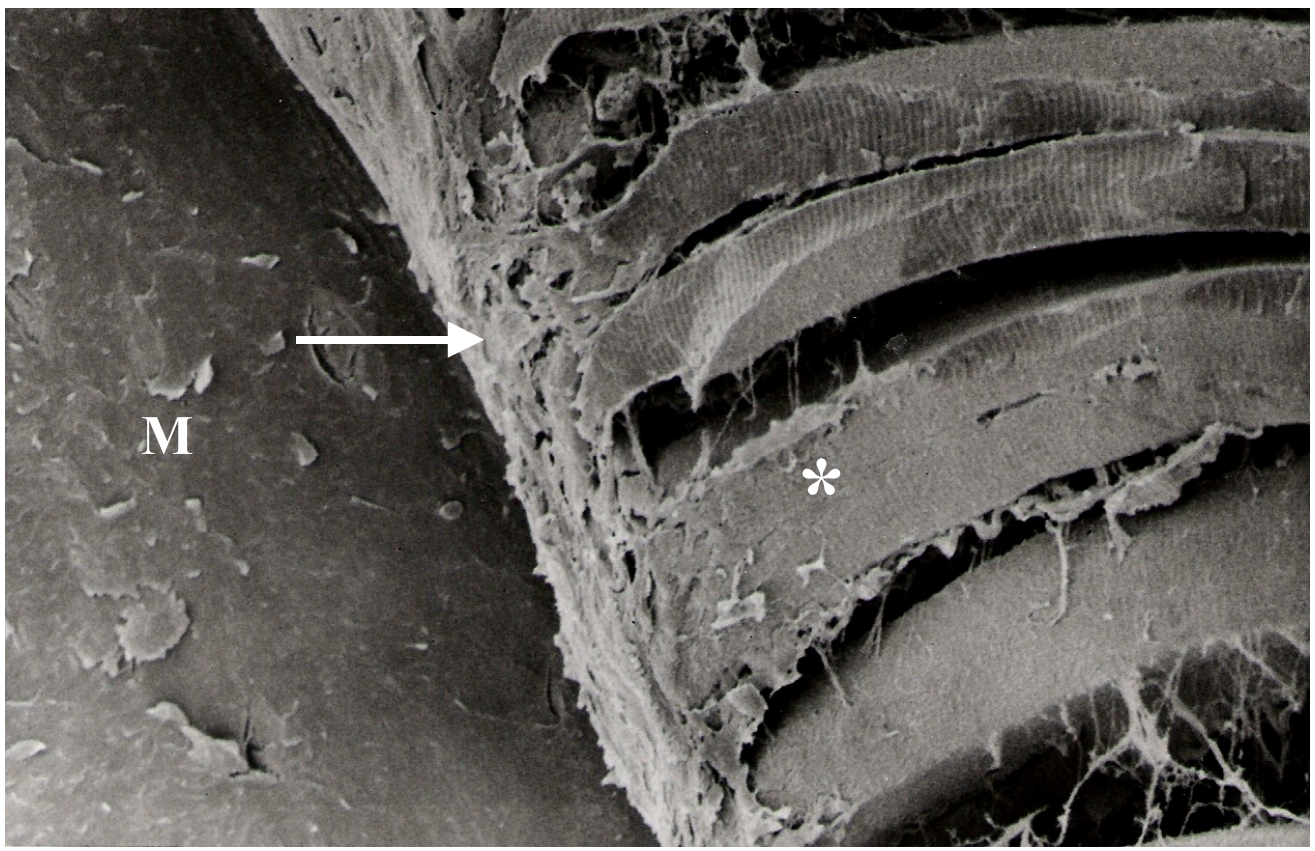

Figura 60. Microscopia eletrônica de varredura. Em maior aumento, observa-se a área de inserção (seta) das fibras musculares $\left(^{*}\right)$ do pterigóideo medial de rato adulto na superfície óssea do ângulo mandibular (M) e o tecido colágeno presente entre as fibras. 500X.

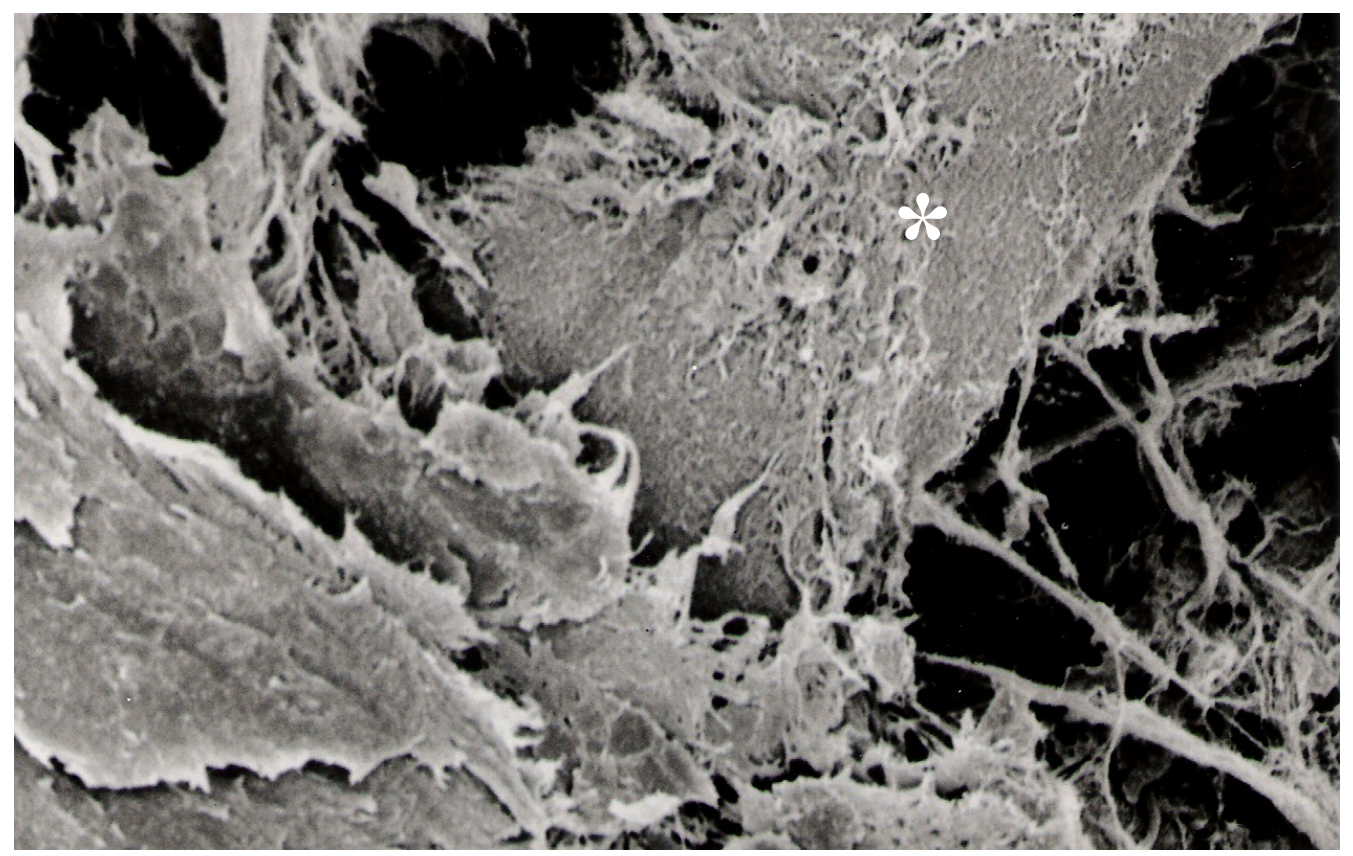

Figura 61. Microscopia eletrônica de varredura. Peça fixada em solução de Karnovsky modificada evidencia a inserção da fibra muscular (*) no tecido ósseo. 800X. 
Seguindo em maior aumento, as fibras musculares foram examinadas em corte transversais (Fig. 62) e longitudinais que revelaram as estriações características do músculo esquelético (Fig. 63 e 64) e o tecido colágeno entre as fibras.

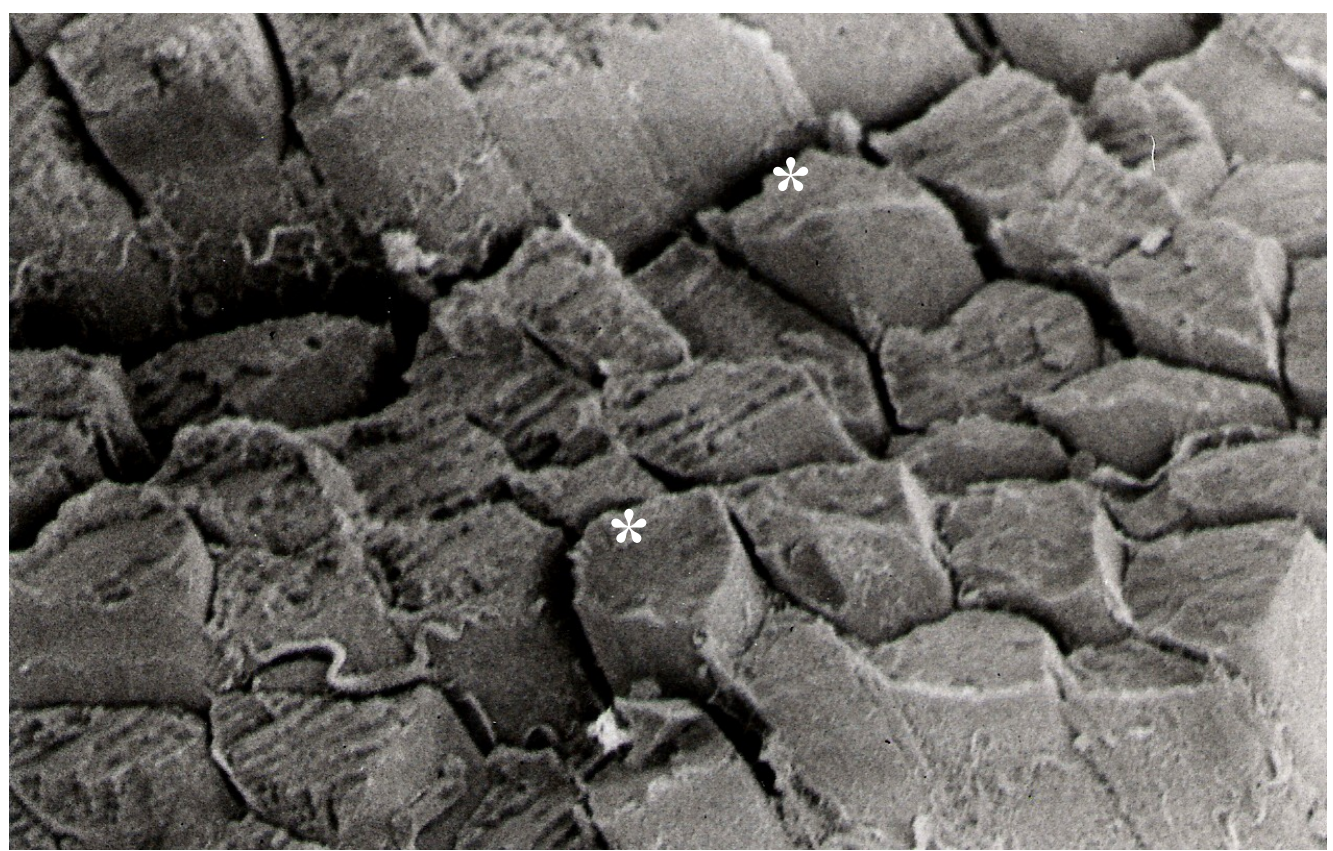

Figura 62. Microscopia eletrônica de varredura. Observa-se a fratura transversal das fibras musculares $\left({ }^{*}\right)$ em maior aumento. 600X.

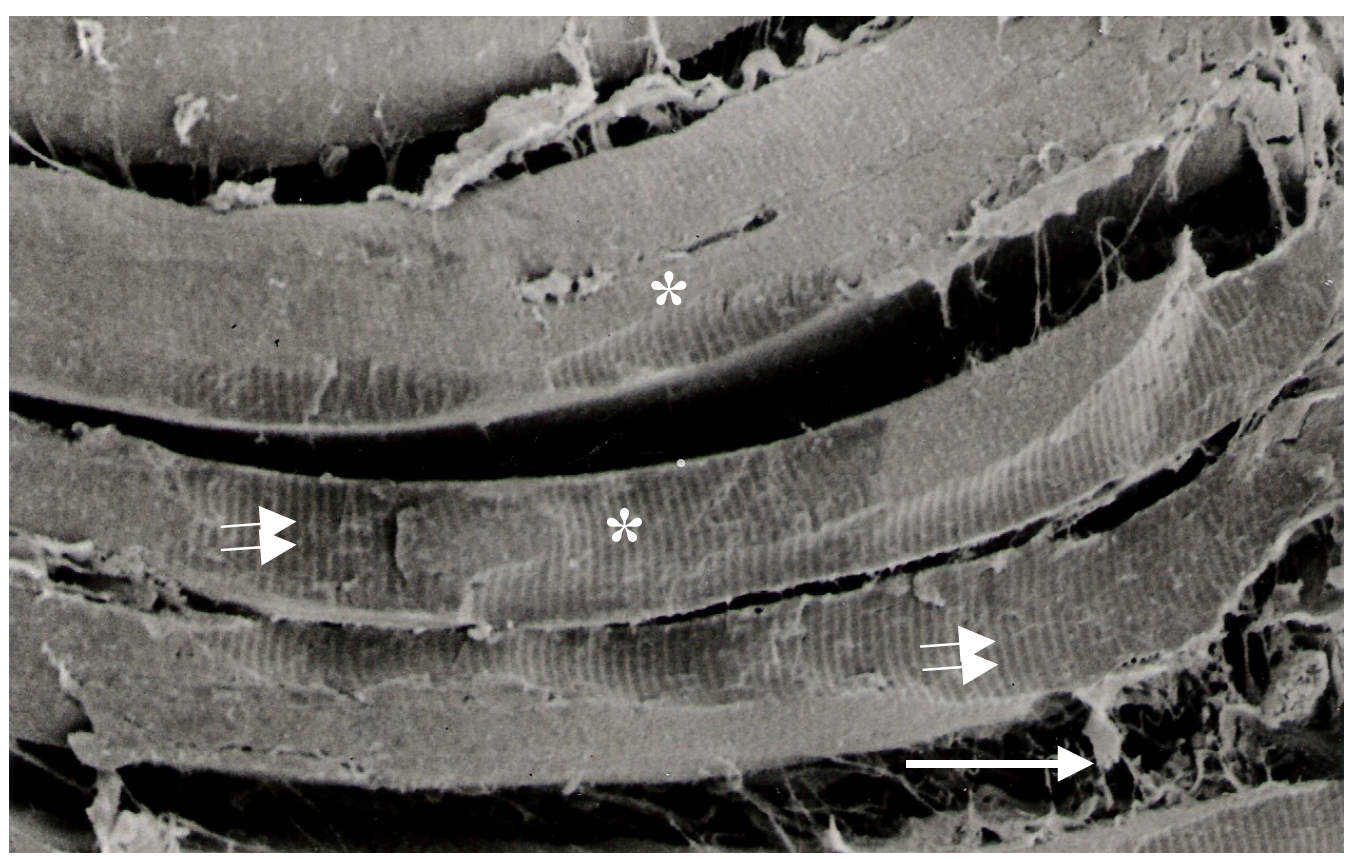

Figura 63. Microscopia eletrônica de varredura. Fratura longitudinal das fibras do pterigóideo medial $\left(^{*}\right)$. Nota-se a presença de estriações (duas setas) que caracterizam os músculos esqueléticos e o tecido colágeno entre as fibras (seta). 700X. 


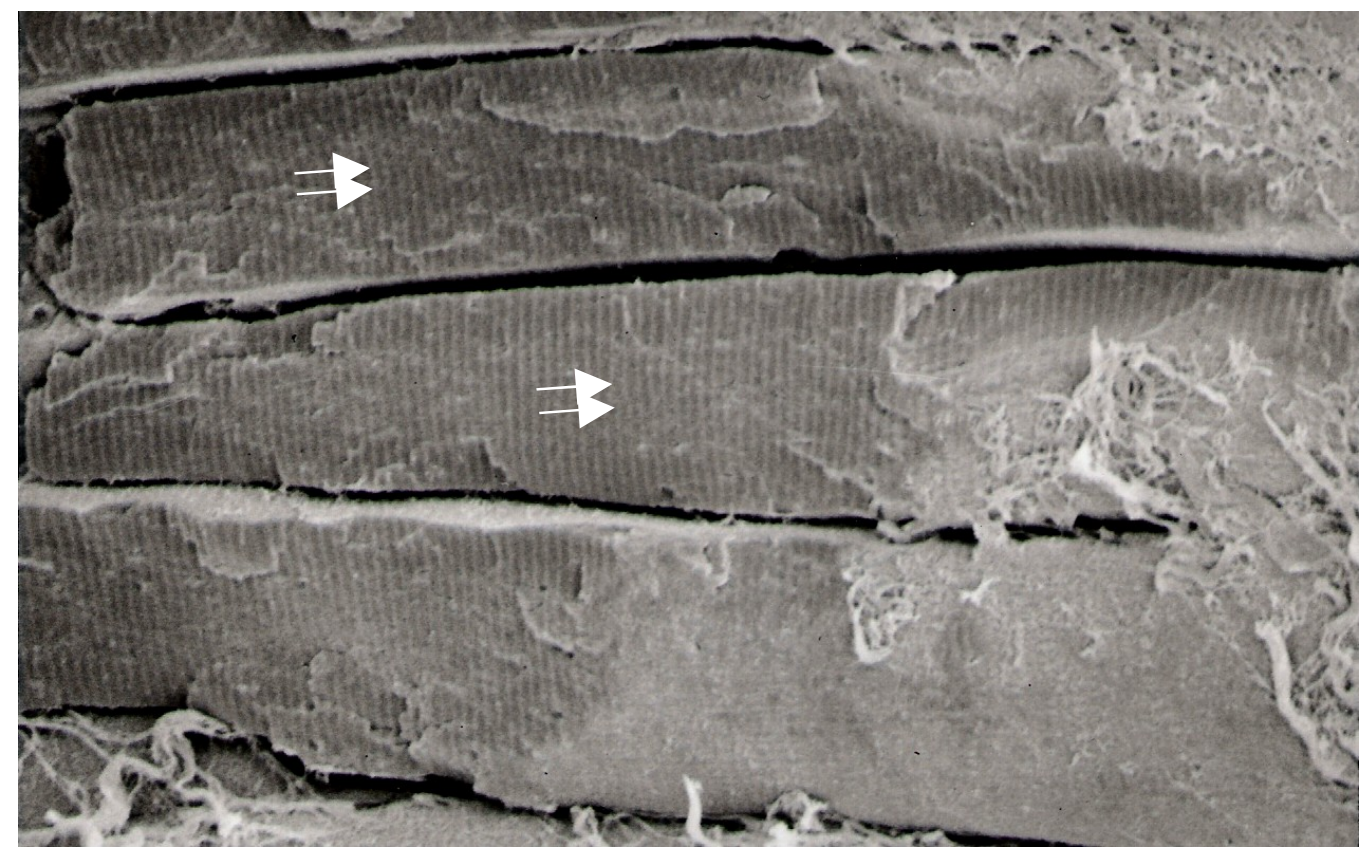

Figura 64. Microscopia eletrônica de varredura. Peça fixada em solução de Karnovsky modificada. Em maior aumento evidencia as estriações (duas setas) da fibra muscular. 800X.

Nas peças tratadas com solução de $\mathrm{NaOH}$, após a remoção das células musculares, o tecido colágeno do endomísio foi evidenciado"in situ" (Fig. 65, 66 e 67). Os feixes de fibras colágenas foram observados em cortes transversais e longitudinais em maior e menor aumento revelando a espessura das paredes das lojas que continham as fibras musculares. 


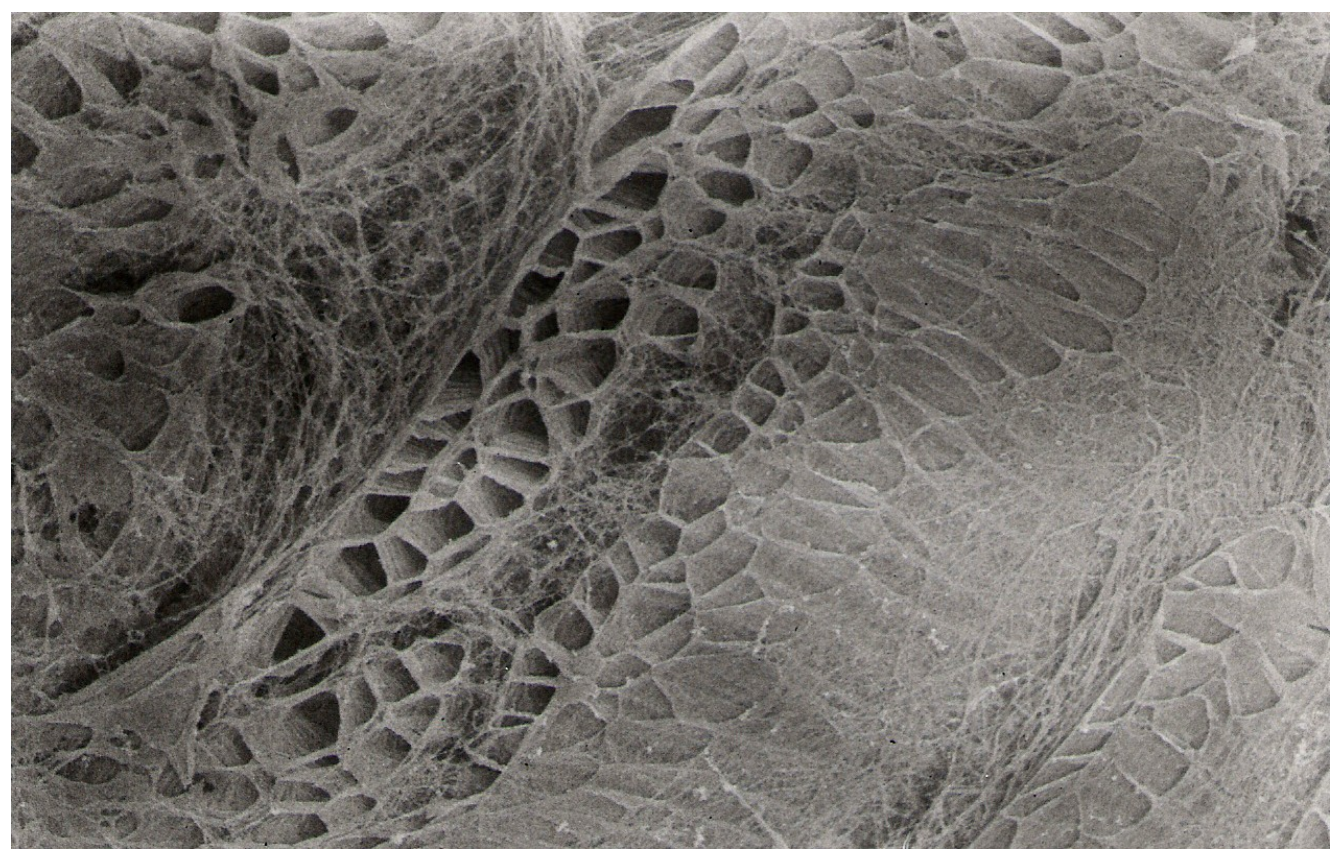

Figura 65. Microscopia eletrônica de varredura. Amostra tratada com solução de $\mathrm{NaOH}$, revela o endomísio composto de tecido colágeno que envolve cada fibra muscular. Corte transversal. 100X.

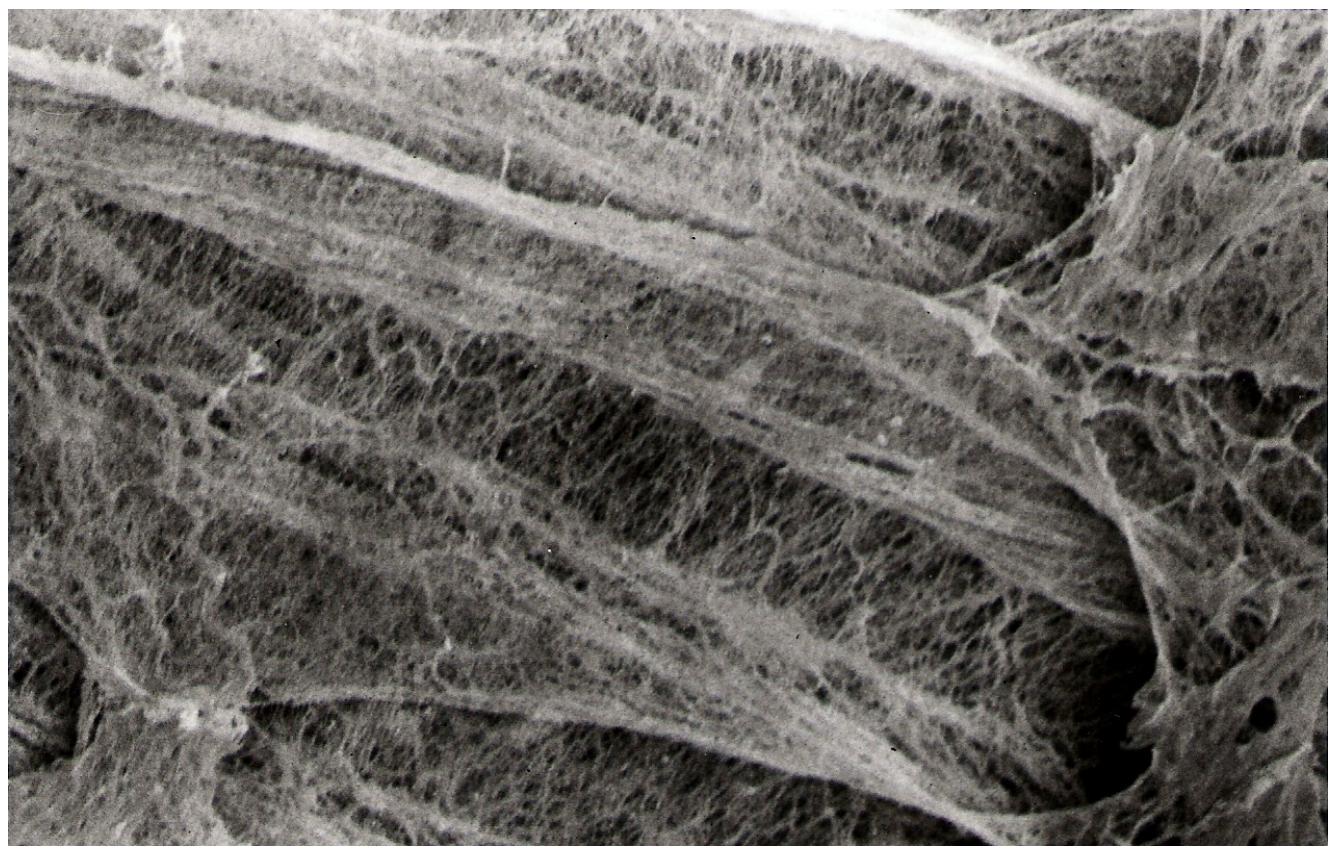

Figura 66. Microscopia eletrônica de varredura. Amostra tratada com solução de $\mathrm{NaOH}$, mostra em maior aumento o endomísio revelando a disposição do tecido colágeno. Corte longitudinal. 550X. 


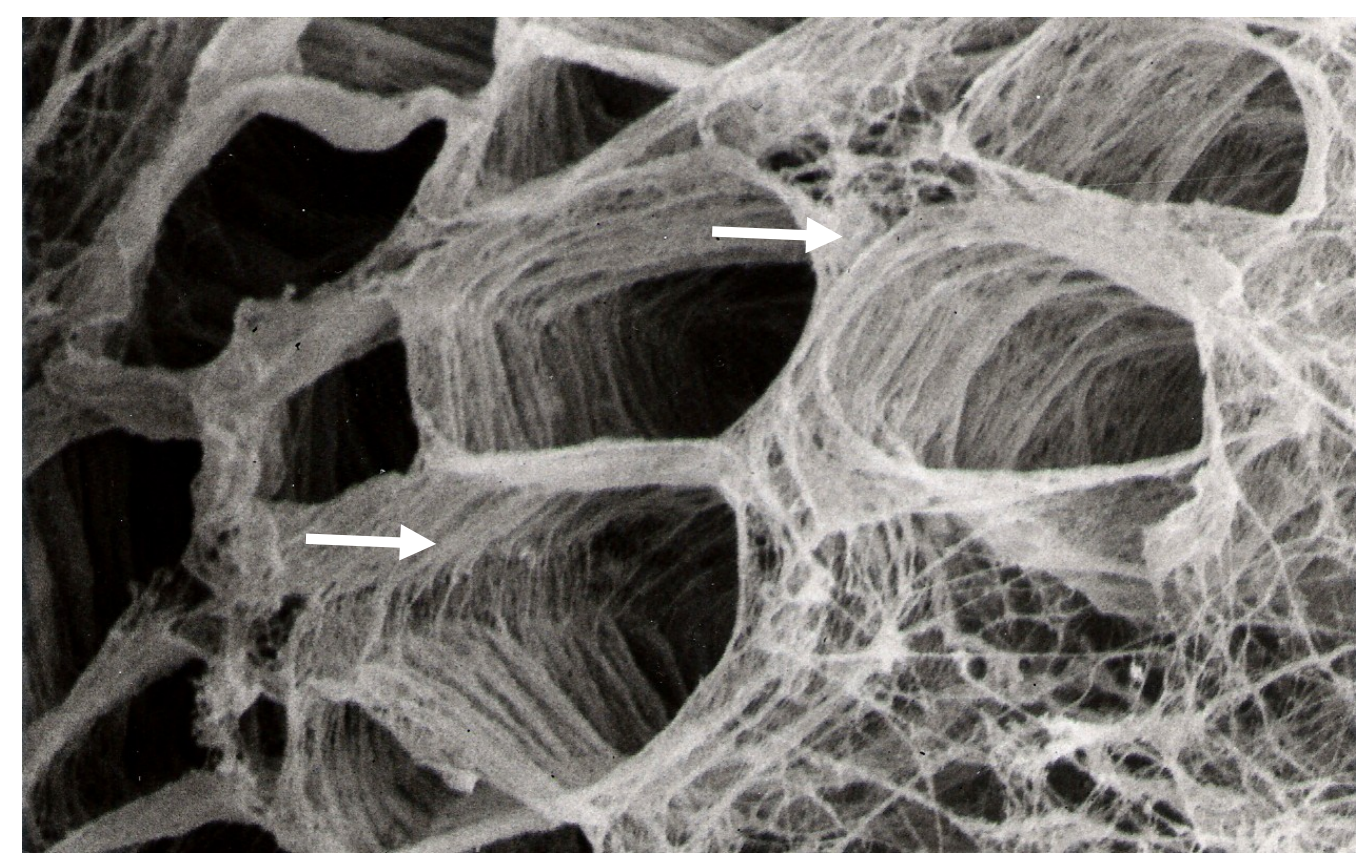

Figura 67. Microscopia eletrônica de varredura. Amostra tratada com solução de $\mathrm{NaOH}$, em corte transversal, mostra as redes de tecido colágeno e o endomísio (setas). 550X.

A observação ao microscópio eletrônico de transmissão das peças fixadas em solução de Karnovsky modificada, pós-fixada em tetróxido de ósmio e incluídas em resina Spurr mostrou o aspecto geral da fibra muscular em corte longitudinal (Fig. 68) e a disposição dos sarcômeros entremeados por mitocôndrias (Fig. 69). 


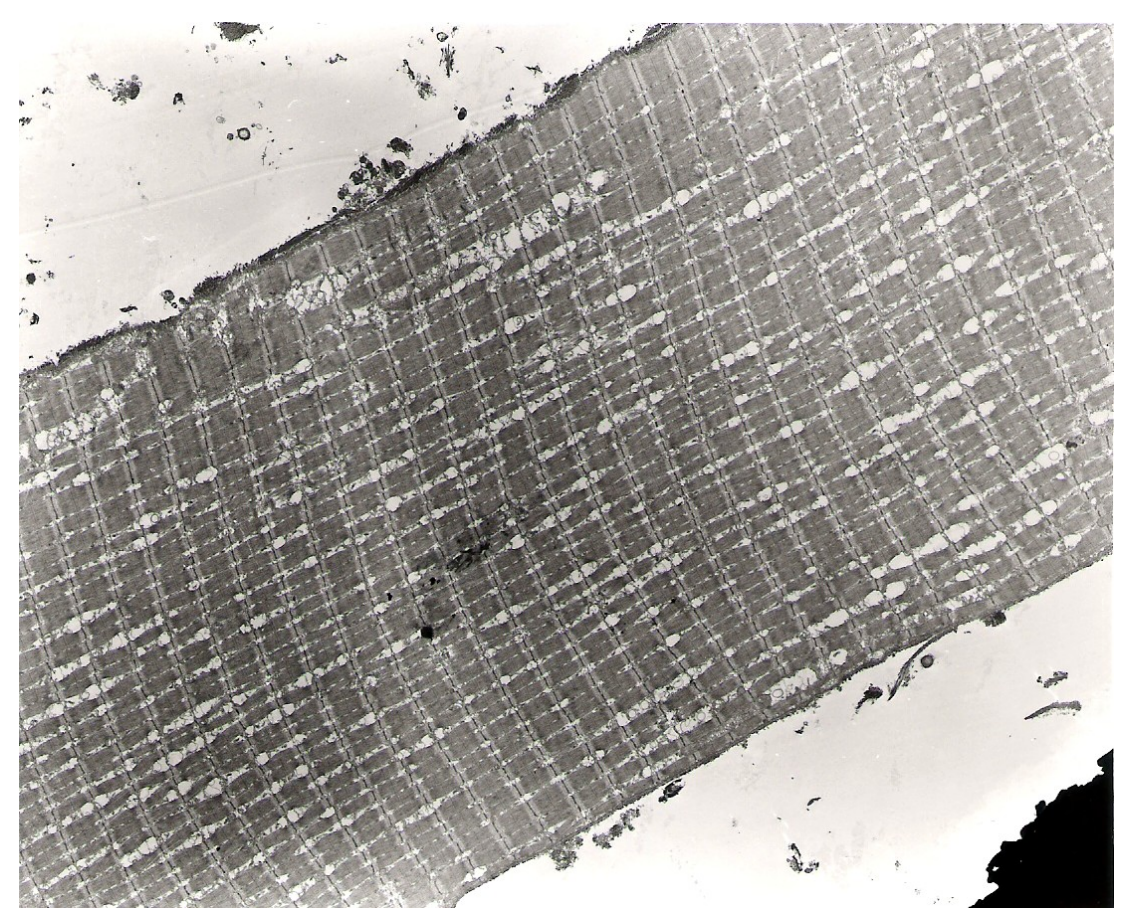

Figura 68. Microscopia eletrônica de transmissão. Músculo pterigóideo medial de rato adulto fixado em solução de Karnovsky modificada, pós-fixada em tetróxido de ósmio e incluída em resina Spurr. Mostra o aspecto geral da fibra muscular e os sarcômeros, evidenciando as bandas I, Z e A. $2.000 \mathrm{X}$.

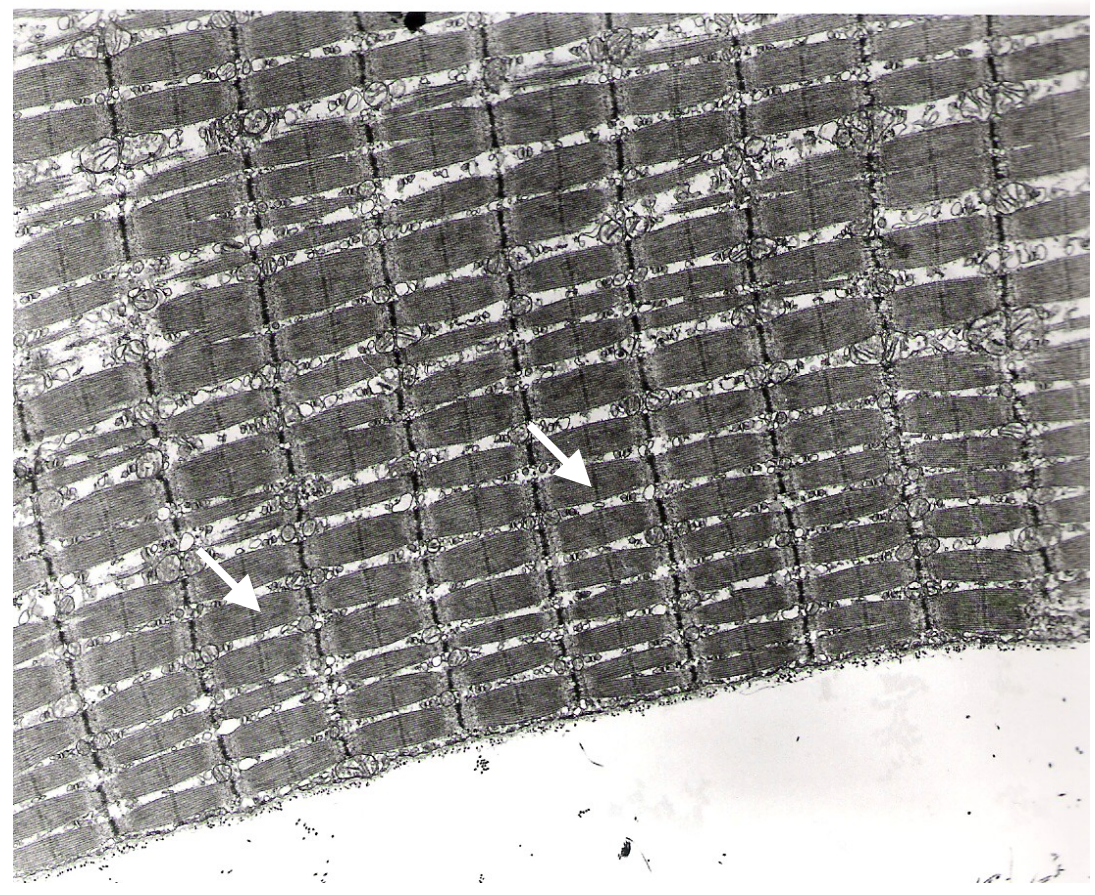

Figura 69. Microscopia eletrônica de transmissão. Músculo pterigóideo medial de rato adulto fixado em solução de Karnovsky modificada, pós-fixada em tetróxido de ósmio e incluída em resina Spurr. Mostra a fibra muscular em corte longitudinal com seus sarcômeros (setas) entremeados por mitocôndria. 6.000X. 
Em maior aumento, observaram-se os sarcômeros, as linhas e bandas e as mitocôndrias entremeando-se às miofibrilas (Fig. 70 e 71).

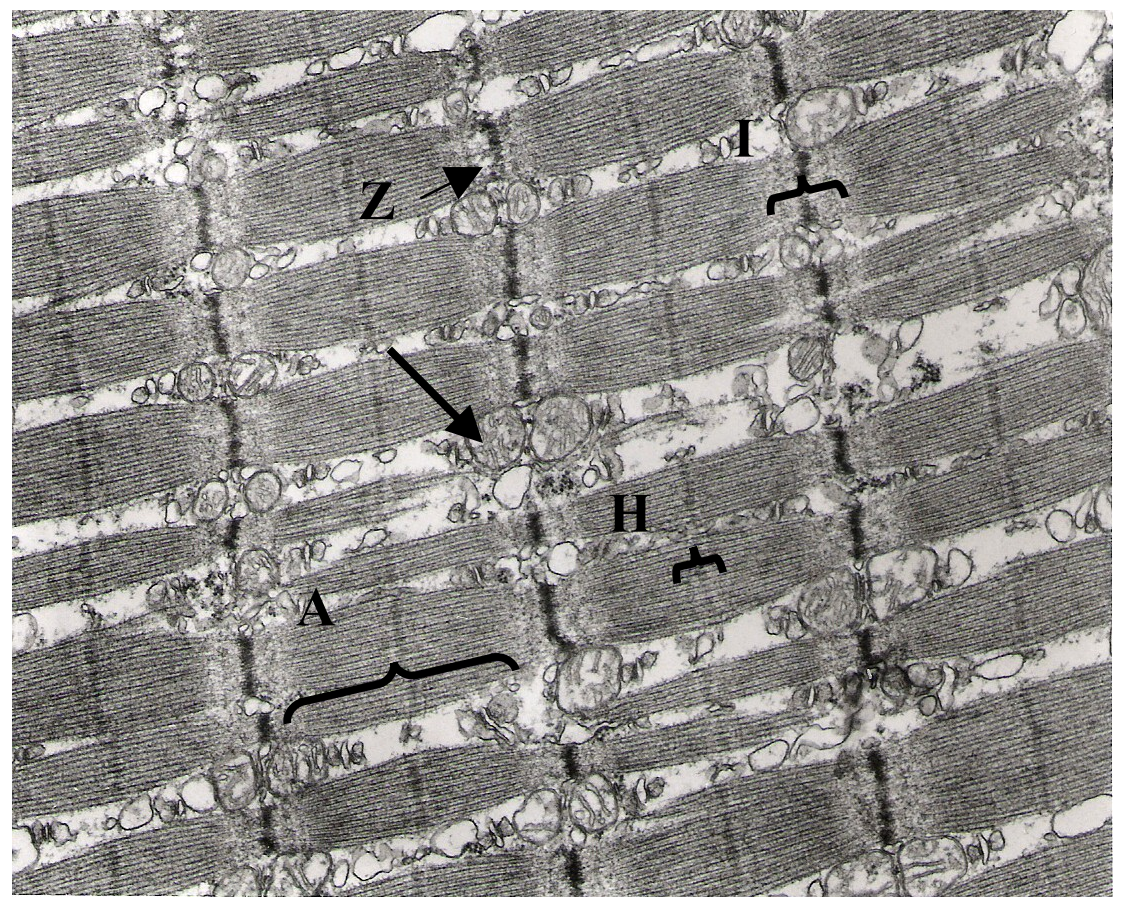

Figura 70. Microscopia eletrônica de transmissão. Músculo pterigóideo medial de rato adulto fixado em solução de Karnovsky modificada, pós-fixada em tetróxido de ósmio e incluída em resina Spurr. Notam-se, em corte longitudinal, as mitocôndrias (seta) entremeando-se às miofibrilas e a disposição dos sarcômeros e suas regiões de bandas $A, H, I$ e Z.15.000X. 


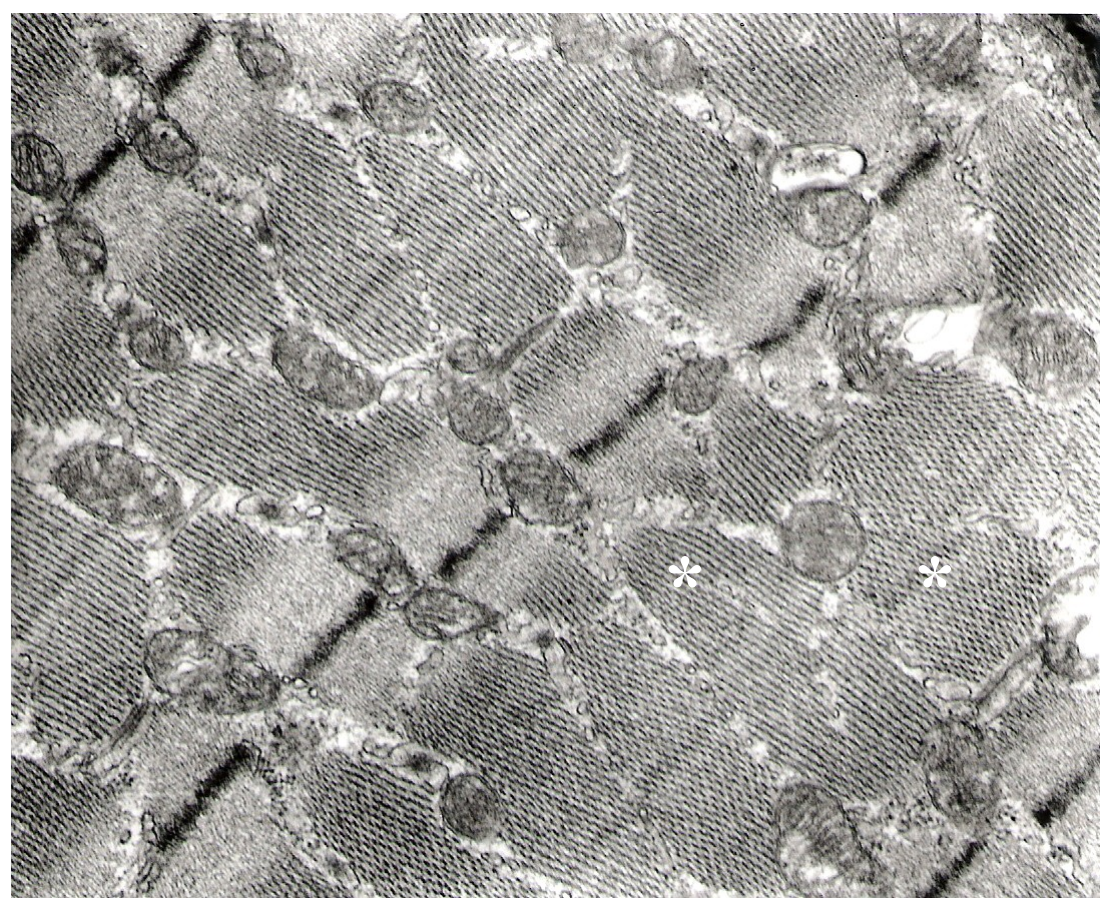

Figura 71. Microscopia eletrônica de transmissão. Músculo pterigóideo medial de rato adulto. Podem-se notar os feixes de miofibrilas $\left(^{*}\right) .20 .000 \mathrm{X}$.

Notou-se o núcleo na porção periférica da célula muscular (Fig. 72) e, em maior aumento, notamos os numerosos feixes de miofibrilas entremeados por mitocôndrias (Fig. 73). 


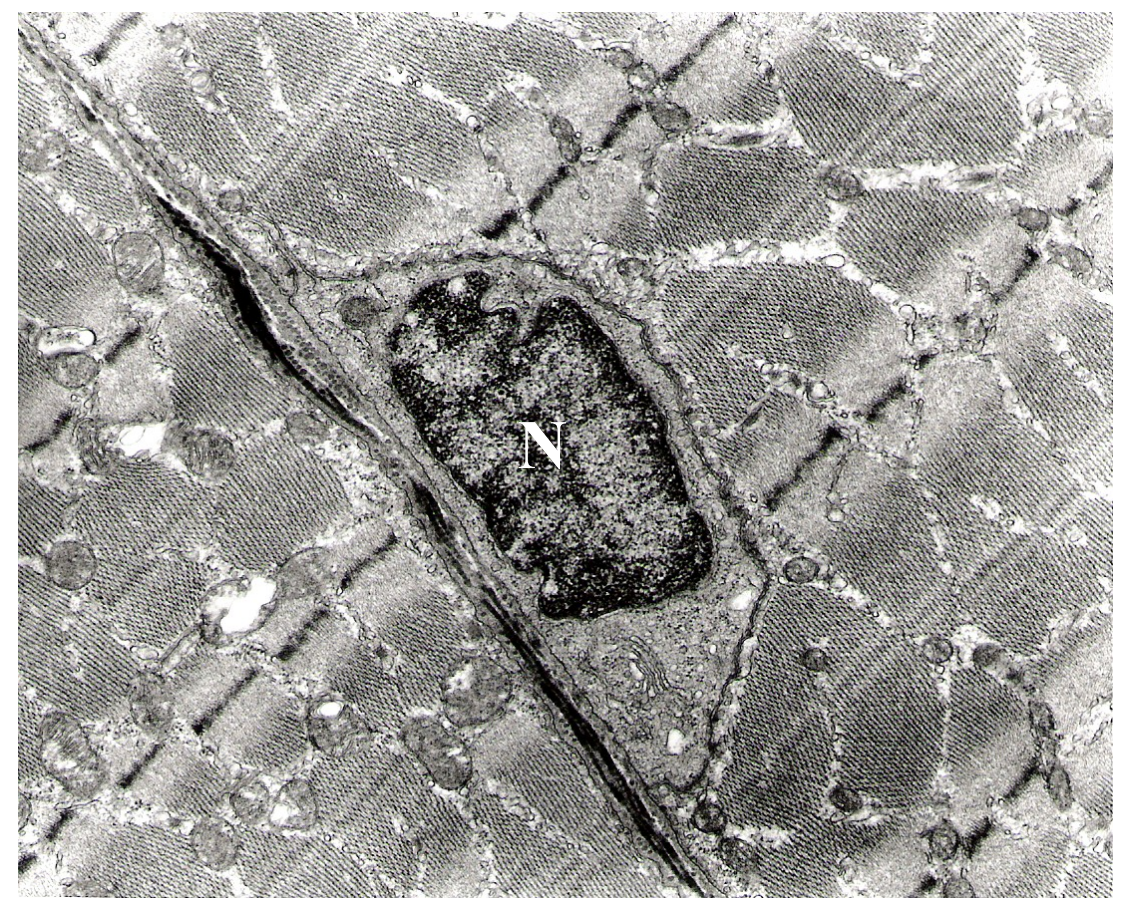

Figura 72. Microscopia eletrônica de transmissão. Músculo pterigóideo medial de rato adulto. Observa-se o núcleo $(\mathrm{N})$ da célula muscular localizado na sua porção periférica. $12.000 \mathrm{X}$.

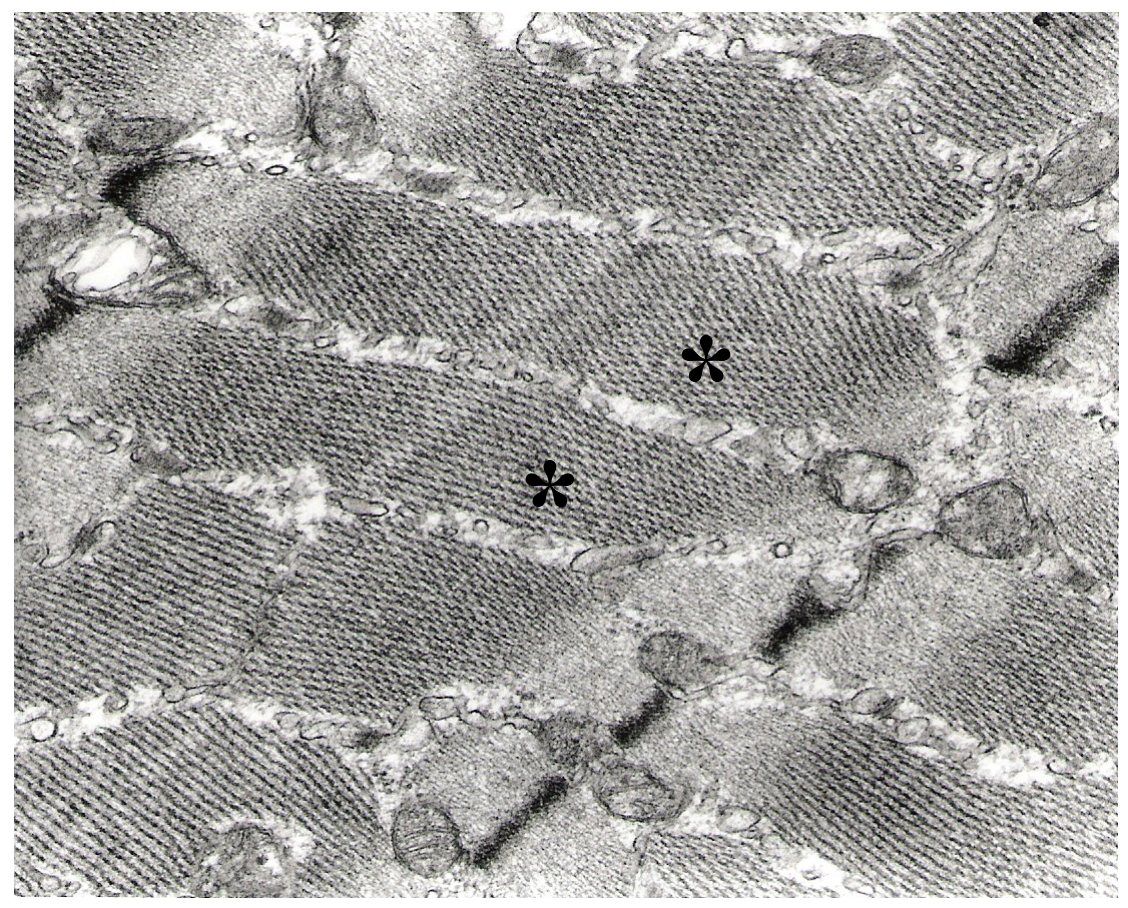

Figura 73. Microscopia eletrônica de transmissão. Músculo pterigóideo medial de rato adulto. Revela as mitocôndrias e suas cristas com dupla membrana entre os feixes de miofibrilas $\left({ }^{*}\right)$. 25.000X. 
Quando observamos a região da junção miotendínea, notamos as interdigitações formadas pela invaginação das fibras tendíneas nas fibras musculares do pterigóideo medial aumentando a superfície de contato entre músculo e tendão. (Fig. 74 e 75).

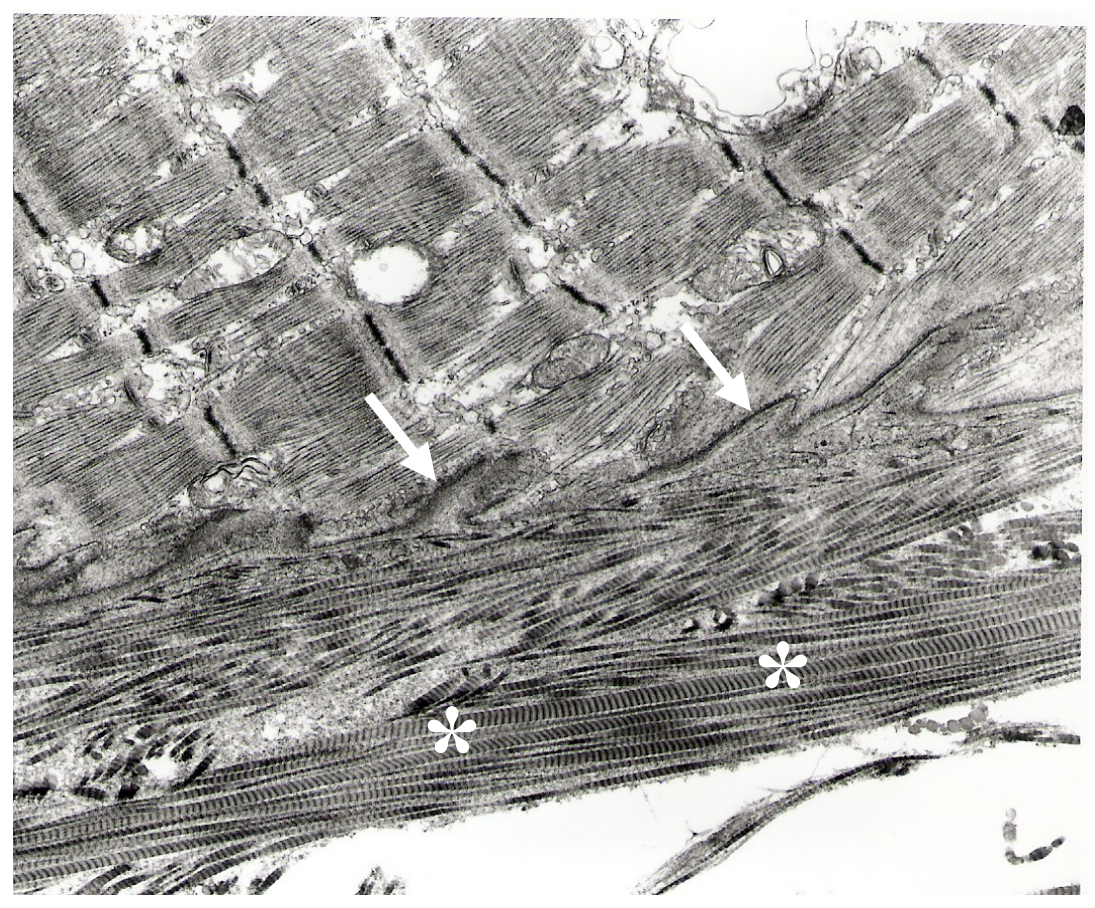

Figura 74. Microscopia eletrônica de transmissão. Observa-se a junção miotendínea do músculo pterigóideo medial de rato adulto (setas). Nas áreas adjacentes notam-se feixes de fibras colágenas do endomísio dispostos longitudinalmente $\left({ }^{*}\right)$ e obliquamente $10.000 \mathrm{X}$. 


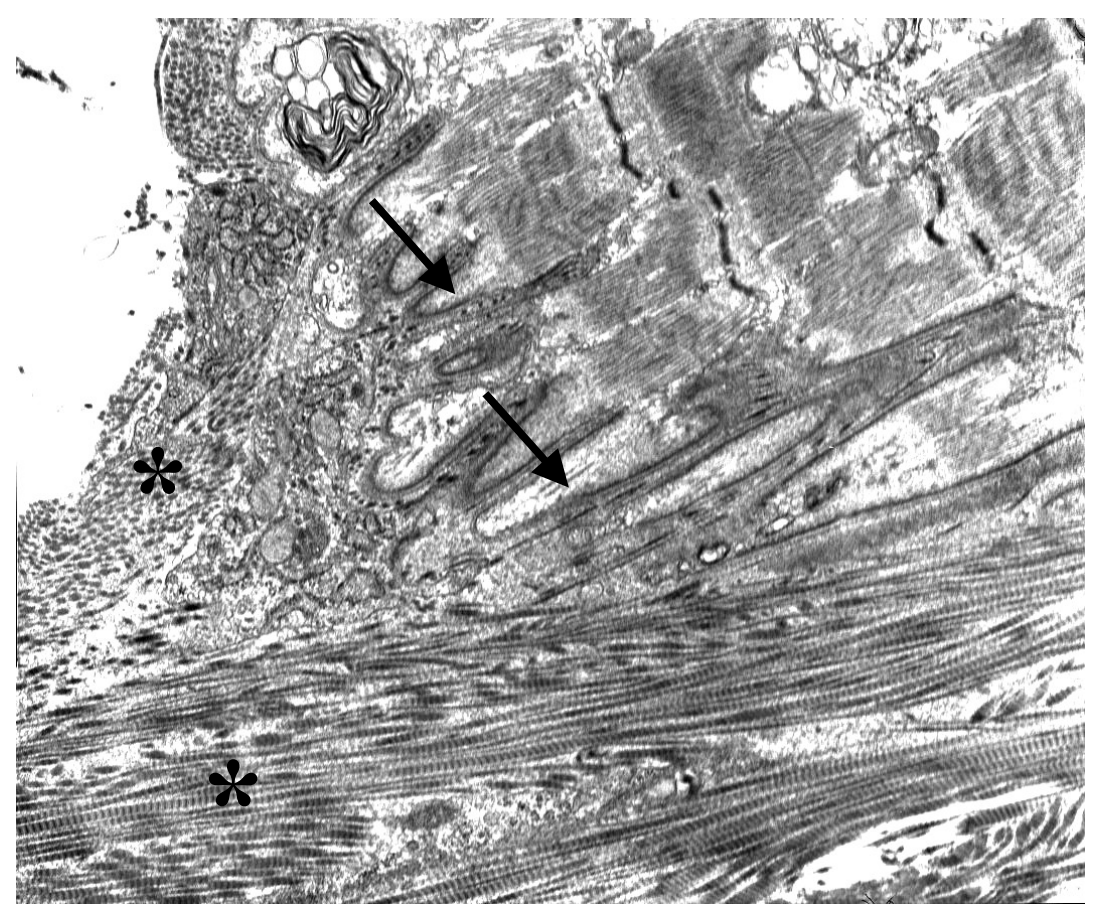

Figura 75. Microscopia eletrônica de transmissão. Observam-se as interdigitações da junção miotendínea em forma de dedos (setas) e fibras colágenas adjacentes $\left(^{*}\right)$. 10.000X.

Nota-se que em algumas regiões, estes prolongamento formam redes e "galhos" (Fig.76, 77 e 78).

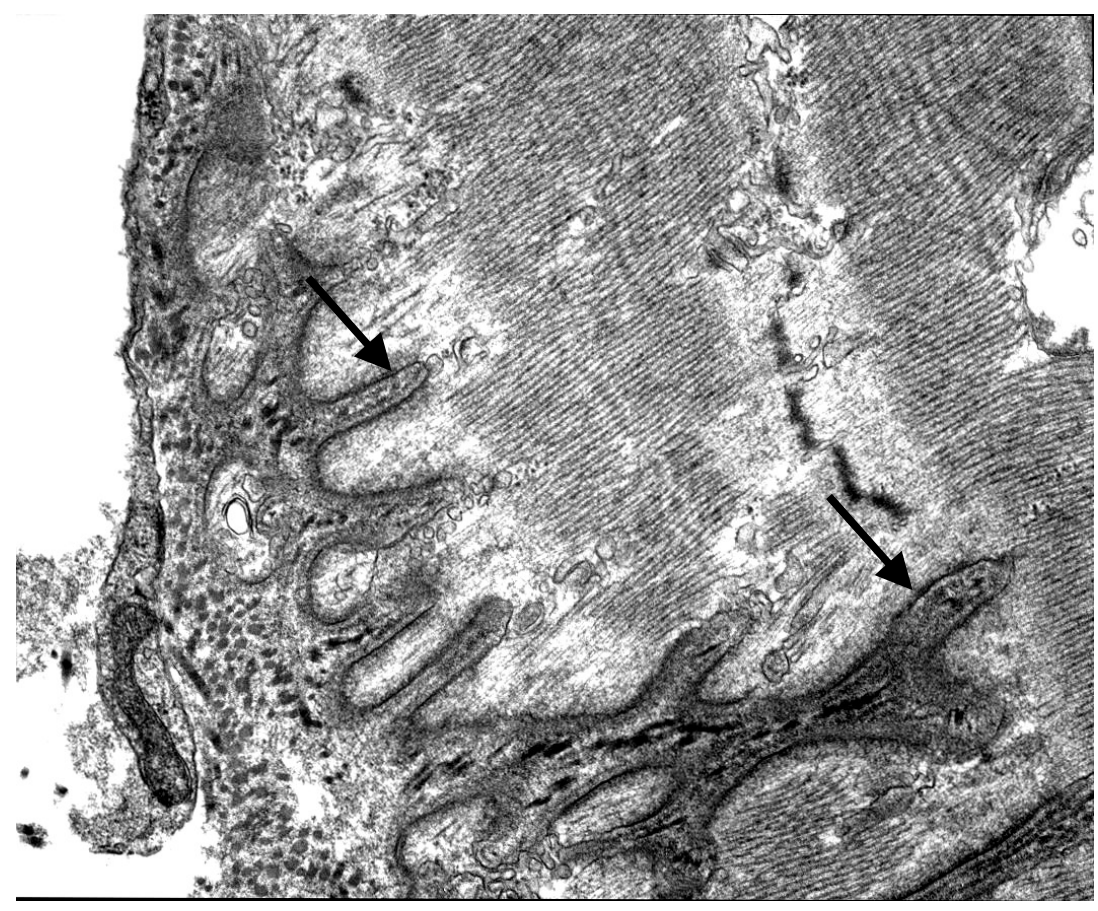

Figura 76. Microscopia eletrônica de transmissão. Revela os feixes de miofibrilas do músculo pterigóideo medial de rato adulto interdigitando-se com as projeções de diferentes tamanhos (setas). 20.000X. 


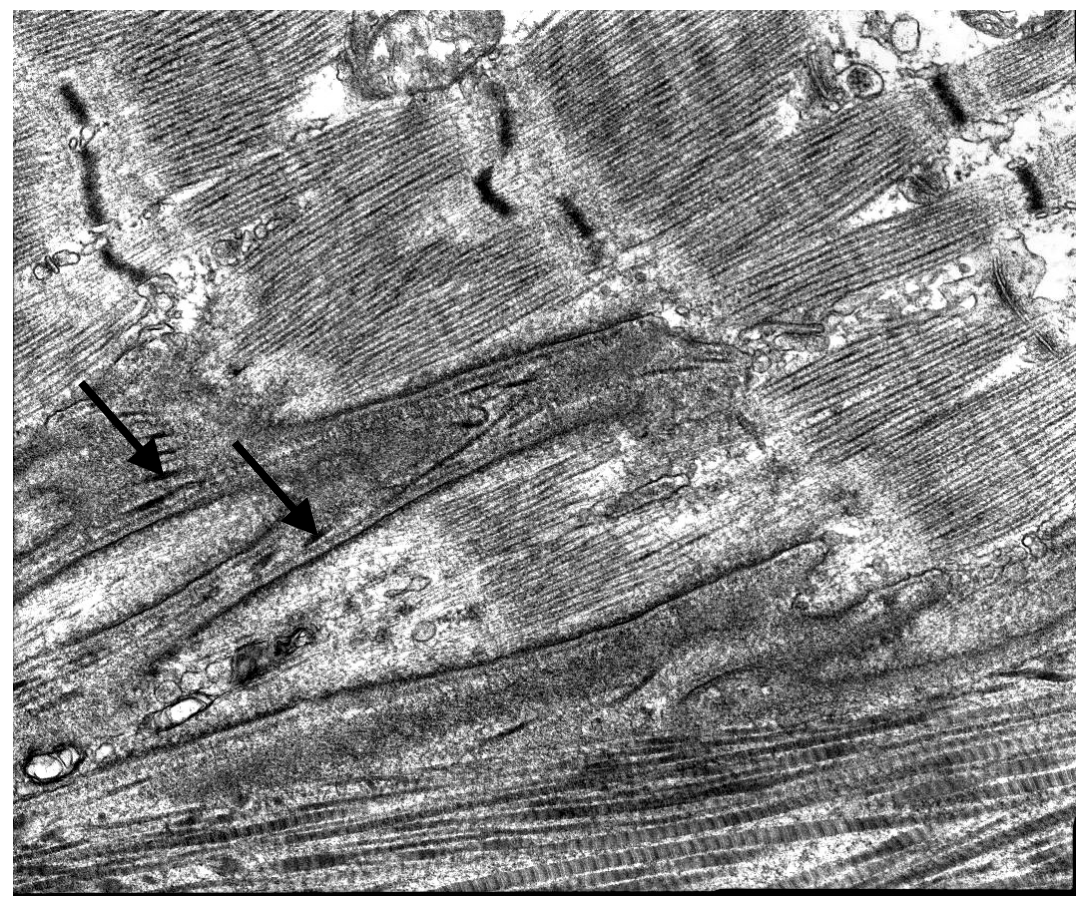

Figura 77. Microscopia eletrônica de transmissão. As fibras colágenas (setas) podem ser visualizadas entre os feixes de miofibrilas. 20.000X.

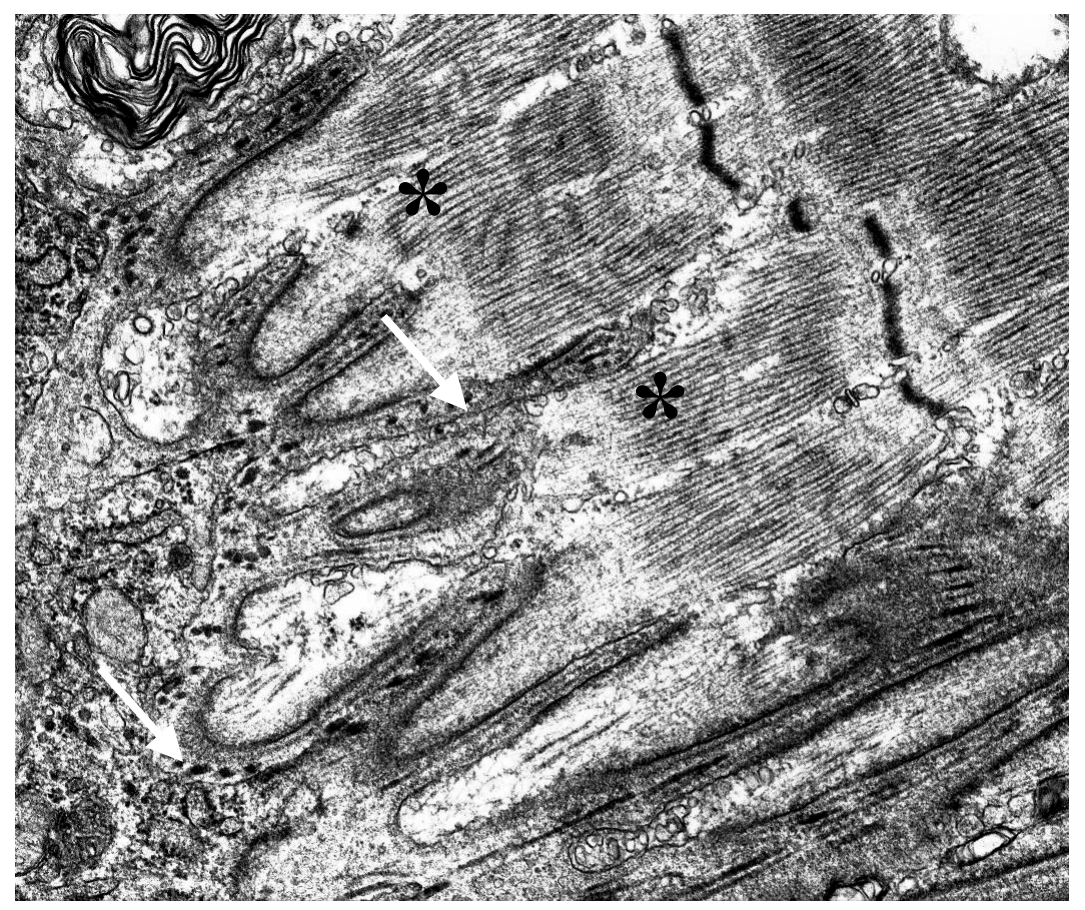

Figura 78. Microscopia eletrônica de transmissão. Em maior aumento observamos as miofibrilas $\left({ }^{*}\right)$ e fibrilas colágenas (setas). 20.000X. 
5 DISCUSSÃO 
Os nossos resultados revelam claramente os aspectos histológicos das estruturas de feixes de fibras musculares do músculo pterigóideo medial de ratos com envelhecimento e de ratos adultos.

Notou-se que o tecido conjuntivo apresenta uma camada espessa dispondo-se entre a camada muscular e tecido ósseo adjacente onde se inserem as fibras do tecido conjuntivo. Os resultados revelam que o tecido colágeno presente na área de inserção é maior no rato com envelhecimento quando se faz uma avaliação qualitativa. As imagens observadas com a coloração de Picrosirius e examinadas sob luz polarizada confirmam a quantidade maior de tecido conjuntivo pelo aspecto avermelhado intenso nesta região.

À microscopia de luz pudemos observar numerosos fibroblastos presentes no tecido conjuntivo interposto entre as fibras musculares e o tecido ósseo dos músculos de ratos adultos e com envelhecimento.

Também, nesta região de inserção das fibras musculares na superfície óssea, observamos, com a coloração Azo-Carmim, que nos dois grupos examinados existem numerosos vasos sangüíneos. O tecido conjuntivo, corado em azul, também é bem evidente e espesso na superfície do osso mandibular de ratos nos dois grupos analisados.

Analisando os capilares sangüíneos, ultraestruturalmente, notaram-se numerosas projeções citoplasmáticas, cavéolas e vesículas. Foi nitidamente evidenciado que os feixes de fibras musculares do músculo pterigóideo medial apresentam, comparativamente, diferentes diâmetros nos ratos envelhecidos e adultos.

Os resultados do presente trabalho demonstraram também que os feixes musculares apresentam-se dispostos em direção médio-lateral, de cima para baixo com inserção oblíqua, constituindo arquiteturas musculares diferentes daqueles dados estudados por alguns autores e que possuem uma inserção óssea em ângulo de noventa graus, como referido por Benjamin et al. (1986), e aspecto peniforme típico, já relatado por El Haddioui et al. (2007).

A literatura salienta que existe uma grande variação quanto aos grupamentos de fibras musculares e possivelmente de tipos de fibras, conforme 
relatados por vários autores (STEIN e PADYKULA, 1962; PADYKULA e GAUTHIER, 1967; OVALLE e SMITH, 1972; SMITH e OVALLE, 1973; FINOL e OGURA, 1977; DALL-PAI et al.,1991) que analisaram os músculos esqueléticos de ratos enevelhecidos e notaram um alto grau de polimorfismo nas fibras musculares, contendo poucas fibras atróficas e um aumento de tecido conjuntivo que constitui o endomísio. Entretanto, Layman et al. (1980) confirmaram que os músculos esqueléticos de ratos envelhecidos sofrem uma redução do número de fibras musculares.

Os nossos resultados também revelaram que os núcleos das células musculares apresentam-se de forma arredondada ou alongada com seu longo eixo paralelo às fibras musculares e localizados na periferia do sarcoplasma. Às vezes, foi notado um abaulamento na superfície do sarcolema em ratos com envelhecimento e ratos adultos. Em secção transversal, os núcleos apresentaramse em aspecto circular e esses dados são semelhantes àqueles descritos por Mcconnachie et al. (1964) e Enesco e Puddy (1964).

Por outro lado, pode-se salientar que a lâmina de sarcolema é aderida ao sarcoplasma e evidencia, nitidamente, a presença de lâmina basal perifericamente seguida de feixes de fibras colágenas do endomísio. Nossas observações ao microscópio eletrônico de transmissão demonstraram que as características ultraestruturais são perfeitamente notadas e confirmam os relatos de Merrillees (1960). Além disso, os resultados do presente estudo mostraram a disposição da rede de fibras colágenas e a lâmina basal contínua. Também em nossos dados foram evidenciadas, nos ratos envelhecidos e nos adultos, as formações de cavéolas e estruturas tubulares do sarcoplasma.

Com relação aos sarcômeros, os nossos resultados revelaram nos ratos adultos e com envelhecimento uma disposição ordenada na porção média do músculo, notando-se um pequeno desalinhamento quando se aproximavam da junção miotendínea. Yamashita et al. (2007) observaram que o alinhamento dos sarcômeros ocorre a medida que se envelhece e o desalinhamento apenas se mantém próximo à região de transmissão de forças contráteis das fibras musculares ao tecido conjuntivo. 
Em relação à porção terminal das fibras musculares, na camada profunda do tecido conjuntivo, os dados demonstraram a junção fibra muscular-tecido conjuntivo de formas variadas e uma superfície de contato com o tecido conjuntivo da superfície óssea relativamente extens. Essa característica da junção fibra muscular-tecido conjuntivo provavelmente justifica a presença de numerosas e profundas interdigitações da membrana sarcoplasmatica e lâmina basal, que foram anteriormente relatadas por Eisenberg e Milton (1984) e Souza et al. (1988) em vários músculos esqueléticos.

Também se observou que no sarcoplasma terminal das fibras musculares aparecem grupamentos de mitocôndrias como já relatado por outros autores (SOUZA et al., 1988).

Os nossos dados demonstraram que a rede de fibras colágenas do endomísio distribui-se em camadas superficiais e profundas. Na camada profunda observa-se nitidamente o trajeto das fibras colágenas em sentido longitudinal, conforme foi verificado com as cortes corados em Picrosirius e imagens obtidas através da luz polarizada, notando-se os feixes de colágenos já relatados por Kawagoe et al. (1997) durante sua observação da área de inserção muscular do pterigóideo medial na superfície óssea em humanos adultos. Semelhantemente aos dados obtidos por Kawagoe et al. (1997), pode-se notar em nossos dados, a intensa coloração do tecido colágeno, indicando a presença de colágeno tipos I e III na região das junções miotendínea e osteotendínea conforme os relatos de Junqueira et al. (1979).

Em microscopia eletrônica de transmissão, nossas amostras revelaram nitidamente a presença do endomísio envolvendo cada fibra muscular como descrito por Swatland (1987). As amostras tratadas com hidróxido de sódio para microscopia eletrônica de varredura demonstraram as características da disposição original dos feixes de fibras colágenas em aspectos tridimensionais em ambos os grupos. A rede de fibras colágenas do endomísio demarca espaços das células musculares individualmente, com aspecto semelhante ao "favo de mel" onde uma frouxa camada de fibras colágenas é evidente na superfície interna (OHTANI, 1988; NISHIMURA et al., 1994; OLIVEIRA et al., 2000). Os nossos 
dados ainda mostraram diferentes disposições dos feixes do endomísio que se relacionam à variedade de formas e diâmetros das fibras musculares. Essa variação também é notada em outros músculos de diferentes animais (NISHIMURA et al., 1996).

$\mathrm{Na}$ superfície da mandíbula, particularmente na face medial do ângulo, Azeredo et al. (1996) notaram a disposição dos feixes de fibras colágenas em variadas direções.

Em relação à junção miotendínea, em ratos adultos e com envelhecimento, os dados revelaram as interdigitações semelhantes àquelas relatadas por Kannus et al. (1992) que mencionam que estas interdigitações e seus prolongamentos emitidos encurtam com o envelhecimento, diminuindo assim a superfície de contato entre as miofibrilas e fibras colágenas.

Kojima et al. (2008) observaram que estas interdigitações aparecem com maior freqüência e maior quantidade nos músculos geradores de grande tensão. Além disso, os autores observaram que o ângulo formado entre o eixo das fibras musculares e as interdigitações varia conforme o aumento do nível de atividade muscular. Os nossos dados mostraram que existem áreas da junção miotendínea nos ratos adultos onde as interdigitações unem-se formando redes que aumentam ainda mais a superfície de contato entre as fibras tendíneas e musculares. Koijima et al. (2008) acreditam que nessas regiões a tensão muscular gerada seja maior que em outras regiões da junção miotendínea e Järvinen et al. (1991) referem que a força aplicada pelas unidades nesta superfície é reduzida, diminuindo-se o aparecimento de lesões nesta região.

Com estes dados não pretendemos ilustrar todas as características encontradas na juncão miotendínea dos musculos esqueléticos. Outros trabalhos serão necessários no futuro para demonstrar as características decorrentes das contrações musculares e de tipos de fibras musculares bem como as alterações ultraestruturais notadas na porção sarcoplasmática. 
6 CONCLUSÃO 
De acordo com os resultados obtidos no presente trabalho podemos concluir que:

1. A inserção do pterigóideo medial na face medial do ângulo da mandíbula de ratos com envelhecimento e ratos adultos junto à superfície óssea é feita através de feixes de fibras colágenas. Há uma delgada camada de fibras colágenas interligando as fibras musculares e a superfície óssea;

2. Os feixes de fibras colágenas do endomísio são notados em disposição original e "in situ", revelando-os em aspectos tridimensionais em ambos os grupos analisados;

3. Ultraestruturalmente as fibras musculares contêm sarcoplasma, núcleo periférico e sarcômeros, mitocôndrias, feixes de miofibrilas e miofilamentos com características similares tanto em ratos com envelhecimento como em adultos.

4. A junção miotendínea, tanto nos ratos com envelhecimento quanto nos ratos adultos, apresenta interdigitações entre as fibras colágenas e os feixes de miofibrilas, formando projeções que aumentam a superfície de contato desta região.

5. Qualitativamente não se observaram evidentes diferenças estruturais e ultraestruturais dos músculos pterigóideo medial de ratos adultos e com envelhecimento. 


\section{REFERÊNCIAS}

AZEREDO, R. A.; WATANABE, I.; LIBERTI, E. A.; SEMPRINI. M. The arrangement of the trabecular bone in the vestibular surface of the human fetus mandible. A scanning electron microscopy study. Bull. Assoc. Anat., v. 80, p. 7-12, 1996.

BANKS, R. W.; HARKER, D. W.; STACEY, M. J. A study of mammalian intrafusal muscle fibers using a combined histochemical and ultrastructural technique. J. Anat., v.123, p. 783-796, 1977.

BENJAMIN, M.; EVANS, E. J.; COPP, L. The histology of tendon attachments to bone in man. J. Anat., v. 149, p. 89-100, 1986.

BENJAMIN, M.; NEWELL, R. L. M.; EVANS, E. J.; RALPHS, J. R.; PEMBERTON, D. J. The structures of the insertions of the tendons of biceps brachii, triceps and brachialis in elderly dissecting room cadavers. J. Anat., v. 180, p. 327-332, 1992.

CANNON, J.G. Intrinsic and extrinsic factors in muscle aging. Ann. N. Y. Acad. Sci., v. 20, p. 72-77, 1998.

CAPLAN, A. I. The mesengenic process. Clin. Plast. Surg., v. 21, p. 429-435, 1994.

CLARK, J.; STECHSCHULTE JR, D. J. The interface between bone and tendon at an insertion site: a study of the quadriceps tendon insertion. J. Anat., v. 193, p. 605-616, 1998.

COOPER, R. R.; MISOL, S. Tendon and ligament insertion. J. Bone Joint. Surg., v. 52, p. 1-21, 1970.

DALL PAI, V.; CARMELLO, L. C. T.; DALL PAI, M. Morfologia e histoenzimologia do músculo extensor longo do hálux em ratos senis. Rev. Ciênc. Bioméd., v. 12, p. 69-78, 1991.

DYER, R. F.; ENNA, C. D. Ultrastructural features of adult human tendon. Cell Tissue Res., v. 168, p. 247-259, 1976.

EISENBERG, B. R.; MILTON, R. L. Muscle fiber termination at the tendon in the frog`s sartorius: a stereological study. Am. J. Anat., v. 171, p. 273-284, 1984.

\footnotetext{
* De acordo com:

ASSOCIAÇÃO BRASILEIRA DE NORMAS TÉCNICAS. NBR 6023: Informação e documentação: referências: elaboração. Rio de Janeiro, 2002.
} 
ENESCO, M.; PUDDY, D. Increase in the number of nuclei and weight in skeletal muscle of rats of various ages. Am. J. Anat., v. 114, p. 235-244, 1964.

FINOL, H.; OGURA, M. Estudo sobre los tipos de fibras musculares esqueléticas de la iguana. Acta Cient. Venez., v. 28, p. 213-219, 1977.

EL HADDIOUI, A.; BRAVETTI, P.; GAUDY, J. F. Anatomical study of the arrangement and attachments of the human medial pterygoid muscle. Surg. Radiol. Anat., v. 29, p. 115-124, 2007.

HEMS, T.; TILLMAN, B. Tendon entheses of the masticatory muscles. Anat. Embryol., v. 202, p. 201-208, 2000.

JÄRVINEN, M.; KANNUS, P.; KVIST, M.; ISOLA, J.; LEHTO, M.; JOZSA, L. Macromolecular composition of the myotendinous junction. Exp. Mol. Pathol., v. 55 , p. 230-237, 1991.

JÄRVINEN, T. A. H.; JOZSA, L.; KANNUS, P.; JÄRVINEN, T. L. N.; KVIST, M.; HURME, T.; ISOLA, J.; KALIMO, H.; JÄRVINEN, M. Mechanical loading regulates tenascin-c expression in the osteotendinous junction. J. Cell Sci., v. 112, p. 31573166, 1999.

JÓZSA, L.; BÁLINT, J. B.; RÉFFY, A.; DEMEL, Z. Histochemical and ultrastructural study of adult human tendon. Acta Histochem., v. 65, p. 250-257, 1979.

JUNQUEIRA, L. C.; CARNEIRO, J. Histologia básica. 8. ed. Rio de Janeiro: Guanabara-Koogan, 1995.

JUNQUEIRA, L. C. U.; VIGNOLAS, G.; BRENTANI, R. R. Picrosirius staining plus polarization microscopy, a specific method for collagen detection in tissue section. Histochem. J., v. 11, p. 447-455, 1979.

KANNUS, P. Structure of the tendon connective tissue. Scand. J. Med. Sci. Sports, v. 10, p. $312-320,2000$.

KANNUS, P.; JOZSA, L.; KVIST, M.; LEHTO, M. JÄRVINEN, M. The effect of immobilization on myotendinous junction: an ultrastructural, histochemical and immunohistochemical study. Acta Physiol. Scand., v.144, p. 387-394, 1992.

KASTELIC, J.; GALESKI, A.; BAER, E. The multicomposite structure of tendon. Connect. Tissue Res., v. 6, p. 1-23, 1978.

KAWAGOE, T.; SATO, I.; SATO, T. Distribution of macromolecular components in the muscle-bone junction of human masticatory muscles. Okajimas Folia Anat. Jpn., v. 74, p. 1-8, 1997. 
KHAN, K. M.; MAFFULLI, N.; COLEMAN, B. D.; COOK, J. L.; TAUNTON, J. E. Patellar tendinopathy: some aspects of basic science and clinical management. $\mathrm{Br}$. J. Sports Med., v. 32, p. 346-355, 1998.

KOJIMA, H.; SAKUMA, E.; MABUCHI, Y.; MIZUTAN, J.; HORIUCHI, O.; WADA, I.; HORIBA, M.; YAMASHITA, Y.; HERBERT, D. C.; SOJI, T.; OTSUKA, T. Ultrastructural changes at the myotendinous junction induced by exercise. J. Orthop. Sci., v. 13, p. 233-239, 2008.

LAYMAN, O. K.; HEGARTY, P. V. J.; SWAN, P. B. Comparison of morphological and biochemical parameters of growth in rat skeletal muscle. J. Anat. Lond., v. 130, p. 150-171, 1980.

LEXELL, J.; TAYLOR, C.C.; SJOSTROM, M. What is the cause of the ageing atrophy? Total number, size and proportion of different fiber types studied in whole vastus lateralis muscle from 15 - to 83 -year-old men. J. Neurol. Sci., v. 84 , p. 275294, 1988.

MCARDLE, A.; VASILAKI, A.; JACKSNO, M. Exercise and skeletal muscle ageing: cellular and molecular mechanisms. Ageing Res. Rev., v. 1, p. 79-93, 2002.

MCCONNACHIE, F. H.; ENESCO, M.; LEBLOND, C. P. The mode of increase in the number of skeletal muscle nuclei in the postnatal rat. Am. J. Anat., v. 114, p. 245-253, 1964.

MERRILLEES, N. C. R. The fine structure of muscle spindles in the lumbrical muscles of the rat. J. Biophys. Biochem. Cytochem., v. 7, p. 725-749, 1960.

MONTI, R. J.; ROY, R. R.; HODGSON, J. A.; EDGERTON V. R. Transmission of forces within mammalian skeletal muscles. J. Biomech., v. 32, p. 371-380, 1999.

MORIGGI, B.; KUMAI, T.; MILZ, S.; BENJAMIN, M. The structure and histopathology of the "enthesis organ" at the navicular insertion of the tendon of tibialis posterior. J. Rheumatol., v. 30, p. 508-517, 2003.

NAKAO, T. Fine structure of the myotendinous junction and "terminal coupling" in the skeletal muscle of the lamprey, Lampetra japonica. Anat. Rec., v. 182, p. 321338, 1975.

NISHIMURA, T.; HATTORI, A.; TAKAHASHI, K. Ultrastructure of the intramuscular connective tissue in bovine skeletal muscle. A demonstration using the cellmaceration/scanning electron microscope method. Acta Anat., Basel, v. 151, p. 250-257, 1994.

NISHIMURA, T.; OJIMA, K.; LIU, A.; HATTORI, A.; TAKAHASHI, K. Structural changes in the intramuscular connective tissue during development of bovine semitendinosus muscle. Tissue Cell, v. 28, p. 527-536, 1996. 
NORTON, M. W.; MEJIA, W.; MCCARTER, R. J. M. Age, Fatigue, and ExcitationContraction Coupling in Masseter Muscles of Rats. J. Gerontol. A Biol. Sci. Med. Sci., v. 56, p. B58-B65, 2001.

NORTON, M. W.; VERSTEEGDEN, A. W.; MAXWELL, L. C.; MCCARTER, R. J. Effects of age on structure and function of rat masseter muscle. FASEB J. v. 9, A651, 1995.

PADYKULA, H. A.; GAUTHIER, G. F. Ultrastructural features of three fiber types in the rat diaphragm. Anat. Rec., v. 157, p. 296-297, 1967.

PORTER, M.M.; VANDERVOORT, A.A.; LEXELL, J. Aging of human muscle: structure, function and adaptability. Scand. J. Med. Sci. Sports, v. 5, p. 129-142, 1995.

OHTANI, O. Three-dimensional organization of the connective fibers of the human pancreas: A scanning electron microscopic study of $\mathrm{NaOH}$ treated tissues. Arch. Histol. Cytol., 50, 557-566, 1987.

OHTANI, O.; USHIKI, T.; TAGUCHI, T.; KIKUTA, A. Collagen fibrillar networks as skeletal frame-works: A demonstration by cell maceration/scanning electron microscope method. Arch. Histol. Cytol., v. 51, p. 249-261, 1988.

OLIVEIRA, J. L.; IYOMASA, M. M.; MIZUSAKI, C. I.; LOPES, R. A. Morphologic study of the masseter muscle of gerbil (Meriones unguiculatus). Rev. Chil. Anat., v. 18, p. 283-286, 2000.

OVALLE, W. K.; SMITH, R. S. Histochemical identification of three types of intrafusal muscle fibers in the cat and monkey based on the myosin ATPase reaction. Can. J. Physiol. Pharmacol., v. 50, p. 195-202, 1972.

RASPANTI, M.; STROCCHI, R.; DE PASQUALE, V.; MARTINI, D.; MONTANARI, C.; RUGGERI, A. Structure and ultrastructure of the bone/ligament junction. Ital. J. Anat. Embryol., v. 101, p. 97-105, 1996.

RUFAI, A.; RALPHS, J. R.; BENJAMIN, M. Ultrastructure of fibrocartilages at the insertion of the rat achilles tendon. J. Anat., v. 189, p. 185-191, 1996.

SHEA, J. E.; HALLOWS, R. K.; RICKS, S.; BLOEBAUM, R. D. Microvascularization of the hypermineralized calcified fibrocartilage and cortical bone in the sheep proximal femur. Anat. Rec., v. 268, p. 365-370, 2002.

SMITH, R. S.; OVALLE JR, W. K. Varieties of fast and slow extrafusal muscle fibers in amphibian hind limb muscles. J. Anat., v. 116, p. 1-24, 1973. 
SMITH, L. K.; WEISS, E. L.; LEHMKUHL, L. D. Cinesiologia Clínica de Brunnstrom. 5 ed. São Paulo: Editora Manole, 1997.

SOUZA, R. R.; WATANABE, I.; MAIFRINO, L. M. The fine structure of the muscletendon junction in the rabbit. Ciência e Cultura, v. 40, p. 396-398, 1988.

STEIN, J. M.; PADYKULA, H. A. Histochemical classification of individual skeletal muscle fibers of the rat. Am. J. Anat., v. 110, p. 103-124, 1962.

SWATLAND, H. J. Fluorimetry of bovine myotendon junction by fibre-optics and microscopy of intact and sectioned tissues. Histochem. J., v. 19, p. 276-280, 1987.

TIDBALL, J. G. Myotendinous junction: morphological changes and mechanical failure associated with muscle cell atrophy. Exp. Mol. Pathol., v. 40, p. 1-12, 1984.

TROTTER, J. A.; EBERHARD, S.; SAMORA, A. Structural domains of the muscletendon junction. 1. The internal lamina and the connecting domain. Anat. Rec., v. 207, p. 573-591, 1983.

VAN EIJDEN, T. M. G. J.; KORFAGE, J.A.M.; BRUGMAN, P. Architecture of the human jaw-closing and jaw-opening muscles. Anat. Rec., v. 248, p. 464-474, 1997.

VIIDIK, A. Functional properties of collagenous tissues. Int. Rev. Connect. Tissue Res., v. 6, p. 127-215, 1973.

WARREN, R.A.; KAY, N.R.; NORRIS, S.H. The microvascular anatomy of the distal digital extensor tendon. J. Hand Surg., v. 13, p. 161-3, 1988. 